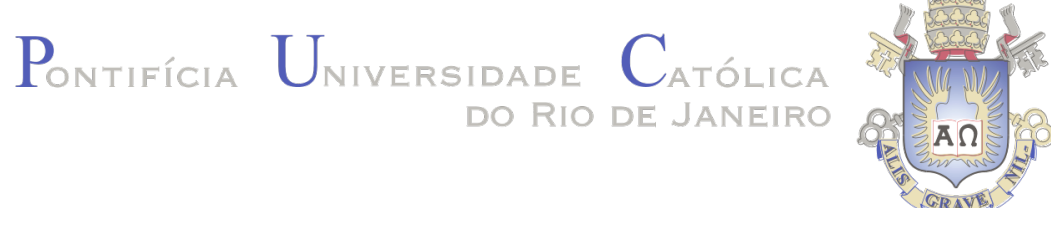

Verônica Barbosa Mazza

\title{
Otimização de processo para produção \\ do coagulante sulfato férrico pela oxidação de sulfato ferroso com peróxido de
hidrogênio de sulfato ferroso com peróxido de
hidrogênio
} (1)

\author{
Dissertação de Mestrado
}

Dissertação apresentada como requisito parcial para obtenção do grau de Mestre pelo Programa de Pós-graduação em Engenharia de Materiais e de Processos Químicos e Metalúrgicos do departamento de Engenharia Química e de Materiais da PUC-Rio.

Orientadores: Prof. Luiz Alberto Cesar Teixeira Prof. a Ana Rosa Fonseca de Aguiar Martins 


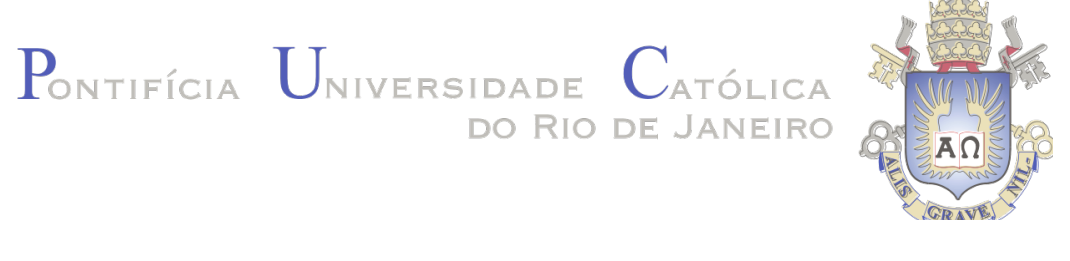

Verônica Barbosa Mazza

\section{Otimização de processo para produção do coagulante sulfato férrico pela oxidação de sulfato ferroso com peróxido de hidrogênio}

Dissertação apresentada como requisito parcial para obtenção do grau de Mestre pelo Programa de Pós-graduação em Engenharia de Materiais e de Processos Químicos e Metalúrgicos do departamento de Engenharia Química e de Materiais da PUC-Rio. Aprovada pela Comissão Examinadora abaixo assinada.

Prof. Luiz Alberto Cesar Teixeira Orientador

Departamento de Engenharia Química e de Materiais - PUC-Rio

Prof. a Ana Rosa Fonseca de Aguiar Martins Coorientadora

Departamento de Engenharia Química e de Materiais - PUC-Rio

Prof. ${ }^{a}$ Lídia Yokoyama

Departamento de Processos Inorgânicos - UFRJ

Prof. Brunno F. Santos

Departamento de Engenharia Química e de Materiais - PUC-Rio 
Todos os direitos reservados. É proibida a reprodução total ou parcial do trabalho sem autorização da universidade, da autora e do orientador.

\section{Verônica Barbosa Mazza}

Graduada em Engenharia Química pela Pontifícia Universidade Católica do Rio de Janeiro (Rio de Janeiro, RJ, Brasil). Técnica em Informática pelo Colégio Pedro Segundo (Rio de Janeiro, RJ, Brasil).

Ficha Catalográfica

Mazza, Verônica Barbosa

Otimização de processo para produção do coagulante sulfato férrico pela oxidação de sulfato ferroso com peróxido de hidrogênio / Verônica Barbosa Mazza ; orientadores: Luiz Alberto Cesar Teixeira, Ana Rosa Fonseca de Aguiar Martins. - 2019.

103 f. : il. color. ; $30 \mathrm{~cm}$

Dissertação (mestrado)-Pontifícia Universidade Católica do Rio de Janeiro, Departamento de Engenharia Química e de Materiais, 2019. Inclui bibliografia

1. Engenharia Química e de Materiais - Teses. 2. Coagulante férrico. 3. Sulfato férrico. 4. Peróxido de hidrogênio. 5. Otimização. 6. Processo. I. Teixeira, Luiz Alberto Cesar. II. Martins, Ana Rosa Fonseca de Aguiar. III. Pontifícia Universidade Católica do Rio de Janeiro. Departamento de Engenharia Química e de Materiais. IV. Título. 


\section{Agradecimentos}

Aos meus pais, Virgílio e Edmar, minha base e meus exemplos de vida; para quem dedico todas as minhas vitórias.

Ao Pietro, meu namorado e melhor amigo, pela paciência e carinho.

À Pontifícia Universidade Católica, por me acolher em mais uma etapa da minha construção acadêmica e pessoal.

Aos meus orientadores, Professor Luiz Alberto Cesar Teixeira e Professora Ana Rosa Fonseca de Aguiar Martins, pela amizade, pelos ensinamentos e pela confiança em mim depositada.

À Peróxidos do Brasil Ltda. (Grupo Solvay), pelo apoio laboratorial ao meu projeto de Mestrado.

Ao Conselho Nacional de Desenvolvimento Científico e Tecnológico (CNPq) pelo apoio financeiro.

O presente trabalho foi realizado com apoio da Coordenação de Aperfeiçoamento de Pessoal de Nível Superior - Brasil (CAPES) - código de financiamento 001.

Em especial ao Prof. Brunno F. dos Santos, por toda a compreensão, intercâmbio de ideias e colaboração na elaboração deste trabalho.

Ao Ronald Rojas, ao técnico Henrique Meira, a Naira de Oliveira, a Fernanda Martins e a todos os integrantes da Casa XXI, por toda a assistência dada no desenvolvimento do projeto. 


\section{Resumo}

Mazza, Verônica Barbosa; Teixeira, Luiz Alberto Cesar; Martins; Ana Rosa Fonseca de Aguiar. Otimização de processo para produção do coagulante sulfato férrico pela oxidação de sulfato ferroso com peróxido de hidrogênio. Rio de Janeiro, 2019, 103 p. Dissertação de Mestrado Departamento de Engenharia Química e de Materiais, Pontifícia Universidade Católica do Rio de Janeiro.

Sabe-se que o coagulante sulfato férrico pode ser obtido através da reação de oxidação entre sulfato ferroso e peróxido de hidrogênio em meio ácido. Porém, o método conhecido de obtenção deste coagulante em escala industrial utilizando o peróxido de hidrogênio como agente oxidante não proporciona condições economicamente atrativas, frente aos demais processos. Este potente agente oxidante sofre forte influência da temperatura e da presença de íons ferro no seu processo de auto decomposição em água e oxigênio. Pode-se considerar que as condições do meio reacional, na etapa de adição do agente oxidante, são os fatores determinantes para a produção do coagulante férrico com o maior aproveitamento do peróxido de hidrogênio adicionado. O presente trabalho teve como objetivo investigar as condições necessárias para a produção do coagulante férrico utilizando o peróxido de hidrogênio, em um processo economicamente competitivo. A pesquisa foi fundamentada nas técnicas de planejamento de experimentos e otimização de processos. A modelagem matemática do processo possibilitou a definição da magnitude dos parâmetros a serem utilizados otimizando o processo e a especificação das características desejadas do produto final. As variáveis independentes estudadas na modelagem matemática foram: temperatura (7,5 $\left.27,5^{\circ} \mathrm{C}\right)$, quantidade de peróxido de hidrogênio $(100-300 \%)$ referente à sua quantidade estequiométrica e a diluição do meio utilizando água (100 - $300 \%)$ referente à sua quantidade estequiométrica. As quantidades estequiométricas dos reagentes foram determinadas visando ao atingimento das especificações de um coagulante férrico comercial. O modelo desenvolvido foi sobre a Conversão de $\mathrm{Fe}^{2+}$ em $\mathrm{Fe}^{3+}(\%)$ e avaliado através da Análise da Variância (ANOVA). As condições ótimas escolhidas para o ponto ótimo foram: temperatura igual a $17,5^{\circ} \mathrm{C}, 150 \%$ da quantidade estequiométrica de peróxido de hidrogênio e $200 \%$ da quantidade estequiométrica de água. A resposta da etapa de otimização indicou uma conversão de $96,17 \%$ de $\mathrm{Fe}^{2+}$ em $\mathrm{Fe}^{3+}$, resultando em um coagulante dentro dos padrões especificados por norma técnica. O modelo matemático obtido previu uma conversão de $96,13 \%$ de $\mathrm{Fe}^{2+}$ em $\mathrm{Fe}^{3+}$, resultando em um erro percentual de 0,043\% entre o resultado predito pelo modelo matemático e o resultado experimental. As análises 
das superfícies de resposta e da quantidade de peróxido de hidrogênio residual em solução indicaram que o controle do processo em baixas temperaturas contribui para o melhor aproveitamento do peróxido de hidrogênio na conversão de $\mathrm{Fe}^{2+} \mathrm{em} \mathrm{Fe}^{3+}$, devido à desaceleração da auto decomposição incitada pelo fator temperatura. A análise do potencial de redução ao longo da reação em função do perfil de conversão mostrou que conversões acima de $90 \%$ de $\mathrm{Fe}^{2+}$ em $\mathrm{Fe}^{3+}$ apresentaram potencial redox $\left(E_{h}\right)$ correspondente acima de 0,70 Volts, indicando a possibilidade da utilização deste parâmetro no controle da conversão em processos industriais.

\section{Palavras-chave}

Coagulante férrico; sulfato férrico; sulfato ferroso; peróxido de hidrogênio; processo; otimização. 


\section{Abstract}

Mazza, Verônica Barbosa; Teixeira, Luiz Alberto Cesar (Advisor); Martins; Ana Rosa Fonseca de Aguiar (Co-Advisor). Process optimization for the production of ferric sulfate coagulant by the oxidation of ferrous sulfate with hydrogen peroxide. Rio de Janeiro, 2019, 103 p. MSc. Dissertation Department of Chemical and Materials Engineering, Pontifical Catholic University of Rio de Janeiro.

It is known that the coagulant ferric sulfate can be obtained by the oxidation reaction of ferrous sulfate with hydrogen peroxide in acidic medium. However, the known method of obtaining this coagulant on an industrial scale using hydrogen peroxide as an oxidizing agent do not provide economically attractive conditions compared to other processes. This potent oxidizing agent undergoes strong influence of the temperature and the presence of iron ions in its process of self-decomposition in water and oxygen. It can be considered that the conditions of the reaction medium in the step of adding the oxidizing agent are the determining factors for the production of the ferric coagulant with the greatest use of the added hydrogen peroxide. The present work had the objective of investigating the necessary conditions for the production of the ferric coagulant using the hydrogen peroxide as an economically competitive process. The research was based on the techniques of factorial design and process optimization. The mathematical modeling of the process allowed the definition of the magnitude of the parameters to be used, optimizing the process and specifying the desired characteristics of the final product. The independent variables studied in the mathematical modeling were: temperature $\left(7,5-27,5^{\circ} \mathrm{C}\right)$, amount of hydrogen peroxide (100-300\%) relative to its stoichiometric amount, and dilution of the medium using water (100-300\%) relative to its stoichiometric amount. The stoichiometric quantities of the reactants were determined in order to reach the specifications of a commercial ferric coagulant. The model developed was on Conversion of $\mathrm{Fe}^{2+}$ to $\mathrm{Fe}^{3+}(\%)$ and evaluated through Analysis of Variance (ANOVA). The optimum conditions chosen for the optimum were: temperature equal to $17,5^{\circ} \mathrm{C}$, $150 \%$ of the stoichiometric amount of hydrogen peroxide and $200 \%$ of the stoichiometric amount of water. The optimization of the response surfaces indicated a conversion of $96.17 \% \mathrm{Fe}^{2+}$ to $\mathrm{Fe}^{3+}$, resulting in a coagulant within the characteristics specified by the technical standard. The obtained mathematical model predicted a conversion of $96.13 \% \mathrm{Fe}^{2+}$ to $\mathrm{Fe}^{3+}$, resulting in a percentage error of $0,043 \%$ between the predicted results by the mathematical model and the experimental results. The analysis of the response surfaces and the amount of residual hydrogen peroxide in solution indicated that the control of the process at low temperatures contributes to 
the better utilization of the hydrogen peroxide in the conversion of $\mathrm{Fe}^{2+}$ into $\mathrm{Fe}^{3+}$, due to the deceleration of the self-induced decomposition by the factor temperature. The analysis of the reduction potential along the conversion profile function showed that conversions above $90 \%$ of $\mathrm{Fe}^{2+}$ into $\mathrm{Fe}^{3+}$ presented a corresponding redox potential (Eh) above 0,70 Volts, indicating the possibility of using this parameter for the control of conversion into industrial processes.

\section{Keywords}

Ferric coagulant; ferric sulfate; ferrous sulfate hydrogen peroxide; proces; optimization. 


\section{Sumário}

1 Introdução

2 Objetivos

2.1. Objetivos gerais 19

2.2. Objetivos específicos 19

3 Revisão Bibliográfica $\quad 20$

3.1. Coagulantes e Floculantes 20

3.1.1. Tratamento de água e efluentes 20

3.1.2. Material em suspensão e coloidal 21

3.1.3. Coagulação 23

3.1.4. Floculação $\quad 24$

3.1.5. Coagulantes $\quad 25$

3.1.6. Floculantes $\quad 29$

3.2. Sulfato férrico 29

3.2.1. Características físicas e requisitos físicos e químicos para a utilização do sulfato férrico para tratamento de águas e efluentes 31

3.2.2. Requisitos físicos 31

3.2.3. Requisitos Químicos 31

3.2.4. Impurezas 32

3.2.5. Métodos de produção de Sulfato Férrico 32

3.2.6. Princípios necessários na produção de sulfato férrico 35

3.3. Peróxido de Hidrogênio 36

3.3.1. Contexto histórico e produção atual 36

3.3.2. Aplicação do Peróxido de Hidrogênio 37

3.3.3. Decomposição do Peróxido de Hidrogênio 39

3.3.3.1. Fatores que afetam a decomposição do peróxido de hidrogênio 41

3.3.3.2. Auto Decomposição Error! Bookmark not defined.

3.3.3.3. Decomposição Catalisada por Metais 42

3.3.3.4. Decomposição na presença de Sulfato 43

3.4. Planejamento de Experimentos 44

3.4.1. Princípios básicos de planejamento e otimização de Processos 44 
4 Materiais e Métodos $\quad 48$

4.1. Materiais 48

4.1.1. Sistema para controle de oxidação e temperatura 48

4.1.2. Equipamentos analíticos $\quad 50$

4.1.3. Reagentes 50

4.2. Métodos 51

4.2.1. Produção de sulfato férrico 51

4.2.2. Caracterização do coagulante sulfato férrico produzido 53

4.2.2.1. Quantificação de $\mathrm{Fe}^{2+} \quad 53$

4.2.2.2. Quantificação de $\mathrm{Fe}_{\text {total }} \quad 54$

4.2.3. Quantificação de peróxido de hidrogênio residual 54

4.2.4. Conceitos gerais aplicados em análises estatísticas e metodologia estatística para tomada de decisões $\quad 54$

5 Resultados e Discussão $\quad 58$

5.1. $1^{\text {a }}$ Etapa - Seleção de Variáveis $\quad 58$

5.2. Otimização do processo 64

5.2.1. Discussão físico química das superfícies de resposta e curvas de contorno 76

5.3. Análise da conversão de $\mathrm{Fe}^{2+}$ em $\mathrm{Fe}^{3+}$ em função da quantidade de peróxido de hidrogênio

5.4. Análise da conversão de $\mathrm{Fe}^{2+} \mathrm{em} \mathrm{Fe}^{3+}$ e do potencial de redução em função da quantidade de peróxido de hidrogênio

5.5. Análise do perfil de potencial de oxidação (Eh) e diagrama de Pourbaix

6 Conclusões

9.1. Reações envolvidas na decomposição catalisada por metais $\quad 100$

9.2. Respostas obtidas pelo software Statistica 
9.2.1. Estimação dos Efeitos, incluindo todas as variáveis estudadas 101

9.2.2. Regressão dos coeficientes - Variáveis não codificadas 102

9.3. Fotos das soluções para verificação da estabilidade do produto. 102

9.4. $\mathrm{pH}$ final médio de cada ensaio 103 


\section{Lista de figuras}

Figura 1 - Comportamento das partículas coloidais.

Figura 2 - Principais espécies hidrolisadas de coagulantes a base de alumínio e ferro com centros metálicos trivalentes.

Figura 3 - Mecanismos de coagulação com coagulante férrico.

Figura 4 - Reação de dismutação do peróxido de hidrogênio.

Figura 5 - Estratégia sequencial para tomadas de decisões.

Figura 6 - Etapas de um Planejamento Experimental e Otimização de Processos.

Figura 7 - Esquematização de um DCCR com 3 fatores.

Figura 8 - Sistema montado em bancada para controle de temperatura e oxidação.

Figura 9 - Cristal de sulfato ferroso formado.

Figura 11 - Valores observados versus valores previsto da conversão de $\mathrm{Fe}^{+2}$ em Fe ${ }^{+3}$ obtido pelo software Statistica

Figura 12 - Superfície de resposta e curvas de contorno para o parâmetro conversão de $\mathrm{Fe}^{+2}$ em $\mathrm{Fe}^{+3}$ em função da adição de peróxido de hidrogênio e água ao processo, na temperatura operacional igual a $17,5^{\circ} \mathrm{C}$.

Figura 13 - Superfície de resposta e curvas de contorno para o parâmetro conversão de $\mathrm{Fe}^{+2}$ em $\mathrm{Fe}^{+3}$ em função da adição de peróxido de hidrogênio e faixa de temperatura operacional, com adição de $200 \%$ do valor estequiométrico de água ao processo.

Figura 14 - Superfície de resposta e curvas de contorno para o parâmetro conversão de $\mathrm{Fe}^{+2}$ em $\mathrm{Fe}^{+3}$ em função da faixa de temperatura operacional e da adição de água ao processo, com adição de $200 \%$ do valor estequiométrico de peróxido de hidrogênio ao processo.

Figura 15 - \% Convertida de $\mathrm{Fe}^{+2}$ em $\mathrm{Fe}^{+3}$ versus adição de peróxido de hidrogênio no meio reacional.

Figura 16 - Variabilidade da resposta de conversão.

Figura 17 - Influência da temperatura pelo perfil de conversão de $\mathrm{Fe}^{+2}$ em $\mathrm{Fe}^{+3}$ na condição operacional de diluição equivalente a $200 \%$ da quantidade estequiométrica de água.

Figura 18 - Influência da diluição no perfil de conversão de $\mathrm{Fe}^{+2} \mathrm{em} \mathrm{Fe}^{+3}$ na condição operacional de temperatura equivalente a $17,5^{\circ} \mathrm{C}$. 
Figura 19 - Perfil de conversão de $\mathrm{Fe}^{+2}$ em Fe ${ }^{+3}$ na condição operacional em igual temperatura $\left(12,5^{\circ} \mathrm{C}\right.$ e $\left.22,5^{\circ} \mathrm{C}\right)$ e em diferentes diluições $(150 \% \mathrm{e}$ $250 \%$ de água).

Figura 20 - Perfil de conversão de $\mathrm{Fe}^{+2} \mathrm{em} \mathrm{Fe}^{+3}$ na condição operacional de igual diluição (150\% e 250\% de água) em diferentes temperaturas de operação $\left(12,5^{\circ} \mathrm{C}\right.$ e $\left.22,5^{\circ} \mathrm{C}\right)$.

Figura 21 - Conversão de $\mathrm{Fe}+2$ em Fe+3 e potencial de redução em função da quantidade adicionada de peróxido de hidrogênio nas diferentes condições experimentais.

Figura 22 - Diagrama de Pourbaix para a família de espécies de Fe e S em água.

Figura 23 - Eh (V) versus conversão em cada ensaio. 92

Figura 24 - Perfil dos efeitos todos os fatores.

Figura 25 - Perfil dos efeitos com retirada do fator de interação $\mathrm{H}_{2} \mathrm{O}_{2}(L) x$ Temp. (L).

Figura 26 - Perfil dos efeitos com retirada do fator de interação $\mathrm{H}_{2} \mathrm{O}_{2}(L) x$ $\mathrm{H}_{2} \mathrm{O}(\mathrm{L})$.

Figura 27 - Perfil dos efeitos com retirada do fator $\mathrm{H}_{2} \mathrm{O}(\mathrm{Q})$.

Figura 28 - Perfil dos efeitos com retirada do fator Temperatura (Q). 102

Figura 29 - Perfil dos efeitos com retirada do fator $\mathrm{H}_{2} \mathrm{O}_{2}(Q)$. 102

Figura 30 - Perfil de regressão com os fatores significativos.

Figura 31 - Soluções coagulante referentes aos ensaios 1, 2 e 3.

Figura 32 - Soluções coagulante referentes aos ensaios 4, 5 e 6.

Figura 33 - Soluções coagulante referentes aos ensaios 7, 8 e 9.

Figura 36 - Soluções coagulante referentes aos ensaios 13, 14 e 15.

Figura 35 - Soluções coagulante referentes aos ensaios 16 e 17.

Figura 34 - Soluções coagulante referentes aos ensaios 10, 11 e 12. 


\section{Lista de tabelas}

Tabela 1- Classificação das partículas pelo tamanho.

Tabela 2 - Coagulantes mais comumente utilizados a base de ferro e de alumínio.

Tabela 3 - Poder relativo de coagulação de diferentes eletrólitos.

Tabela 4 - Campos de aplicação do peróxido de hidrogênio.

Tabela 5 - Espécies Oxidantes e respectivos potencias de oxidação.

Tabela 6 - Valor de a em função do número de fatores.

Tabela 7 - Especificações dos componentes do sistema montado em bancada.

Tabela 8 - Níveis utilizados na primeira triagem das variáveis.

Tabela 9 - Valores codificados e respostas da eficiência na redução

e estabilidade na primeira triagem de variáveis.

Tabela 10 - Níveis utilizados na segunda triagem das variáveis.

Tabela 11 - Valores codificados e respostas da eficiência na redução e estabilidade na segunda triagem de variáveis.

Tabela 12 - Fatores, códigos e níveis do experimento realizado.

Tabela 15 - Coeficientes de determinação $R^{2}$ e $R^{2}$ ajustado.

Tabela 16 - Coeficientes de Regressão.

Tabela 17 - ANOVA.

Tabela 18 - Percentuais mássicos de $\mathrm{Fe}^{2+}$ e $\mathrm{Fe}^{3+}$ e a análise de estabilidade dos coagulantes férricos produzidos em cada ensaio.

Tabela 19 - Conversão mínima requerida para cada ensaio.

Tabela 20 - Condições operacionais utilizadas no ensaio experimental para validação do modelo.

Tabela 21 - Resultados preditos e observados obtidos nas condições otimizadas do processo e erro percentual. 


\title{
Lista de abreviaturas
}

\author{
ANOVA - Análise da Variância \\ atm - Pressão atmosférica \\ ETA - Estação de Tratamento de Água \\ ECF - Elemental Chlorine Free \\ Eh - Potencial de Oxirredução \\ DCCR - Delineamento Composto Central Rotacional \\ OMS - Organização Mundial De Saúde \\ pH - Potencial Hidrogeniônico \\ Ppm - Partes por milhão \\ TCF - Total Chlorine Free \\ UNEP - United Nations Environment Programme
}


Quelli che s'innamorano della pratica senza la scienza, sono come i nocchieri che entrano in naviglio senza timone o bussola, che mai hanno certezza dove si vadano. 


\section{1}

\section{Introdução}

O modelo de desenvolvimento econômico originado no século XX promoveu a escassez de recursos naturais e a contaminação excessiva do meio ambiente, desenhando um cenário de crise ambiental em nível mundial. Esta prática de desenvolvimento econômico a todo custo é baseada no alto consumo de matériasprimas, levando as reservas de recursos naturais à exaustão, e no descarte de poluentes no meio ambiente acima da capacidade de absorção pelos ecossistemas.

O cenário atualmente vivenciado de crise ambiental e a projeção do impacto dos danos ambientais nas futuras gerações evidenciaram a necessidade da participação da sociedade como um todo na desaceleração do processo de degradação ambiental, gerando um movimento que promoveu grandes transformações no cenário econômico mundial.

As exigências de uma economia globalizada pressionaram as empresas a adequarem os seus sistemas de produção a um modelo de desenvolvimento sustentável. Para a conservação do desenvolvimento das empresas mantendo a competitividade e a lucratividade, foi necessário que estas investissem no desenvolvimento de métodos de produção mais eficientes, com menor geração de poluentes e que utilizem materiais que representem menores riscos ao meio ambiente.

Apesar dos inegáveis avanços no desenvolvimento de tecnologias e métodos de produção com menores impactos ao meio ambiente, ainda hoje sofremos com as consequências de ações que causam a degradação ambiental. Os recursos hídricos, um dos mais importantes recursos naturais para a manutenção da vida e um exemplo de recurso utilizado nas mais diversas atividades, tem apresentado uma contínua queda na sua quantidade em termos de qualidade.

De acordo com a OMS (Organização Mundial De Saúde), o fornecimento de água deve ser adequado, seguro e acessível a todos (1). Porém, este recurso continua sendo degradado. Estima-se que cerca de 2,2 bilhões de pessoas no mundo não possuam acesso à água própria para consumo em suas casas, causando a esta grande parcela da população um número significativo de doenças 
(2). De acordo com o relatório da UNEP (2010), o número de mortes causadas pelo consumo de água poluída é superior ao número mortes causadas por todas as formas de violência, incluindo guerras (3).

A baixa qualidade da água bruta disponível para consumo humano pode acarretar na necessidade de um maior consumo de produtos químicos em seus processos de tratamento (4). Diante desta problemática, torna-se indispensável investimentos voltados para a inovação dos métodos de produção dos agentes químicos utilizados nos processos de tratamento de águas, em busca de métodos mais eficientes e coerentes com as necessidades atuais.

Atualmente as Estação de Tratamento de Água (ETA) são compostas por uma sequência de operações unitárias que combinadas promovem a obtenção de grandes volumes de água tratada e segura para o abastecimento público e, portanto, atendendo aos critérios físico-químicos e microbiológicos definidos pelas agências reguladoras (5) (6). Uma das etapas mais importantes para garantir a obtenção de água segura para o consumo consiste no processo de coagulação, a qual é obtida através da adição de um agente químico dito coagulante.

O sulfato férrico é um agente coagulante de alta eficiência e de rápida hidrolise, quando adicionado em água. Atualmente o método de produção mais conhecido deste agente químico coagulante consiste na oxidação de sulfato ferroso em meio ácido e em condições de altas temperaturas e sob pressão, resultando em um processo complexo e de alto custo. Sabe-se da eficiência do peróxido de hidrogênio aplicado em processos de oxidação para a conversão de ferro (II) em ferro (III), porém o método de produção industrial do coagulante férrico que utiliza como agente oxidante o peróxido de hidrogênio, em domínio público, apresenta um processo altamente dispendioso, inviabilizando a produção do coagulante utilizando este reagente, frente aos demais métodos de produção.

Tendo em vista a alta eficiência do peróxido de hidrogênio e por este representar um reagente ambientalmente atraente, no presente trabalho foram estudadas as condições operacionais para a otimização da obtenção do coagulante sulfato férrico dentro dos padrões exigidos comercialmente utilizando o peróxido de hidrogênio como agente oxidante.

A otimização do processo foi obtida pelo emprego de técnicas de planejamento fatorial de experimentos. As ferramentas de análise estatística foram empregadas devido a eficiência que estas apresentam na descrição do comportamento integrado das variáveis envolvidas no processo e o seu crucial desempenho na redução de custos e tempo, na busca da maximização da produtividade e do rendimento de um processo 


\section{2}

\section{Objetivos}

O objetivo geral do presente trabalho foi a otimização da produção de uma solução coagulante de sulfato férrico a partir de cristais de sulfato ferroso em meio ácido, utilizando como agente oxidante o peróxido de hidrogênio.

\section{1.}

\section{Objetivos gerais}

- Verificar a factibilidade da maximização da conversão de sulfato ferroso em sulfato férrico com a adição de menores quantidades de peróxido de hidrogênio através do controle da temperatura do meio reacional em uma faixa de baixas temperaturas.

- Modelar e otimizar o processo de produção do coagulante sulfato férrico, mantendo a condição otimizada dentro dos padrões prédeterminados para coagulantes comerciais.

\section{2 .}

\section{Objetivos específicos}

- Estudar o efeito das variáveis do processo, como: quantidade de peróxido de hidrogênio; de ácido sulfúrico; de água adicionados, em função do valor estequiométrico e temperatura.

- Avaliar as respostas do processo com relação à Conversão de $\mathrm{Fe}^{2+}$ em $\mathrm{Fe}^{3+}(\%)$.

- Avaliar a solução de sulfato férrico produzida, verificando seu enquadramento nas especificações técnicas e comerciais vigentes.

- Construir superfícies de respostas e curvas de nível a partir do modelo matemático desenvolvido, com o intuito de estipular os valores ótimos de operação dos parâmetros avaliados no processo.

- Investigar o comportamento de conversão através do potencial de oxirredução $\left(E_{h}\right)$. 


\section{3 \\ Revisão Bibliográfica}

\section{1.}

\section{Coagulantes e Floculantes}

Visto que, o objetivo do presente trabalho consiste na obtenção do coagulante sulfato férrico, utilizado em tratamento de águas, serão abordados nos próximos tópicos os aspectos que envolvem a utilização e produção deste agente químico para o sistema de tratamento de águas e efluentes e os conceitos mais significativos sobre o sistema coloidal e o fenômeno da coagulação e floculação.

\subsection{1.}

\section{Tratamento de água e efluentes}

A aplicação de métodos de tratamento para obtenção água potável vem sendo praticada pelo homem há milhares de anos. Existem registros que demonstram que em 1500 a.C. os egípcios já utilizavam o fenômeno da coagulação e floculação para o assentamento de partículas suspensas, através da aplicação de alume (6).

O processo de coagulação-floculação pode ser aplicado como um pré ou pós-tratamento de efluentes, sendo independente da origem do efluente e do esquema geral da planta de tratamento aplicado. Este mecanismo para retirada de particulados e/ou coloides pertence a uma cadeia de operações, que precede os processos de decantação e ou flotação e da filtração. Pode-se afirmar que o desempenho global do tratamento está intrinsicamente ligado à eficiência do processo de coagulação-floculação (7).

Atualmente, tanto a água potável para consumo humano quanto a de efluentes de descarte necessitam atender a padrões, determinados por leis, a fim de garantir a sua potabilidade e conformidade aos padrões exigidos, antes da sua distribuição e descarte respectivamente (8) (9).

A etapa de coagulação/floculação é largamente aplicada nas plantas de tratamento de águas e efluentes de descarte devido à sua alta eficiência na remoção de diferentes partículas, atrelada à simplicidade do processo e ao baixo custo dos reagentes químicos utilizados. Usualmente, esta etapa é empregada 
visando à remoção/separação de coloides e partículas suspensas, podendo ser de matéria orgânica natural ou inorgânica. Para o tratamento de águas residuais, suas funcionalidades adicionais incluem a remoção de metais tóxicos, ânions, cor, odor, entre outros (10).

\subsection{2.}

\section{Material em suspensão e coloidal}

A erosão de mananciais, dissolução de minerais, decaimento da vegetação e o descarte de efluentes industriais e domésticos, acarretam na deposição de diversos materiais nos corpos d'água, sendo estas as principais causas da presença de materiais sólidos suspensos em água (10). Estes materiais podem ser orgânicos (os quais possuem potencial para a formação de subprodutos carcinogênicos), inorgânico (ex. cobre, mercúrio, arsênico e fósforo), microrganismos patogênicos (ex. protozoário Cryptosporidium e vírus), podem gerar a coloração e turbidez da água e atuar como meio de transporte para substâncias tóxicas. A presença destes materiais faz evidente a necessidade de sua remoção para que a água esteja em conformidade com a sua destinação.

Analisando a Tabela 1, pode-se observar que quanto menor o tamanho de uma dada partícula, maior será o seu tempo de deposição. O processo de coagulação é utilizado para a remoção do material particulado e em especial do particulado coloidal, devido ao consumo excessivo de tempo para sua sedimentação e por passarem com facilidade pelos meios filtrantes, inviabilizando a remoção por tratamentos físicos convencionais (11). 
Tabela 1- Classificação das partículas pelo tamanho.

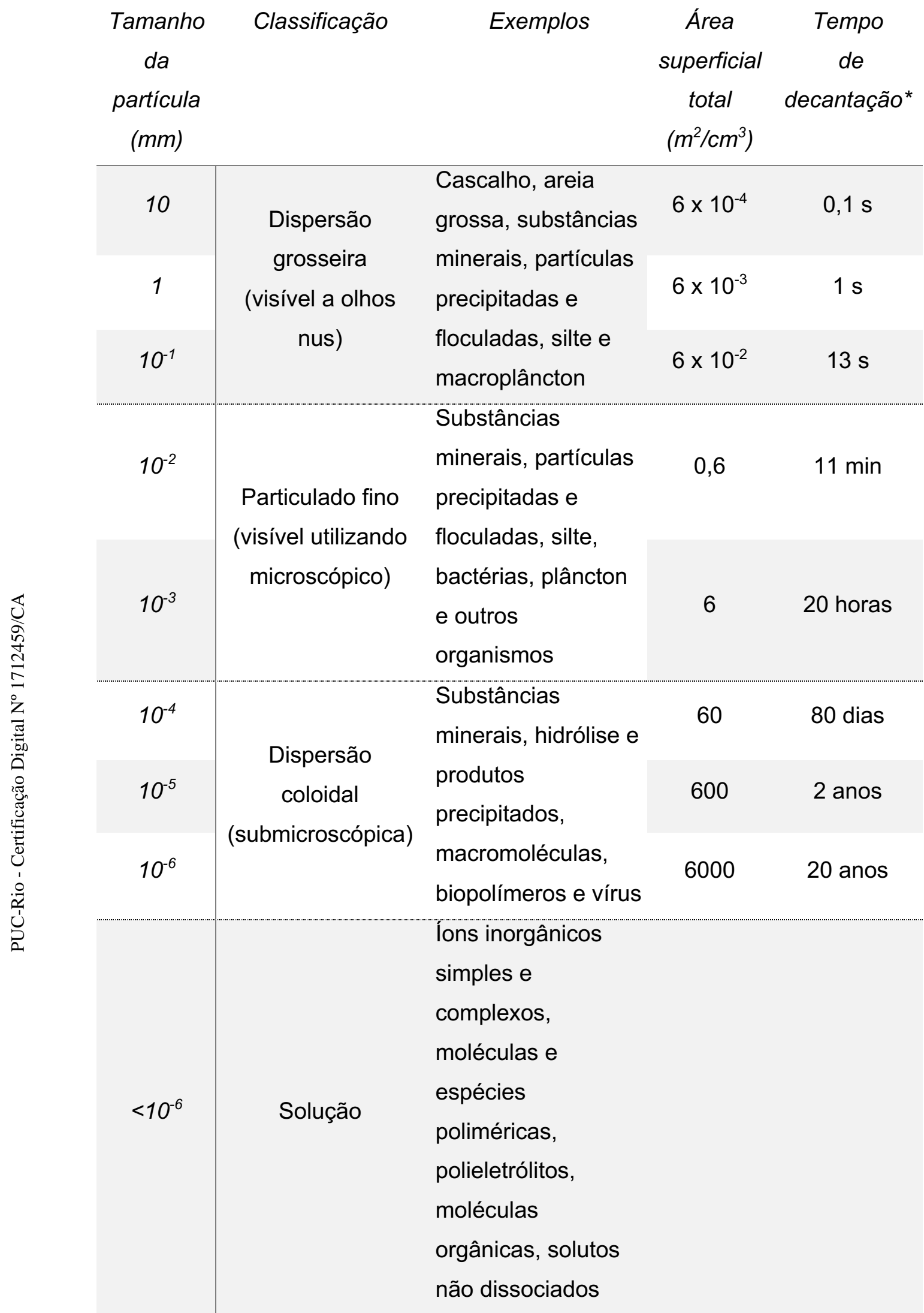

Nota: *Tempo requerido para decantação de $100 \mathrm{~mm}$, caso gravidade específica seja igual a 2,65. Fonte: Adaptado de Bratby,1980 (10). 
A estabilidade em suspensão das partículas coloidais é gerada devido à sobreposição de forças associadas a interface sólido-líquido, que impedem a sua aglutinação e mantem estas partículas em um estado de dispersão. As principais forças que promovem a estabilidade da dispersão coloidal possuem origem na presença de uma carga superficial na interface entre a partícula coloidal e o líquido e a camada de hidratação superficial (12).

Analisando a Tabela 1 observa-se que quanto menor o tamanho da partícula maior será a sua área superficial, tornando mais dominante a influência do fenômeno associado às interfaces e consequentemente a diminuição dos efeitos gerados pela gravidade (13).

Todos os coloides possuem cargas elétricas em sua superfície. A presença da carga elétrica primária pode ser gerada por dissociações que ocorrem na superfície das moléculas contidas na estrutura da micela do coloide ou pela adsorção de íons presentes na água. O coloide tem a capacidade de adsorver íons de forma seletiva e esta capacidade é provida devido ao fato desta partícula possuir uma extensa área superficial exposta ao meio. Grande parte das partículas coloidais apresentam carga negativa em meios com pH ente 5 e 10, faixa na qual a grande maioria das águas naturais se encontra (14) (15).

Após o coloide adquirir a sua carga elétrica primária, contraíons são atraídos à sua superfície, levando a formação de um campo eletroestático de carga contrária à sua carga primária. Este campo eletroestático gera forças repulsivas entre as partículas coloidais de cargas iguais, resultando no impedimento da agregação das partículas, e assim, implicando em um longo período de tempo para que ocorra a sedimentação, como mostrado na Tabela 1.

Portanto, para que seja possível promover a agregação das partículas coloidais e consequentemente a sua deposição, primeiramente é necessário que haja a desestabilização da dispersão, sendo isto possível através do processo de coagulação.

\subsection{3. \\ Coagulação}

"A coagulação é o processo pelo qual a desestabilização de uma dada suspensão ou solução é efetuada. Ou seja, a função da coagulação é superar os fatores que promovem a estabilidade de um dado sistema." (10)

Durante a operação de mistura rápida distribui-se o agente coagulante de forma homogênea por toda massa de água a ser tratada. Imediatamente após a 
inserção do agente coagulante solúvel no efluente ocorre a hidrólise do mesmo em partículas carregadas com carga contrária à dos coloides presentes em solução, gerando uma mudança nas propriedades físico-químicas da dispersão.

Este fenômeno promove a anulação da carga das partículas coloidais permitindo a formação dos coágulos. Portanto, este processo unitário consiste na geração de um estado de desequilíbrio eletrostático, ocasionado pela reação do coagulante com as partículas coloidais (16).

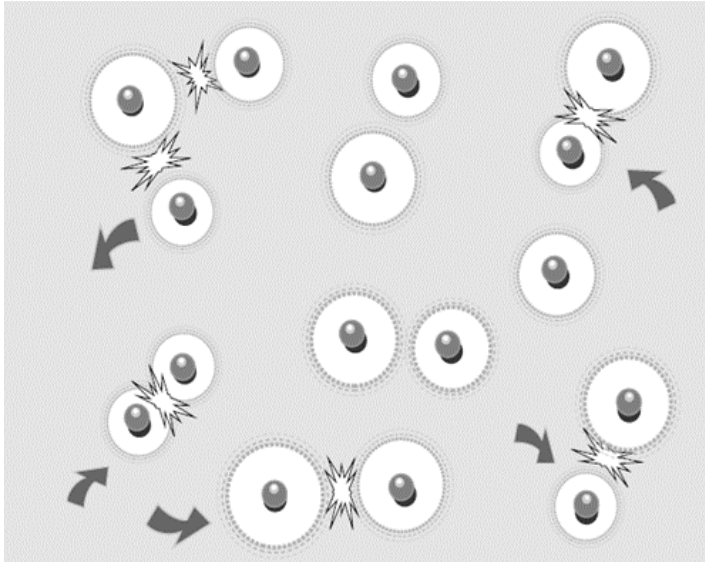

(a)

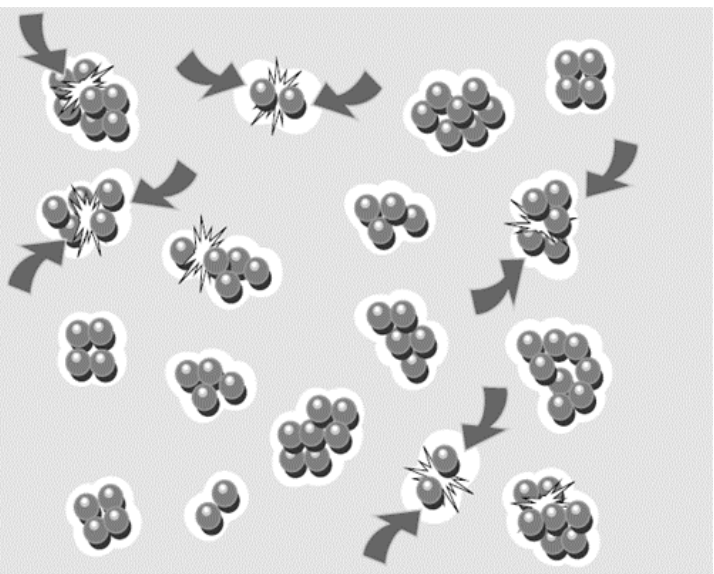

(b)

Figura 1 - Comportamento das partículas coloidais. (a) Partículas eletricamente carregadas se repelem. (b) Partículas eletricamente neutras colidem e agregam-se.

Fonte: Zeta-Meter, Inc., 1993 (11).

A desestabilização da dispersão pode ocorrer a partir de um mecanismo ou pela combinação de diferentes mecanismos, sendo eles: compressão da dupla camada elétrica; adsorção; neutralização de carga; adsorção; ponte interpartícula; e varredura (excesso de adição de coagulante).

\subsection{4. \\ Floculação}

"A floculação é o processo pelo qual as partículas desestabilizadas, ou formadas como resultado da desestabilização, são induzidas a se unirem, entrarem em contato e, assim, formarem maiores aglomerados." (10)

Logo após a coagulação, em um processo de agitação lenta, induz-se o fenômeno da floculação para que em seguida possam ser aplicados os processos de separação, como sedimentação, flotação e filtração. Nesta etapa é promovido o crescimento das partículas coaguladas ou desestabilizadas, através da colisão 
contínua entre os materiais particulados eletricamente desestabilizados (microflocos), que se unem formando flocos cada vez maiores (15).

A qualidade do floco formado é dependente do gradiente de velocidade da agitação aplicado. Busca-se a velocidade adequada para a promoção do crescimento apropriado dos flocos, com boa densidade e ramificações que possibilitem a agregação a outros flocos, resultando em estruturas maiores e mais densas (15).

A fim de conferir ao floco maior estabilidade e um crescimento acelerado, é possível recorrer à introdução de aditivos. Estes podem ser, polímeros inorgânicos ou polímeros orgânicos. Os flocos poderão ser removidos posteriormente pelos processos de decantação, flotação e filtração (17).

\subsection{5.}

\section{Coagulantes}

Os coagulantes mais comumente utilizados no processo de tratamento de águas são: carbonato de magnésio, cal hidratada e sais metálicos. Os coagulantes de sais metálicos podem ser divididos em duas categorias, baseadas no metal a qual o compõem, sendo estas os à base de ferro e à base de alumínio. A Tabela 2 exibe os tipos de coagulantes de sais metálicos mais comumente utilizados, de acordo com suas respectivas categorias.

Tabela 2 - Coagulantes mais comumente utilizados a base de ferro e de alumínio.

\begin{tabular}{|c|c|}
\hline \multirow{8}{*}{$\begin{array}{l}\text { Coagulantes à } \\
\text { base de } \\
\text { alumínio }\end{array}$} & Sulfato de alumínio \\
\hline & Cloreto de alumínio \\
\hline & Aluminato de sódio \\
\hline & Cloridrato de alumínio \\
\hline & Cloreto de polialumínio \\
\hline & Cloreto de sulfato de polialumínio \\
\hline & Cloreto de silicato de polialumínio \\
\hline & Cloreto de polialumínio com polímeros orgânicos \\
\hline \multirow{6}{*}{$\begin{array}{l}\text { Coagulantes à } \\
\text { base de ferro }\end{array}$} & Sulfato férrico \\
\hline & Sulfato ferroso \\
\hline & Cloreto férrico \\
\hline & Sulfato de cloreto férrico \\
\hline & Sulfato poliférrico \\
\hline & Sais férricos com polímeros \\
\hline
\end{tabular}

Fonte: Adaptado de ABIQUIM, 2016 (18) e Tzoupanos, 2008 (19) 
A eficácia na aplicação de coagulantes metálicos, decorre do fato de que quando adicionados ao sistema, hidrolisam-se rapidamente, sendo capazes de formar complexos mono e polinuclares multicarregados com alta capacidade de adsorção (10).

A Figura 2 exibe o resultado das sucessivas reações de hidrólise de coagulantes, com centros metálicos trivalentes de alumínio e ferro.
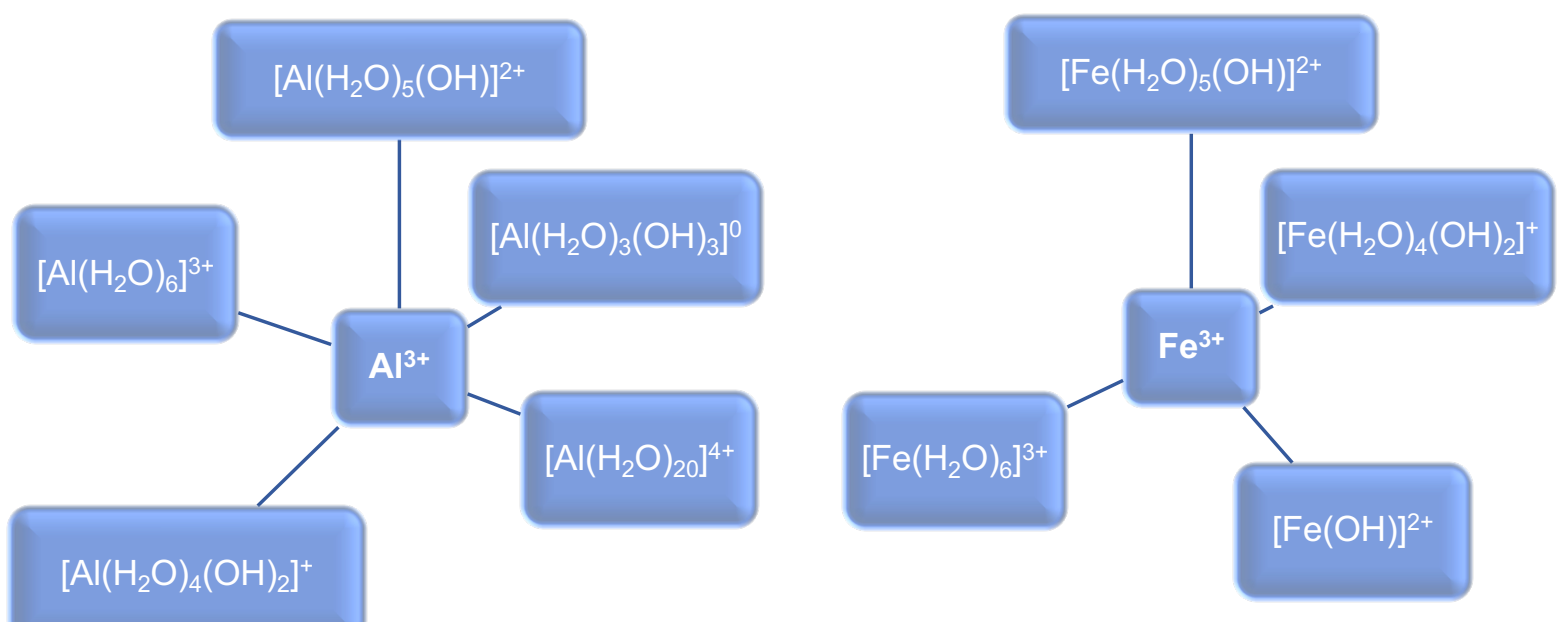

Figura 2 - Principais espécies hidrolisadas de coagulantes a base de alumínio e ferro com centros metálicos trivalentes.

Fonte: Adaptado de Lima e Abreu, 2018 (16).

Coagulantes a base de íons trivalentes, de carga oposta ao coloide, apresentam maior eficiência no processo de coagulação, que os coagulantes à base de íons bivalentes, como pode ser visto na Tabela 3. Esta relação entre a eficiência do poder coagulante e a carga iônica foi estabelecida como a regra de Schulze-Hardy: "A coagulação de um coloide é afetada pelo íon do eletrólito adicionado que contém a carga de sinal oposto ao da partícula coloidal, e o efeito aumenta significativamente com o número de cargas que este possui" (14). 
Tabela 3 - Poder relativo de coagulação de diferentes eletrólitos.

\begin{tabular}{c|c|c} 
& \multicolumn{2}{|c}{ Poder relativo de coagulação* } \\
\cline { 2 - 3 } Eletrólito & Coloides Positivos & Coloides Negativos \\
\hline $\mathrm{NaCl}$ & 1 & 1 \\
$\mathrm{Na} \mathrm{SO}_{4}$ & 30 & 1 \\
\hline $\mathrm{Na}_{3} \mathrm{PO}_{4}$ & 1000 & 1 \\
$\mathrm{AlCl}_{3}$ & 1 & 1000 \\
\hline $\mathrm{Al}_{2}\left(\mathrm{SO}_{4}\right)_{3}$ & 30 & $>1000$ \\
$\mathrm{FeCl}_{3}$ & 1 & 1000 \\
\hline $\mathrm{Fe}_{2}\left(\mathrm{SO}_{4}\right)_{3}$ & 30 & $>1000$ \\
* Valores aproximados e para soluções de concentrações iônicas equivalentes.
\end{tabular}

* Valores aproximados e para soluções de concentrações iônicas equivalentes.

Fonte: Adaptado de Sawyer e McCarty, 1994 (14).

Sais metálicos de Al (III) e Fe (III) são capazes de neutralizar as partículas coloidais por diferentes mecanismos. Ao serem adicionados a água ionizam-se formando íons metálicos livre $\left(\mathrm{Al}^{3+}, \mathrm{Fe}^{3+}\right)$. Uma pequena parte destes íons metálicos livres aderem a partícula coloidal neutralizando-a. A maioria destes íons hidrolisam-se, formando diferentes complexos de hidróxidos, capazes de adsorver na superfície do coloide, neutralizando-o ou comprimindo a sua camada dupla, e assim desestabilizando a suspensão. Em casos de excesso de agente coagulante, ocorre a rápida formação de flocos de hidróxidos metálicos que ao precipitarem capturam as partículas coloidais presentes no meio (14). Um exemplo de atuação destes mecanismos está representado pela Figura 3.

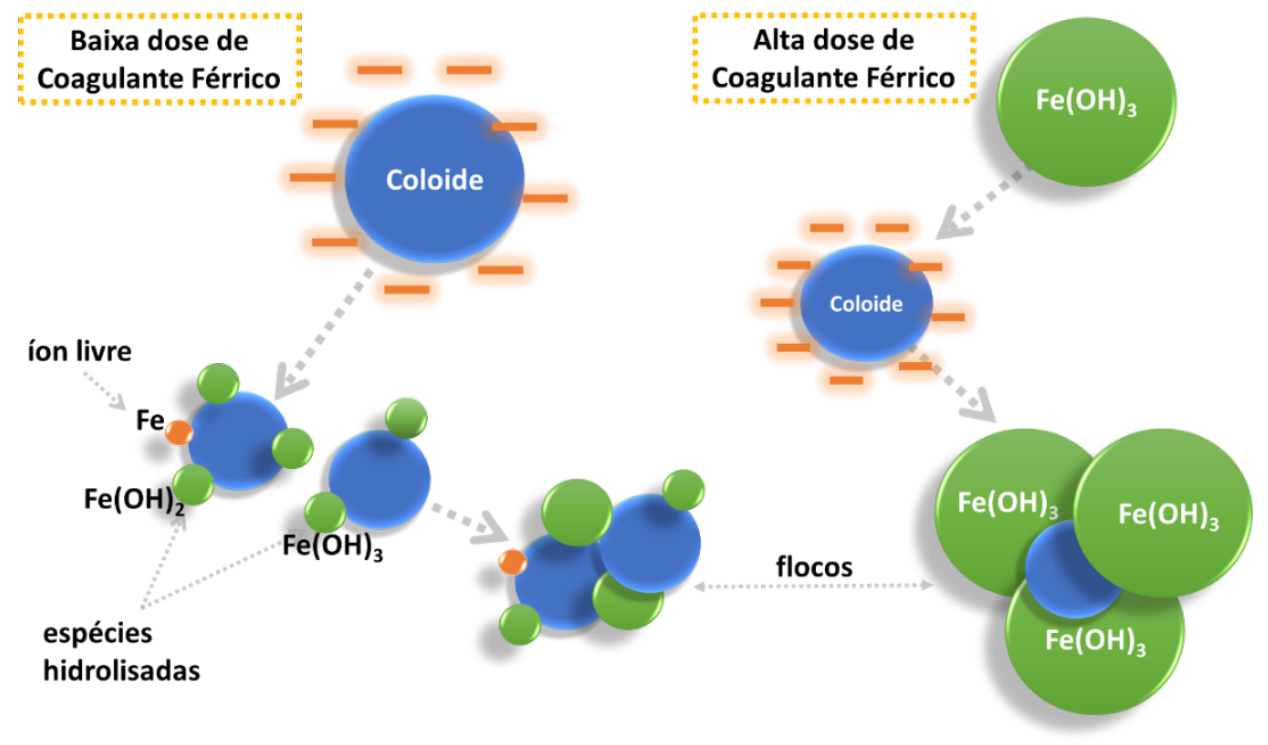

Figura 3 - Mecanismos de coagulação com coagulante férrico.

Fonte: Adaptação de Richter, 2009 (13) 
O sulfato de alumínio é um dos coagulantes mais comumente utilizados no tratamento de água para abastecimento público e efluentes industriais, devido ao seu baixo custo, disponibilidade no mercado e eficiência. Porém, devido à potencialidade tóxica do alumínio, há um aumento da substituição dos coagulantes a base de sais de alumínio pelos a base de sais de ferro (15).

O coagulante sulfato férrico comparado aos coagulantes à base de alumínio possui uma maior aplicabilidade devido à sua atuação em uma maior faixa de $\mathrm{pH}$, permitindo a sua utilização nos mais variados processos, como na descoloração de águas com baixo $\mathrm{pH}$, na remoção de manganês em altos pH e na clarificação de águas de baixa dureza temporária (14). Comparado ao sulfato de alumínio, o sulfato férrico gera um processo de sedimentação mais rápido, devido a uma maior densidade dos flocos formados, além de apresentar eficiência na remoção de algas e fósforo (11) (20).

O sulfato férrico e cloreto férrico podem ser utilizados para o tratamento de esgotos domésticos, de água potável para abastecimento público, de efluentes industriais e para condicionamento de lodos em estações de tratamento de efluentes. Ambos apresentam eficiência coagulante equivalente, porém, o sulfato férrico possui como diferencial menor custo, menor acidez e menor poder corrosivo. O alto poder corrosivo do cloreto férrico pode levar ao comprometimento de partes metálicas presentes nos sistemas de tratamento de efluentes (11).

Os coagulantes inorgânicos pré-hidrolisados, com base em alumínio e ferro, independem das condições do processo para resultar nas espécies hidrolisadas corretas, durante o tratamento. Tem-se como principais vantagens na utilização coagulantes inorgânicos pré-polimerizados: a capacidade destes em atuar de forma eficiente em largos intervalos de $\mathrm{pH}$ e temperaturas; a necessidade de doses menores, comparadas aos outros coagulantes, para cumprir o tratamento do efluente; e baixa produção de resíduos químicos (19).

Vale destacar que a seleção do coagulante no processo de tratamento de águas depende de diversos fatores, sendo eles, o tipo do sólido suspenso a ser removido, das condições da água bruta (ex. $\mathrm{pH}$, temperatura e turbidez), o efeito sobre o desempenho do processo de tratamento a jusante, das condições finais exigidas para a água, o custo atrelado à substância química e a da dose necessária para o tratamento e o custo e o método do manuseio e descarte do lodo formado. Por fim, é necessária uma avaliação da aplicabilidade do coagulante (ou coagulantes) pelo método de Jar-Test e a avaliação em escala da planta (17) (21). 


\subsection{6. Floculantes}

Os floculantes são adicionados ao sistema de tratamento quando os flóculos apresentam velocidades de sedimentação muito baixas, podendo também ser adicionados para otimizar a remoção dos sólidos (22). Geralmente, tais agentes floculantes são compostos poliméricos que agem auxiliando a sedimentação, isto é, aumentam a densidade dos flóculos e aumentam a resistência dos mesmos.

Os polímeros floculantes são geralmente macromoléculas orgânicas de cadeias longas compostas por pequenos grupos de monômeros (22). Estes polímeros podem ser catiônicos, aniônicos, não iônicos ou anfóteros. A classificação destes decorre da natureza química dos mesmos, podendo ser naturais ou sintéticos (11).

\section{2.}

\section{Sulfato férrico}

O sulfato férrico é um sal inorgânico utilizado com diversas finalidades. Algumas de suas aplicações estão: na produção de remédios; na produção de pigmentos para tecidos; desinfetante; no condicionamento do espessamento e desidratação de lodo; catalisador de polimerização; na decapagem de metais; controle de pragas em plantações; em produtos de ferro quelado; e no tratamento de águas residuárias e potáveis (23) (24).

No tratamento de águas residuais e potáveis o reagente sulfato férrico atua como um coagulante/floculante, devido ao alto peso molecular do ferro. Esta característica propicia a formação de flocos de alta densidade e estabilidade, induzindo floculações rápidas, com baixo tempo de decantação e alta eficiência no processo que se segue de filtração.

Uma das suas principais vantagens, comparado aos demais coagulantes é a sua aplicabilidade em um amplo intervalo de $\mathrm{pH}$ (4,5 a 12), dispensando a necessidade do ajuste deste parâmetro no efluente a ser tratado. Esta característica é atribuída devido à baixa solubilidade dos hidróxidos férricos formados, quando este coagulante é adicionado em águas (20).

Este coagulante de sal férrico é muito utilizado na descoloração de águas, na remoção de fosfato, metais e da turbidez e também para o controle de odor através da redução da liberação de sulfato de hidrogênio. 
A seguir, explicita-se as principais vantagens da utilização do sulfato férrico como coagulante-floculante de acordo com o tipo de efluente a ser tratado (25):

\section{Tratamento de efluentes urbanos:}

- Aplicação no tratamento primário para diminuição da carga orgânica, que segue para o tratamento biológico.

- Remoção de fosfatos, até $90 \%$.

\section{Tratamento de efluentes industriais:}

- Remoção de matéria orgânica e inorgânica, influenciando na redução da D.Q.O. e de D.B.O. do efluente.

- Remoção de fosfatos.

- Remoção de gorduras.

\section{Tratamento de água potável e industrial:}

- Alta eficiência na remoção de alumínio, ferro e manganês.

- Redução da turbidez e da cor.

Quando adicionado em água, o sulfato férrico forma hidróxido férrico altamente insolúvel. A reação do sulfato férrico em águas com alcalinidade natural é demostrada a seguir (26).

$$
\mathrm{Fe}_{2}\left(\mathrm{SO}_{4}\right)_{3}+3 \mathrm{Ca}\left(\mathrm{HCO}_{3}\right)_{2} \rightarrow 2 \mathrm{Fe}(\mathrm{OH})_{3 \text { sólido }}+3 \mathrm{CaSO}_{4}+6 \mathrm{CO}_{2}
$$

Dependendo do $\mathrm{pH}$ do meio, diferentes espécies de hidrolisadas do ferro (III) podem estar presentes em solução. As possíveis reações de hidrólise do ferro (III) em temperatura de $25^{\circ} \mathrm{C}$, são exibidas a seguir (20):

$$
\begin{aligned}
& \mathrm{Fe}(\mathrm{OH})_{3} \Leftrightarrow \mathrm{Fe}^{3+}+3 \mathrm{OH}^{-} \\
& \mathrm{Fe}^{3+}+\mathrm{H}_{2} \mathrm{O} \Leftrightarrow \mathrm{Fe}(\mathrm{OH})^{2+}+\mathrm{H}^{+} \\
& \mathrm{Fe}^{3+}+2 \mathrm{H}_{2} \mathrm{O} \Leftrightarrow \mathrm{Fe}(\mathrm{OH})^{2+}+2 \mathrm{H}^{+} \\
& 2 \mathrm{Fe}^{3+}+2 \mathrm{H}_{2} \mathrm{O} \Leftrightarrow \mathrm{Fe}(\mathrm{OH})^{4+}+2 \mathrm{H}^{+} \\
& \mathrm{Fe}^{3+}+4 \mathrm{H}_{2} \mathrm{O} \Leftrightarrow \mathrm{Fe}(\mathrm{OH})_{2}^{-}+4 \mathrm{H}^{+} \\
& \mathrm{Fe}^{3+}+3 \mathrm{H}_{2} \mathrm{O} \Leftrightarrow \mathrm{Fe}(\mathrm{OH})_{3}^{0}+3 \mathrm{H}^{+}
\end{aligned}
$$




\subsection{1.}

\section{Características físicas e requisitos físicos e químicos para a utilização do sulfato férrico para tratamento de águas e efluentes}

Este coagulante inorgânico é disponibilizado comercialmente nas formas: líquida, sendo uma solução caracterizada pela coloração marrom avermelhada, ou em forma granular, de coloração acastanhada. Como no presente trabalho é proposto a produção de uma solução de sulfato férrico, abaixo apresentam-se os requisitos mínimos que esta solução coagulante deve atender, definidos pela American Water Works Association (27).

\subsection{2.}

\section{Requisitos físicos}

A solução de sulfato férrico não deve apresentar materiais estranhos e deve ser transportado e entregue a uma tal concentração e temperatura que não ocorra o congelamento.

É necessário que a solução do coagulante esteja em condições adequadas para a sua alimentação no processo, através de bombas dosadoras e outros dispositivos resistentes à corrosão.

\subsection{3.}

\section{Requisitos Químicos}

- Ferro férrico. A concentração de ferro férrico solúvel em água $\left(\mathrm{Fe}^{3+}\right)$ deve ser igual ou maior que $9,0 \%$, salvo exceções em situações que haja acordo entre o fornecedor e o comprador.

- Ferro ferroso. O ferro ferroso solúvel em água $\left(\mathrm{Fe}^{2+}\right)$ não deve exceder $1,5 \%$, com base em $9,0 \%$ de ferro férrico.

- Matéria insolúvel em água. Limite de $0,1 \%$ do sulfato férrico presente em solução.

- Ácido livre. A estabilidade do produto deve ser assegurada pela presença de um ácido, como $\mathrm{H}_{2} \mathrm{SO}_{4}$, em quantidade suficiente afim de garantir que o pH da solução seja igual ou menor que 2 .

- Cloretos. Não é permitido concentrações superiores a 10 ppm de cloreto por cada $1 \%$ de teor de ferro férrico a $38^{\circ} \mathrm{C}$. 


\subsection{4.}

Impurezas

Impurezas gerais. Não é permitida a presença de substâncias em quantidades capazes de produzir efeitos nocivos à saúde daqueles que consomem água adequadamente tratada com sulfato férrico.

\subsection{5.}

\section{Métodos de produção de Sulfato Férrico}

- Produção em escala industrial

Os métodos de produção em escala industrial mais conhecidos deste coagulante envolvem a adição de ácido sulfúrico, podendo ou não haver uma etapa adicional de oxidação. Os agentes oxidantes utilizados normalmente variam entre o oxigênio, cloro, ácido nítrico e peróxido de hidrogênio. Estas operações ocorrem em condições especiais, geralmente em altas temperaturas e em sistemas pressurizados (28). No decorrer dos anos, foram desenvolvidos e patenteados diversos métodos para a produção de sulfato férrico, alguns destes métodos, já em domínio público, estão descritos neste tópico.

Em 1940, a patente U.S. 2.196.584 descreve um método de produção de sulfato férrico a partir da reação de sulfato ferroso com ácido sulfúrico em excesso e oxidação com ácido nítrico em temperaturas acima de $60^{\circ} \mathrm{C}$. A patente U.S. número 2.52.332, de 1941, descreve um processo no qual óxidos férricos insolúveis, provenientes de gases de fornos, reagem com ácido sulfúrico em temperaturas de aproximadamente $154^{\circ} \mathrm{C}$. A utilização do ácido nítrico também foi apresentada na em 1997 pela Patente U.S. 5.624.650, em um processo de oxidação de sulfato férrico de amônio, jarosita de amônia ou um outro complexo de ferro similar, operando em temperaturas próximas de $60^{\circ} \mathrm{C}$. Em 2002, a patente US 6.375.919 descreve um processo, utilizando minérios de ferro contendo $30 \%$ de $\mathrm{FeOOH}$, dividido em duas etapas, onde primeiramente calcina-se os minérios, em temperaturas entre $200-600{ }^{\circ} \mathrm{C}$, e em seguida os dissolve em ácido sulfúrico. É apresentado pela Patente U.S. 7.067.100, em 2006, um método de produção onde o processo ocorre em uma só etapa, operando em uma faixa de temperatura entre $130^{\circ} \mathrm{C}$ e $150^{\circ} \mathrm{C}$ e pressão entre $2 \mathrm{~atm}$ e $8 \mathrm{~atm}$, produzindo sulfato férrico a partir de óxido férrico finamente dividido em um vaso reacional fechado contendo ácido sulfúrico e água. A Patente U.S. 8.658.124, do ano de 2014, exibe um processo similar, porém utilizando hematita ou magnetita e tem como opcional a introdução de oxigênio no sistema reacional (28). 
A patente US 4.707 .349 de 1987 , descreve um processo de produção de sulfato férrico em duas etapas de oxidação, onde em uma delas envolve utilização do peróxido de hidrogênio. Inicialmente ocorre a dissolução de ferro ou óxidos de ferro em ácido sulfúrico para a formação de sulfato ferroso. Em um vaso pressurizado, a primeira etapa de oxidação ocorre pela adição de oxigênio ao meio reacional, como ar comprimido ou oxigênio líquido, conjuntamente com a adição de mais ácido sulfúrico. Preferivelmente, nesta etapa é necessário manter a condição de pressão igual a 6,805 atm. e temperatura entre $82,22{ }^{\circ} \mathrm{C}$ e $104,44^{\circ} \mathrm{C}$, com tempo reacional entre 8 e 12 horas utilizando um catalisador. A segunda etapa de oxidação ocorre via adição lenta de um oxidante à base de oxigênio nãomolecular, como o peróxido de hidrogênio, o persulfato de amônio, o ozônio e o dióxido de cloro. Esta etapa deve ocorrer em pressão atmosférica após o resfriamento da solução, a qual deverá atingir uma temperatura de aproximadamente $54{ }^{\circ} \mathrm{C}$, e deve perdurar até que haja a conversão completa do sulfato ferroso em solução em sulfato férrico, necessitando de aproximadamente 3 horas. Em ambas as fases de oxidação, fica a critério do operador a adição de um catalisador, como o sulfato de cobre e sulfato amônio e cobre (29). Vale ressaltar que a segunda etapa de adição ocorre de forma lenta devido ao risco de explosão gerado pela alta temperatura do meio reacional em conjunto com a reação altamente exotérmica de oxidação pelo peróxido de hidrogênio.

Como pode ser observado, as condições do processo acima descrito utilizando peróxido de hidrogênio dividem-se em duas etapas extremamente dispendiosas. A primeira etapa necessita de um vaso de pressão e altas temperaturas durante todo o processo de oxidação utilizando oxigênio, perdurando por mais de 8 horas, desta forma, requerendo uma grande quantidade de energia durante um longo período de tempo. A segunda etapa requer inicialmente um resfriamento da solução inicial, o que pode ser traduzido em custo de tempo e/ou energia, e em seguida a adição do peróxido de hidrogênio requer um elevado tempo operacional até a completa conversão, devido às condições operacionais de temperatura impostas, acarretando em altos custos operacionais. Portanto, o método de produção apresentado pela patente US 4.707.349 acarreta em um processo altamente dispendioso, inviabilizando a produção do coagulante utilizando o peróxido de hidrogênio, frente aos demais métodos de produção de sulfato férrico que empregam outros oxidantes, incluindo também o clorato de sódio, comumente empregado no Brasil. 
- Métodos alternativos

Devido ao potencial poluidor e grande quantidade de metais com alto valor agregado contidos nos rejeitos produzidos pelo beneficiamento do carvão mineral, é possível encontrar estudos sobre o desenvolvimento de métodos alternativos voltados para a recuperação de tais metais. Dentre alguns destes estudos, apresentam-se métodos para a produção do coagulante sulfato férrico, para aplicação no tratamento de águas.

Os métodos de produção do coagulante férrico produzido a partir dos rejeitos, provenientes do beneficiamento do carvão mineral, utilizam a pirita (FeS) e/ou a Drenagem Ácida de Mina (DAM) como matéria prima para a obtenção de ferro.

Vale ressaltar que devido a presença de outros metais dissolvidos presentes na DAM, a co-precipitação destes ocorre invariavelmente durante o processo de obtenção dos hidróxidos férricos, causando a contaminação do coagulante obtido como produto final. Portanto, durante o processo de obtenção de coagulantes utilizados em tratamentos de água a partir da DAM, se faz necessário a aplicação de outras técnicas que minimizem a precipitação dos metais contaminantes (30).

Rao et al. (1992) demonstrou a possibilidade de se obter o coagulante sulfato férrico a partir do lodo da DAM. Primeiramente, foi aplicado o processo de precipitação seletiva para a obtenção dos hidróxidos férricos. Em seguida, a obtenção do coagulante ocorreu pela solubilização dos hidróxidos férricos em ácido sulfúrico (30).

Menezes (2009) apresentou um estudo para a produção de sulfato férrico a partir da lixiviação de concentrado de pirita, em colunas de percolação com água, ar e bactérias acidófilas e, também, pela dissolução do lodo férrico, provindo da DAM, em ácido sulfúrico. O processo de lixiviação descrito ocorre em ciclos, onde cada ciclo perdura por no mínimo 5 semanas e no máximo 10 semanas. O processo de dissolução do lodo férrico apresentado ocorre a $90{ }^{\circ} \mathrm{C}$ e perdura por 1 hora (17).

Silva (2010) buscou um método para a produção do coagulante sulfato férrico e pigmentos, aplicados na produção de tintas, através de um estudo voltado para a recuperação dos metais com alto valor agregado contidos na DAM. Através da precipitação seletiva da DAM, foi possível produzir os coagulantes sulfatos férricos e sulfato férrico-aluminoso. Os metais obtidos em forma de hidróxidos, foram dissolvidos em quantidades estequiométricas de ácido sulfúrico e em 
seguida aquecidos a uma temperatura de 80 a $90^{\circ} \mathrm{C}$. A solução final do coagulante produzido foi concentrada pela evaporação em banho maria a $30^{\circ} \mathrm{C}(31)$.

Villeti (2017) obteve o coagulante sulfato férrico a partir da lixiviação de um concentrado de pirita, oriundo de rejeitos de carvão via cristalização e solubilização de sulfato ferroso. A oxidação dos cristais de sulfato ferroso ocorreu com peróxido de hidrogênio em meio ácido. Para a produção de 1 litro de coagulante férrico foram utilizados $166,6 \mathrm{~mL}$ de peróxido de hidrogênio $50 \%$, 28 $\mathrm{mL}$ de ácido sulfúrico $95 \%$ e $805,4 \mathrm{~mL}$ de água (32). O estudo não apresentou as condições na qual o peróxido de hidrogênio foi adicionado ao meio. A análise química apontou a presença de alumínio na composição final do coagulante e a análise econômica não apontou ganhos econômicos na produção do coagulante em comparação com o coagulante férrico já comercializado.

\subsection{6.}

\section{Princípios necessários na produção de sulfato férrico}

Como o presente trabalho aborda um estudo voltado para a produção de sulfato férrico a partir do sulfato ferroso, tendo a sua utilização direcionada para o tratamento de águas, vale destacar premissas pertinentes à produção do mesmo.

Durante a produção do sulfato férrico, a partir da oxidação do sulfato ferroso, é necessário garantir que haja uma alta taxa de conversão deste composto de ferro II, para atingir as especificações do produto. Devido às suas diferentes propriedades de solubilização, onde o sulfato férrico apresenta maior solubilidade que o sulfato ferroso, podem ocorrer situações de cristalização do sal de ferro II dentro de equipamentos do sistema de tratamento, quando este está presente nos produtos para tratamento de águas a base de ferro III. Outro fator é que diferentemente dos hidróxidos férricos, formados pela adição de sulfato férrico em água, os hidróxidos ferrosos, formados pela adição de sulfato ferroso em águas, apresentam uma maior solubilidade, impossibilitando a sua separação do efluente no processo de floculação em valores de $\mathrm{pH}$ próximos da neutralidade. Portanto, a presença deste componente pode representar uma possibilidade de contaminação da água ou efluente durante o processo de tratamento.

Uma outra importante característica a ser monitorada durante a produção do coagulante sulfato férrico é o excesso de acidez do produto final. A oxidação do sulfato ferroso resulta em óxido férrico e sulfato férrico, e quando este processo ocorre na presença de ácido sulfúrico, o produto principal resultante da oxidação é o sulfato férrico. Isto ocorre pois, em meio ácido ocorre a dissociação dos íons 
de ferro dos íons de sulfato, favorecendo desta forma a oxidação do ferro. Porém, caso haja um excesso de ácido sulfúrico livre presente no produto utilizado para o tratamento de águas, tornar-se-á necessário a utilização de aditivos para a correção do $\mathrm{pH}$ da água ou efluente. Além do aspecto financeiro e operacional, devido à necessidade do emprego dos compostos alcalinos para a correção do $\mathrm{pH}$ durante o processo, o excesso de acidez pode afetar o processo de formação dos flocos e também ser prejudicial aos equipamentos que constituem o sistema de tratamento (33) (29). Portanto, o presente trabalho buscou estudar as melhores condições para atingir conversões satisfatórias do sulfato ferroso em férrico, tendo como objetivo a produção do coagulante sulfato férrico dentro dos requisitos comerciais em um processo com a mínima adição de ácido sulfúrico.

\section{3. \\ Peróxido de Hidrogênio}

Devido às suas importantes propriedades e complexidades, desde a sua primeira síntese, o peróxido de hidrogênio continua sendo objeto de estudo nos mais variados campos, o que resultou na possibilidade de aplicação deste reagente nos mais diversos propósitos. Atualmente este reagente representa uma importante alternativa, em virtude da sua eficiência e por ser considerado um dos reagentes químicos mais limpos.

\subsection{1. \\ Contexto histórico e produção atual}

A descoberta do peróxido de hidrogênio foi apresentada à Academia de Ciências de Paris, em julho de 1818, pelo químico francês Louis Jacques Thenard. Ao investigar os óxidos alcalino-terrosos, o pesquisador francês constatou que a reação do peróxido de bário com ácido nítrico frio resultava na formação do peróxido de hidrogênio, primeiramente nomeado como "água oxigenada" por se acreditar que se tratava de uma solução a qual continha oxigênio dissolvido (33). Aproximadamente em 1880, iniciou-se a produção do peróxido de hidrogênio em larga escala, tendo como principal finalidade industrial a aplicação no branqueamento de chapéus de palha. Contudo, o método de produção utilizado acarretava em um produto final com limites operacionais para sua aplicação industrial, fazendo com que fossem desenvolvidas diversas outras formas mais eficientes do método de produção deste reagente, ao longo dos anos seguintes, visando um produto com maior estabilidade e concentração (34). 


\subsection{2.}

\section{Aplicação do Peróxido de Hidrogênio}

Ao longo dos anos, este reagente teve a sua aplicação expandida para as mais diversas áreas, de forma isolada e também de forma combinada, sendo mais comumente utilizado como agente oxidante.

Devido à sua versatilidade como oxidante, isto é, por apresentar seletividade sob determinadas condições experimentas, como a temperatura do meio reacional, a sua concentração, tempo de reação, adição ou não de catalisadores, etc., o peróxido de hidrogênio tem o seu uso superior ao do cloro, dióxido de cloro e permanganato de potássio (35). O emprego deste reagente, preferivelmente a outros, em processos, também se justifica pela alta eficiência, redução de custos atrelados e por não representar um oxidante contaminante, já que resulta em água e oxigênio quando decomposto e, portanto, ambientalmente atraente.

Sua ação oxidante é frequentemente empregada nos processos de branqueamento de polpa de celulose e de fibras têxteis, devido ao seu alto desempenho e por ser essencial no chamado branqueamento ECF (Elemental Chlorine Free) e TCF (Total Chlorine Free), na fabricação de compostos químicos e preparação de outros oxidantes, na eliminação de poluentes e substâncias tóxicas e no tratamento de superfície de metais, para decapagem de cobre e substituindo misturas fluoretadas no tratamento de aços inoxidáveis, zircônio, titânio, etc. Em virtude de suas propriedades desinfetante e antissépticas, este reagente também é amplamente aplicado nas indústrias alimentícias e farmacêuticas (36).

A Tabela 4 apresenta diversas áreas de aplicação do peróxido de hidrogênio, de acordo com a sua forma de aplicação. 
Tabela 4 - Campos de aplicação do peróxido de hidrogênio

\section{Forma Isolada}

Controle de odores

Controle da corrosão

Oxidação de componentes inorgânicos

Oxidação de poluentes orgânicos

Oxidação de componentes orgânicos
Oxidação de sulfeto de hidrogênio

Eliminação de cloro residual, tiossulfato, sulfetos e sulfitos

Cianetos, $\mathrm{NO}_{\mathrm{x}} / \mathrm{SO}_{\mathrm{x}}$, nitritos, hidrazinas, etc.

Redução da demanda química e bioquímica de oxigênio

Hidrólise de formaldeído, carboidratos, componentes nitrogenados etc., destruição de fenóis, pesticidas, solventes, plastificantes, entre outros;

Desinfecção, inibição de crescimento de bactérias etc.

\section{Forma Combinada}

\begin{tabular}{l|l}
\hline $\begin{array}{l}\text { Processo de floculação e/ou } \\
\text { precipitação }\end{array}$ & $\begin{array}{l}\text { Oxidação de complexos metálicos e } \\
\text { incremento no desempenho } \\
\text { de floculante inorgânicos; }\end{array}$ \\
Tratamento de bioprocessos & $\begin{array}{l}\text { Desinfecção, fonte de oxigênio dissolvido } \\
\text { etc. }\end{array}$ \\
\hline \hline
\end{tabular}

Fonte: Yazici e Deveci, 2010 (37)

A aplicabilidade de processos envolvendo a utilização do peróxido de hidrogênio, tanto como oxidante direto quanto percursos de espécies oxidativas, é limitada por fatores que induzem a sua rota de auto decomposição. A decomposição resultante em água e oxigênio, acarreta no aumento do consumo do reagente, o que pode significar a inviabilização da sua aplicação por fatores econômicos. Sendo assim, torna-se necessário uma melhor compreensão sobre 
como os fatores envolvidos em um meio reacional afetam a eficiência dos peróxidos de hidrogênio em um processo.

\subsection{3.}

\section{Decomposição do Peróxido de Hidrogênio}

O estado de oxidação de -1 dos átomos de oxigênio presentes no peróxido de hidrogênio representa uma particularidade a esta substância, uma vez que grande parte deste átomo presente em outras substâncias apresenta estado de oxidação de 0 ou 2. Esta característica, além de proporcionar uma estrutura molecular singular, confere, ao reagente, a capacidade de agir como um agente redutor ou oxidante, de acordo com o pH da solução em que se encontra, e também decompor-se em uma reação de dismutação, exibida pela Figura 4 (38).

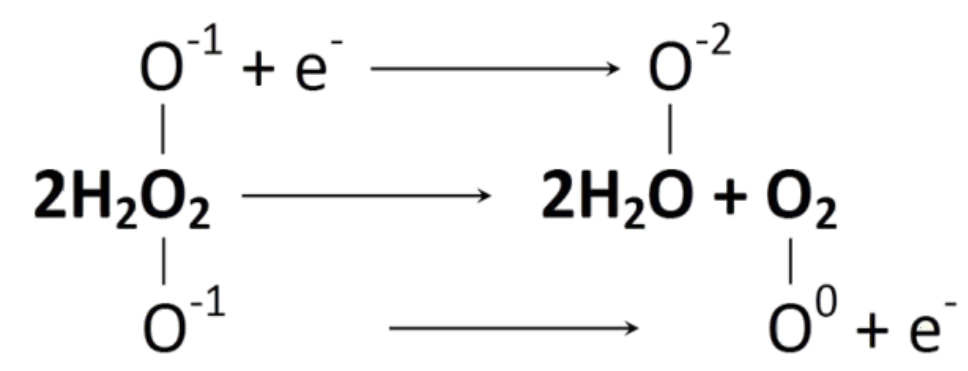

Figura 4 - Reação de dismutação do peróxido de hidrogênio.

Fonte: Pędziwiatr, et al., 2018 (26)

O peróxido de hidrogênio $\left(\mathrm{H}_{2} \mathrm{O}_{2}\right)$ é um composto inorgânico molecular, que possui alto poder oxidante e se apresenta na forma líquida de cor levemente azulada ou incolor quando diluído e levemente mais viscoso que a água. Ao sofrer uma catálise, o processo de decomposição do peróxido de hidrogênio pode levar à formação de radicais hidroxila $(\bullet \mathrm{OH})$, as quais possuem uma alta reatividade, inferior apenas à do flúor. Os compostos oxidantes mais fortes, em ordem decrescente de potenciais padrão (em V) estão apresentados na Tabela 5. 
Tabela 5 - Espécies Oxidantes e respectivos potencias de oxidação

Potencial de Oxidação

Espécie Oxidante

(V)

\begin{tabular}{l|c} 
Flúor & 3,0 \\
Radical Hidroxila & 2,8 \\
Ozônio & 2,1 \\
Peróxido de Hidrogênio & 1,77 \\
Permanganato de Potássio & 1,7 \\
Dióxido de cloro & 1,5 \\
Cloro & 1,4
\end{tabular}

Quando estocado em condições seguras, o peróxido de hidrogênio é um reagente relativamente estável, com decomposição de aproximadamente 1 \%/ano. Porém, quando perturbado por determinados fatores, este reagente oxidante pode entrar em um processo de auto decomposição altamente exotérmico, liberando aproximadamente $2884.5 \mathrm{~kJ} / \mathrm{kg} \mathrm{H} \mathrm{H}_{2} \mathrm{O}_{2}$, em conjunto com a liberação oxigênio em estado gasoso (38). O somatório de tais fatores pode gerar um ambiente favorável à promoção da combustão de diversos materiais orgânicos, como roupas, madeiras, etc. (33).

Soluções comerciais de peróxido de hidrogênio contém agentes estabilizantes, substâncias quelantes e/ou sequestrantes de metais, que minimizam a decomposição deste reagente quando em condições normais de armazenamento e manuseio. Tais agentes estabilizantes podem ser por exemplo o estanato coloidal, pirosfosfato de sódio, organosfosfonatos e silicato coloidal. Vale ressaltar que tais estabilizadores não afetam o desempenho do peróxido de hidrogênio em suas diversas aplicações.

O comportamento de decomposição do peróxido de hidrogênio em diferentes meios reacionais foi amplamente estudado ao longo dos anos. Porém, apesar dos extensivos estudos sobre tal fenômeno, por diversos pesquisadores, todos os mecanismos envolvidos no processo ainda não foram claramente elucidados (39). O desafio científico encontra-se na velocidade de formação dos intermediários nas reações.

Abaixo, apresentam-se os mecanismos mais aceitos e utilizados pela comunidade cientifica, para a decomposição de tal reagente. 


\subsubsection{1.}

\section{Fatores que afetam a decomposição do peróxido de hidrogênio}

$\mathrm{O}$ pH do meio reacional, a pressão, a exposição à luz solar, a concentração do peróxido de hidrogênio em solução, a presença de contaminantes (decomposição catalítica) e a temperatura (decomposição térmica), são fatores que influenciam na decomposição do peróxido de hidrogênio (38) (40) (41). Em um estudo feito por Yazici e Deveci (2010), foi demonstrado que a concentração de um metal contaminante e a variação na temperatura são os fatores que mais contribuem para o processo de decomposição do peróxido de hidrogênio.

Quando em ambiente diluído, a solução de peróxido de hidrogênio sofre menos com as mudanças de temperatura, pois a água promove um meio para dispersão de calor, reduzindo a taxa de auto decomposição do agente oxidante/redutor. Porém, em altas temperatura e ou na presença de contaminantes, estes podendo ser inorgânicos ou orgânicos, a taxa de decomposição do peróxido de hidrogênio é radicalmente elevada. O calor liberado pela decomposição é suficiente para gerar a vaporização da água, presente em solução, promovendo um processo de reação auto catalítica (42).

Devido às suas características reações de oxidação/redução e de auto decomposição altamente exotérmicas, a utilização do peróxido de hidrogênio em processos necessita de especial atenção à segurança, a fim de evitar dificuldades em sua utilização.

\subsubsection{2.}

\section{Auto decomposição}

A auto decomposição do peróxido de hidrogênio resulta na geração de água e oxigênio. Os principais fatores que propiciam este fenômeno são: a temperatura, a concentração de peróxido de hidrogênio e a presença de contaminantes, como metais (37).

A reação geral deste processo é:

$$
2 \mathrm{H}_{2} \mathrm{O}_{2} \rightarrow 2 \mathrm{H}_{2} \mathrm{O}+\mathrm{O}_{2}
$$

A reação de decomposição do peróxido de hidrogênio é tida como irreversível, visto que ocorre a formação de um produto gasoso e este deixa o meio reacional aquoso (42), como demonstrado pela equação 8. 


\subsubsection{3.}

\section{Decomposição Catalisada por Metais}

$\mathrm{Na}$ presença de metais, o peróxido de hidrogênio se decompõe mais rapidamente, havendo a formação do radical hidroxila $(\bullet \mathrm{OH})$, do íon hidróxido $(\mathrm{OH}-)$ e também do radical hidroperoxila $(\bullet \mathrm{OOH})(43)$.

A decomposição catalítica na presença de ferro e com ausência de outros substratos promove uma gama de reações, demonstradas a seguir.

Vale salientar que as espécies aquosas de ferro quando em solução apresentam-se como aquo-complexos, porém visando simplificar a apresentação das reações, omitiu-se os as águas de hidratação.

As constantes cinéticas apresentadas foram determinadas a $25^{\circ} \mathrm{C}$ e sem a presença de contaminantes orgânicos, não foram encontrados dados explicitando a mudança nas velocidades das reações em temperaturas inferiores a esta (44).

$$
\begin{array}{rr}
\mathrm{H}_{2} \mathrm{O}_{2}+\mathrm{Fe}^{2+} \rightarrow \mathrm{Fe}^{3+}+\mathrm{OH}^{-}+\bullet \mathrm{OH} & \mathrm{k}_{13}=76 \mathrm{M}^{-1} \mathrm{~s}^{-1} \\
\bullet \mathrm{OH}+\mathrm{Fe}^{2+} \rightarrow \mathrm{Fe}^{3+}+\mathrm{OH}^{-} & \mathrm{k}_{14}=3,2 \times 10^{8} \mathrm{M}^{-1} \mathrm{~s}^{-1}
\end{array}
$$

Os íons férricos formados podem induzir a decomposição catalítica do $\mathrm{H}_{2} \mathrm{O}_{2}$, em $\mathrm{H}_{2} \mathrm{O}$ e $\mathrm{O}_{2}$, sendo um processo dependente do $\mathrm{pH}$ do meio, como demonstrado pelas equações a seguir.

$$
\begin{array}{lrl}
\mathrm{H}_{2} \mathrm{O}_{2}+\mathrm{Fe}^{3+} \Leftrightarrow \mathrm{Fe}^{2+}+\mathrm{H}^{+}+\bullet \mathrm{OOH} & \mathrm{k}_{15}=0,001-0,01 \mathrm{M}^{-1} \mathrm{~s}^{-1} \\
\bullet \mathrm{OOH}+\mathrm{Fe}^{2+} \rightarrow \mathrm{Fe}^{3+}+\mathrm{HO}_{2}^{-} & \mathrm{k}_{16}=1,3 \times 10^{6} \mathrm{M}^{-1} \mathrm{~s}^{-1} \\
\bullet \mathrm{OOH}+\mathrm{Fe}^{3+} \rightarrow \mathrm{Fe}^{2+}+\mathrm{H}^{+}+\mathrm{O}_{2} & \mathrm{k}_{17}=1,2 \times 10^{6} \mathrm{M}^{-1} \mathrm{~s}^{-1}
\end{array}
$$

As reações demonstradas pelas equações (11) e (13) são denominadas reações Fenton-like.

Em casos onde há um grande excesso de $\mathrm{H}_{2} \mathrm{O}_{2}$ e baixa concentração de $\mathrm{Fe}^{2+}$ em relação a concentração de $\mathrm{Fe}^{3+}$, o radical hidroxila $(\bullet \mathrm{OH})$ pode atuar no processo de decomposição do $\mathrm{H}_{2} \mathrm{O}_{2}$, como exibido pela equação 14 .

$$
\mathrm{H}_{2} \mathrm{O}_{2}+\bullet \mathrm{OH} \rightarrow \mathrm{H}_{2} \mathrm{O}+\bullet \mathrm{OOH} \quad \mathrm{k}_{18}=2,7 \times 10^{7} \mathrm{M}^{-1} \mathrm{~s}^{-1}
$$


Observa-se através das equações acima, que a formação de íons ferrosos é beneficiada pelas suas maiores constantes de velocidade de formação, comparadas as demais reações.

No Anexo 9.1, encontram-se todas as reações conhecidas que ocorrem quando há a presença de metais em solução com o peróxido de hidrogênio.

\subsubsection{4.}

\section{Decomposição na presença de Sulfato}

Como no presente trabalho o sulfato encontra-se presente no meio reacional, vale explicitar as reações que ocorrem com este ânion em solução.

Abaixo, são mostradas as reações que ocorrem entre o peróxido de hidrogênio e os íons de sulfato, e também a formação de complexos com os íons metálicos presentes na solução (45) (46).

Novamente, vale ressaltar que as constantes cinéticas apresentadas foram calculadas a $25^{\circ} \mathrm{C}$ e sem a presença de contaminantes orgânicos, não foram encontrados dados explicitando a mudança nas velocidades das reações em temperaturas inferiores a esta.

$$
\begin{array}{ll}
\mathrm{Fe}^{2+}+\mathrm{SO}_{4}^{2-} \Leftrightarrow \mathrm{FeSO}_{4} & \mathrm{k}_{19}=2,29 \times 10^{1} \mathrm{M}^{-1} \\
\mathrm{Fe}^{3+}+\mathrm{SO}_{4}^{2-} \Leftrightarrow \mathrm{FeSO} \mathrm{H}^{+} & \mathrm{k}_{20}=3,89 \times 10^{2} \mathrm{M}^{-1} \\
\mathrm{Fe}^{3+}+2 \mathrm{SO}_{4}^{2-} \Leftrightarrow \mathrm{Fe}\left(\mathrm{SO}_{4}\right)_{2}^{-} & \mathrm{k}_{21}=4,47 \times 10^{3} \mathrm{M}^{-2} \\
\mathrm{H}^{+}+\mathrm{SO}_{4}^{2-} \Leftrightarrow \mathrm{HSO}_{4}^{-} & \mathrm{k}_{22}=3,47 \times 10^{1} \\
\bullet \mathrm{OH}+\mathrm{H}_{2} \mathrm{SO}_{4} \rightarrow \mathrm{SO}_{4}^{\cdot-}+\mathrm{H}^{+}+\mathrm{H}_{2} \mathrm{O} & \mathrm{k}_{23}=1,4 \times 10^{7} \mathrm{M}^{-1} \mathrm{~s}^{-1} \\
\mathrm{HSO}_{4}^{-}+\bullet \mathrm{OH} \rightarrow \mathrm{SO}_{4}^{--}+\mathrm{H}_{2} \mathrm{O} & \mathrm{k}_{24}=3,5 \times 10^{5} \mathrm{M}^{-1} \mathrm{~s}^{-1} \\
\mathrm{SO}_{4}^{-}+\mathrm{HO}^{-} \rightarrow \mathrm{SO}_{4}^{2-}+\bullet \mathrm{OH} & \mathrm{k}_{25}=1,4 \times 10^{7} \mathrm{M}^{-1} \mathrm{~s}^{-1} \\
\mathrm{SO}_{4}^{-}+\mathrm{H}_{2} \mathrm{O}_{2} \rightarrow \mathrm{SO}_{4}^{2-}+\mathrm{H}^{+}+\bullet \mathrm{OOH} & \mathrm{k}_{26}=1,2 \times 10^{7} \mathrm{M}^{-1} \mathrm{~s}^{-1} \\
\mathrm{SO}_{4}^{-}+\bullet \mathrm{OOH} \rightarrow \mathrm{SO}_{4}^{2-}+\mathrm{H}^{+}+\mathrm{O}_{2} & \mathrm{k}_{27}=3,5 \times 10^{9} \mathrm{M}^{-1} \mathrm{~s}^{-1} \\
\mathrm{SO}_{4}^{-}+\mathrm{Fe}^{2+} \rightarrow \mathrm{SO}_{4}^{2-}+\mathrm{Fe}^{3+} & \mathrm{k}_{28}=3,0 \times 10^{8} \mathrm{M}^{-1} \mathrm{~s}^{-1} \\
\mathrm{SO}_{4}^{-}+\mathrm{H}_{2} \mathrm{O} \rightarrow \mathrm{H}^{+}+\mathrm{SO}_{4}^{2-}+\bullet \mathrm{OH} & \mathrm{k}_{29}=6,6 \times 10^{2} \mathrm{~s}^{-1} \\
\mathrm{Fe}_{2} \mathrm{SO}_{4}+\mathrm{H}_{2} \mathrm{O}_{2} \rightarrow \mathrm{Fe}^{3+}+\mathrm{SO}_{4}^{2-}+\mathrm{H}_{2} \mathrm{O}+\bullet \mathrm{OH}+\mathrm{OH}^{-} \\
& \mathrm{k}_{30}=78 \mathrm{M}^{-1} \mathrm{~s}^{-1}
\end{array}
$$

De acordo com Truong et.al. (2003), a formação do complexo $\mathrm{FeSO}_{4}$ demonstrouse benéfica para o processo de formação de íons férricos, visto que a reação de 
oxidação do complexo $\mathrm{FeSO}_{4}$ pelo $\mathrm{H}_{2} \mathrm{O}_{2}$, equação 26, apresenta uma taxa de reação superior à do $\mathrm{Fe}^{2+}$ pelo $\mathrm{H}_{2} \mathrm{O}_{2}$, equação 9. Outro ponto que vale ser comentado, é que a taxa geral de oxidação do $\mathrm{Fe}^{2+}$ pelo $\mathrm{H}_{2} \mathrm{O}_{2}$ é controlada pela taxa de formação do seu intermediário ativo, $\bullet O H$, não sendo afetada pela formação dos radicais $\mathrm{SO}_{4}^{-}$- através da reação com radical hidroxila (45).

\section{4.}

\section{Planejamento de Experimentos}

O planejamento fatorial estatístico consiste em um conjunto de técnicas sistemáticas fundamentadas em teoremas estatísticos, sendo uma poderosa estratégia para a otimização de processos. Nos últimos anos, esta importante ferramenta vem sendo largamente utilizada em conjunto com a simulação computacional. A união destes recursos, desempenham um papel crucial no desenvolvimento e otimização de produtos e processos, devido ao seu potencial na redução de custos e tempo, maximização da produtividade, rendimento e especificidade de produtos (47).

Dentre as vantagens já citadas, a execução de um Planejamento de Experimento tem por finalidade suprir informações sobre o relacionamento de diferentes fatores, ou seja, explicitar quais são os impactos de cada fator na reposta analisada e como eles se relacionam, em nível de interação entre fatores. Sendo assim, o Planejamento Fatorial de Experimentos é uma abordagem utilizada para se montar e organizar um experimento, definindo a priori quais são os fatores e os níveis de regulagens a fim de avaliar como esses fatores influenciam nas respostas do processo.

\subsection{1.}

\section{Princípios básicos de planejamento e otimização de Processos}

Previamente à definição do modelo de planejamento a ser utilizado é necessário ter o máximo de informações possíveis sobre o processo, a fim de que seja possível a identificação de todas as variáveis e as suas respectivas faixas de estudo, que devem estar inclusas na análise. O domínio sobre o processo evita um desperdício de tempo e recursos, alcançando de forma mais eficiente a resposta ao problema.

A definição da técnica de planejamento a ser aplicada está intimamente relacionada ao número de variáveis independentes ou fatores pertencentes ao processo a ser estudado, pois o aumento no número de variáveis independentes 
amplia o número de experimentos a serem realizados, podendo inviabilizar o estudo devido à elevação do custo de tempo e execução das análises. A necessidade da condução de um estudo que investigue simultaneamente o efeito de diferentes fatores em diferentes níveis de operação leva a uma busca de técnicas que reduzam o número de experimentos a serem empregados.

Em um planejamento experimental sugere-se para estudos que possuam como objetivo alcançar as condições otimizadas e que envolvam de 2 a 3 variáveis independentes, a realização de um delineamento composto central rotacional (DCCR), no caso de 4 a 8 variáveis independentes recomenda-se primeiramente a aplicação de fatoriais fracionados e/ou Plackett \& Burman para uma seleção dos efeitos estatisticamente significativos e de 9 a mais variáveis independentes é sugerido a aplicação do planejamento de Plackett \& Burman (47).

A Figura 5 apresenta uma estratégia sequencial das tomadas de decisão a serem seguidas de acordo com o número de fatores do estudo e objetivo.

Situação

Longe das condições

otimizadas

F Pouco conhecimento do processo Muitos fatores

\section{Objetivo}

Identificar as variáveis mais importantes

Planejamento

Fatorial Fracionado

Plackett \& Burman -PB

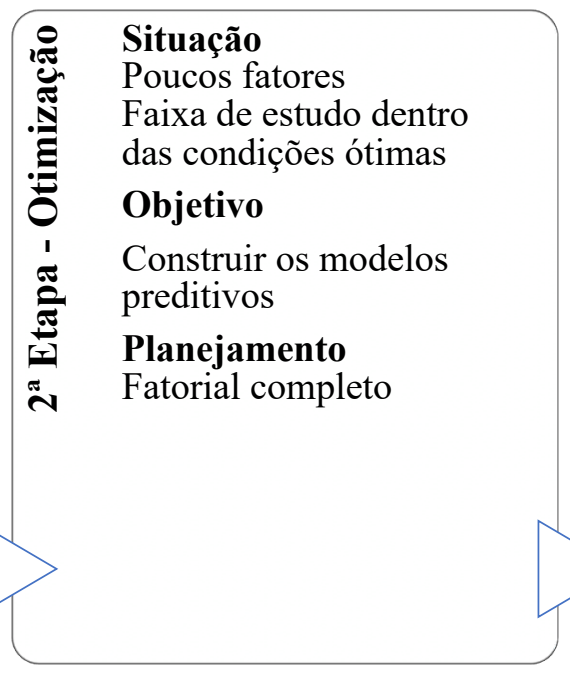

Figura 5 - Estratégia sequencial para tomadas de decisões.

Fonte: Adaptado de Rodrigues e lemma, 2014 (47)

Pode-se concluir que para alcançar a otimização de um processo é necessário a realização de um planejamento experimental composto de uma sequência de etapas interdependentes, formadas por fases de análise do processo e de análises estatísticas, somadas as boas práticas laboratoriais e o bom senso em todas as tomadas de decisão. A representação de todas as etapas presentes no processo de otimização está representada pela Figura 6. 


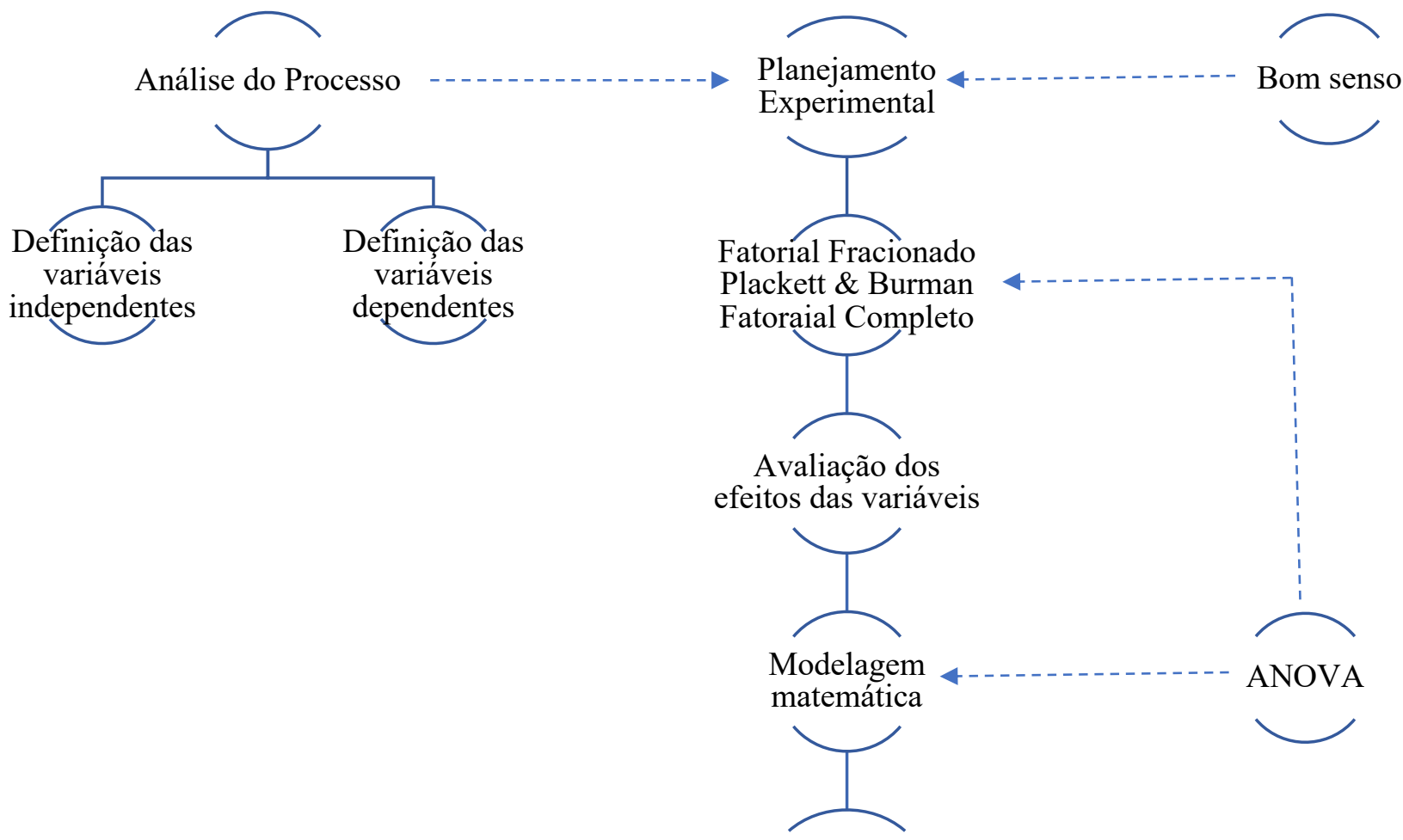

Análise das superfícies de resposta

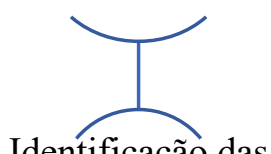

faixas ótimas de

operação

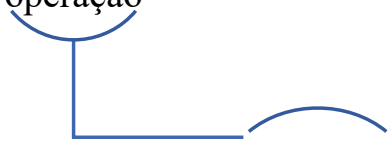

Validação experimental dos resultados

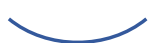

lura 6 - Etapas de um Planejamento Experimental e Otimização de Processos

Fonte: Adaptado de Rodrigues e lemma, 2014 (47)

\subsection{2. \\ Delineamento Composto Central Rotacional - DCCR}

De acordo com Montgomery (2013) o delineamento composto central rotacional, utilizado na presente dissertação, é a classe de delineamento mais difundida para modelos de segunda ordem.

Em grande parte dos casos, o planejamento DCCR é formado por um planejamento fatorial $2^{k}$ (ou fatorial fracionado), mais $2^{*} k$ pontos axiais, o que atribui a rotabilidade ao delineamento, e de 3 a 5 pontos centrais, onde $k$ representa o número de variáveis independentes do sistema. 
Os pontos pertencentes a parte cúbica são codificados para $( \pm 1)$, os pontos axiais codificados para $\pm \alpha$, onde $\alpha$ é dependente do número de pontos da porção fatorial do planejamento (como demonstrado na Tabela 6) , e o ponto central codificado para (0), onde as repetições deste ponto asseguram a estabilidade da predição da distribuição da variância.

Tabela 6 - Valor de a em função do número de fatores

$\begin{array}{ccc}\text { Número de Fatores }(k) & \text { Porção Fatorial } & \boldsymbol{\alpha} \\ 2 & 2^{2} & 1,41 \\ 3 & 2^{3} & 1,68 \\ 4 & 2^{4} & 2 \\ 5 & 2^{5} & 2,38 \\ 6 & 2^{6} & 2,83\end{array}$

Atribuir a rotabilidade a um delineamento, fornece a este a característica de precisão de estimação igual em todas as direções, portanto, de grande utilidade ao executar uma busca da localização do ponto ótimo, sendo este desconhecido antes da execução dos experimentos (48). A Figura 7 representa a esquematização de um DCCR com 3 fatores.
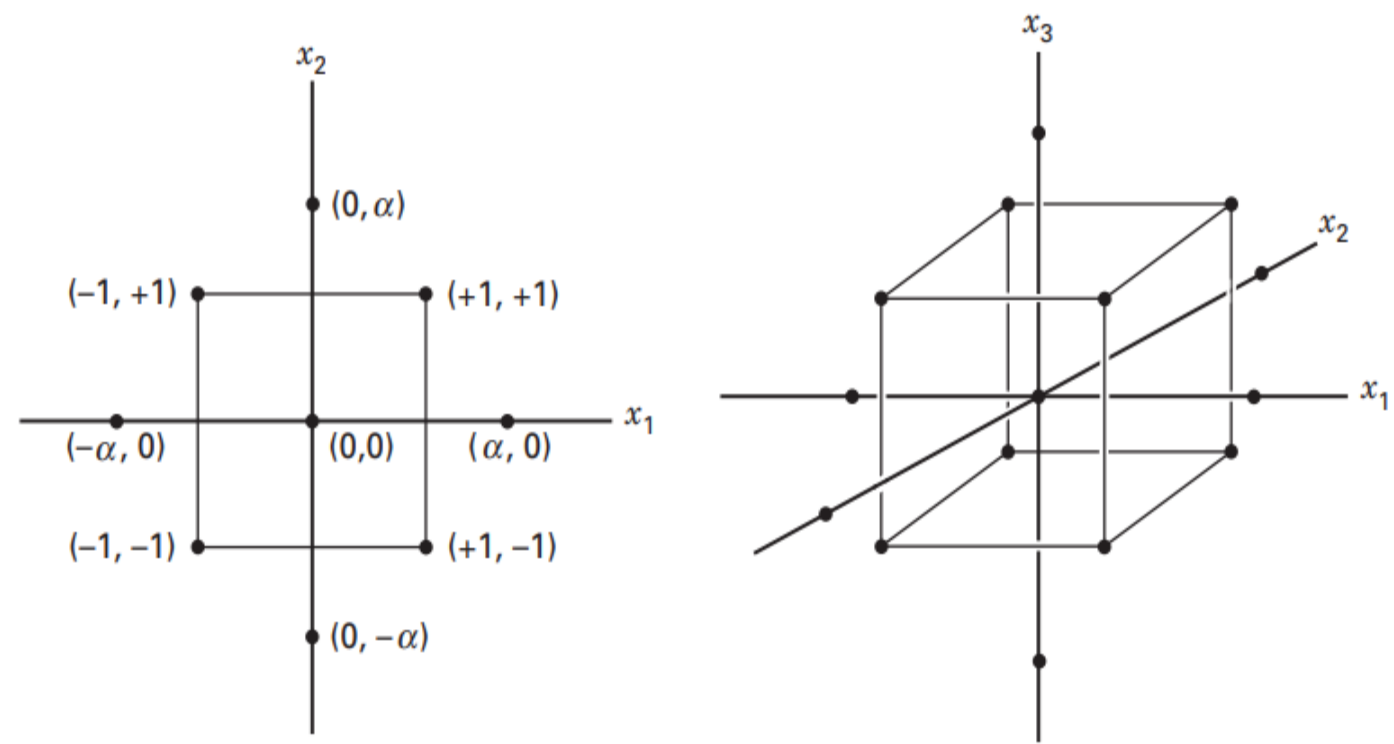

Figura 7 - Esquematização de um DCCR com 3 fatores.

Fonte: Montgomery, 2013 (48). 


\section{4 \\ Materiais e Métodos}

Neste capítulo são apresentados os materiais e os métodos que foram empregados no presente estudo, descrevendo a metodologia aplicada, os equipamentos e os reagentes utilizados, para a produção e caracterização da solução de sulfato férrico a partir de sulfato ferroso heptahidratado em apresentação sólida cristalina.

\section{1.}

\section{Materiais}

\subsection{1.}

Sistema para controle de oxidação e temperatura

Em uma bancada foi montado um sistema composto por: um béquer de 200 $\mathrm{mL}$, uma bureta graduada, para controle da quantidade e velocidade de adição do reagente oxidante; um eletrodo de ORP e um eletrodo de $\mathrm{pH}$, para posterior análise do potencial de redução da solução e controle do $\mathrm{pH}$ da mistura, respectivamente; um termômetro de vidro, para mensurar a temperatura da reação; um agitador magnético, para homogeneização do sistema reacional; um recipiente de plástico, para possibilitar a realização de um banho térmico, e assim, manter a reação nas faixas de temperatura de interesse; e um agitador rotatório para manter o banho térmico homogêneo durante toda a operação e facilitar o controle da temperatura reacional. A Figura 8 , representa esquematicamente 0 sistema montado em bancada. 


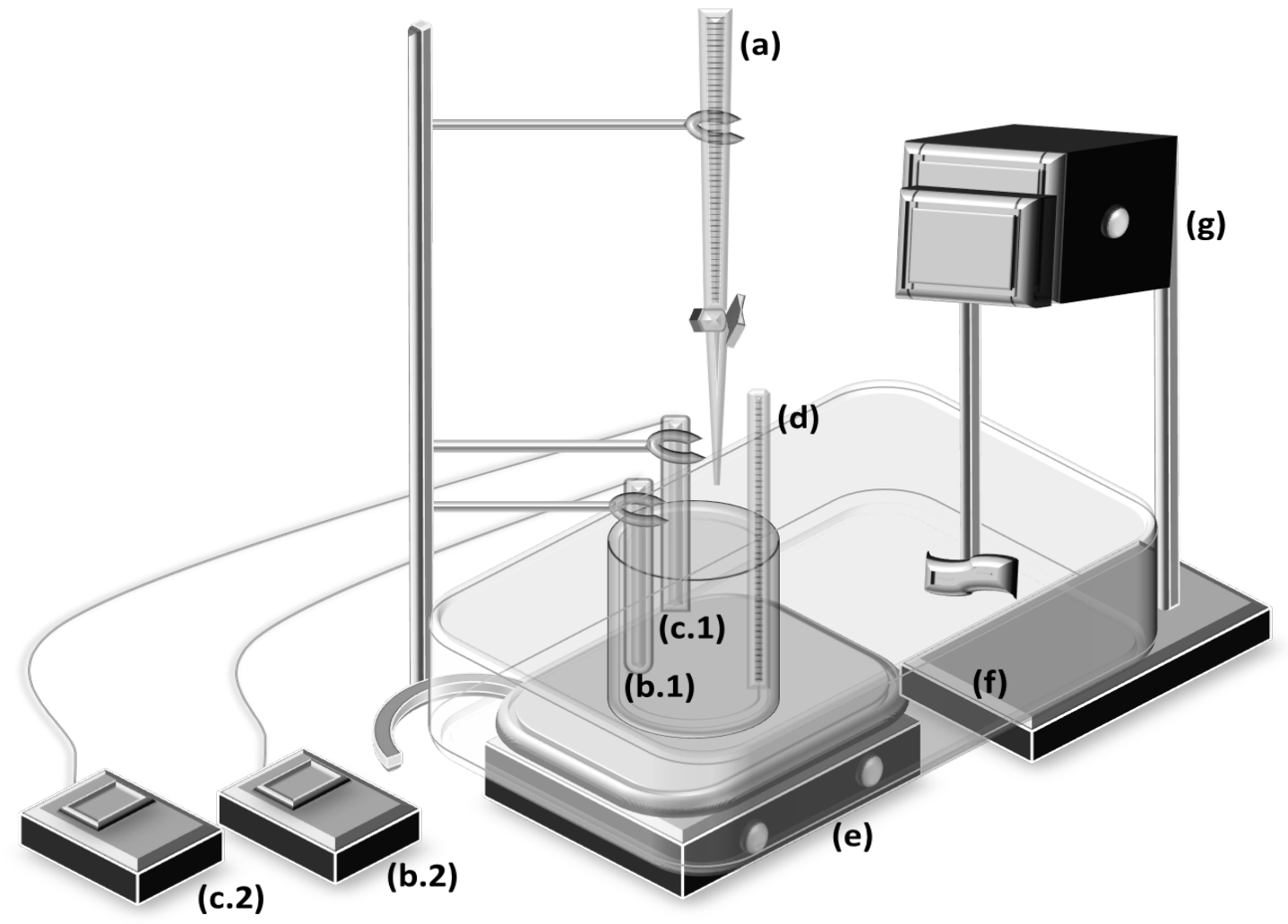

ura 8 - Sistema montado em bancada para controle de temperatura e oxidação. (a) Bureta graduada,

l) Eletrodo de pH, (b.2) Medidor de pH, (c.1) Eletrodo de ORP, (c.2) Medidor de ORP, (d) Termômetro de vidro,

Agitador magnético, (f) Recipiente de plástico e (g)Agitador mecânico de bancada.

Na Tabela 7 encontram-se as especificações de todos os componentes do sistema montado em bancada, para o controle da oxidação e temperatura, do meio reacional.

Tabela 7 - Especificações dos componentes do sistema montado em bancada

Componente

Especificações
1. Bureta graduada
(b.1) Eletrodo de $\mathrm{pH}$
(b.2) Medidor de $\mathrm{pH}$
(c.1) Eletrodo de ORP
(c.2) Medidor de ORP
(d) Termômetro de vidro
(e) Agitador magnético
(f) Recipiente de plástico
(g) Agitador mecânico de bancada
Bureta de vidro de $25 \mathrm{~mL}$
Eletrodo Hanna Instruments, Modelo HI11310
Marca Hanna Instruments, Modelo HI2020-01
Marca Hanna Instruments, Modelo HI3230B
Marca Hanna Instruments, Modelo HI4222
Coluna de mercúrio
Marca Asca S.A. 


\subsection{2.}

\section{Equipamentos analíticos}

Para o monitoramento da conversão de $\mathrm{Fe}^{2+}$ em $\mathrm{Fe}^{3+}$, ao longo do experimento, foi utilizado o colorímetro da marca $\mathrm{HACH}$, modelo DR900, em conjunto com os kits de reagentes específicos para cada tipo de leitura e cubetas de $25 \mathrm{~mL}$, próprias para utilização no equipamento.

Utilizou-se o reflectômetro Reflectoquant ${ }^{\circledR}$ da marca Merck, modelo RQflex® 10 , em conjunto com as tiras de teste Reflectoquant $₫$, específicas para quantificação de peróxido de hidrogênio em soluções, com limite de detecção de 0,2 - $20 \mathrm{mg} / \mathrm{L} \mathrm{H}_{2} \mathrm{O}_{2}$. Para um melhor controle de resultados, foi aplicado em conjunto o método colorimétrico semi-quantitativo, com faixa de detecção entre 0,5 - $25 \mathrm{mg} / \mathrm{L} \mathrm{H}_{2} \mathrm{O}_{2}$, utilizando tiras indicativas MQuant ${ }^{\mathrm{TM}}$ da marca Merck.

\subsection{3.}

\section{Reagentes}

Para a construção do meio reacional, foi utilizado água destilada e reagentes de grau analítico, sendo eles:

- Sulfato Ferroso Heptahidratado P.A.- A.C.S, da marca Synth;

- Ácido Sulfúrico 98\% P.A.- A.C.S, da marca Isofar;

- Peróxido de Hidrogênio 50\%, da marca Peróxidos do Brasil;

Os kits de reagentes utilizados, em conjunto com o equipamento colorimétrico, para a quantificação de $\mathrm{Fe}^{2+}$ e $\mathrm{Fe}_{\text {total, foram: }}$

- Kit Ferro Reagente Ferrous Iron, Powder Pillows

Método 1,10-Fenantrolina

Faixa de aplicação: 0,02 a 3,00 mg/L Fe ${ }^{2+}$

- Kit Ferro Reagente Total Iron, Powder Pillows

Método FerroVer®

Faixa de aplicação: 0,02 a 3,00 mg/L Fe total

Vale ressaltar que, ambos os kits e seus respectivos métodos de análise foram fundamentados no método código 3500-Fe B. do Standard Methods for the Examination of Water and Wastewater (49). 


\section{2.}

\section{Métodos}

\subsection{1. Produção de sulfato férrico}

Sabe-se que o sulfato férrico pode ser obtido através da reação entre sulfato ferroso, peróxido de hidrogênio e ácido sulfúrico. O meio de obtenção mais conhecido, utilizando estes reagentes, consiste primeiramente na solubilização do sulfato ferroso em meio ácido, formado pela da mistura de água e ácido sulfúrico, e em seguida pela oxidação de $\mathrm{Fe}^{2+}$ a $\mathrm{Fe}^{3+}$, através da adição de um agente oxidante, neste caso o peróxido de hidrogênio. A fórmula geral desta reação é:

$$
2 \mathrm{FeSO}_{4}+\mathrm{H}_{2} \mathrm{SO}_{4}+\mathrm{H}_{2} \mathrm{O}_{2}=\mathrm{Fe}_{2}\left(\mathrm{SO}_{4}\right)_{3}+2 \mathrm{H}_{2} \mathrm{O}
$$

Como citado anteriormente, a ação oxidante do peróxido de hidrogênio resulta em um processo altamente exotérmico, gerando um aumento da temperatura do meio reacional. $O$ evento de aumento da temperatura da reação proporciona um meio propício para a auto decomposição do agente oxidante em solução que ainda não havia reagido com o $\mathrm{Fe}^{2+}$, e, portanto, não exercendo seu papel de agente oxidante. Neste cenário, reações em cadeia de auto decomposição do peróxido de hidrogênio são incitadas, visto que a sua própria auto decomposição também é caracterizada pela alta liberação de calor. Deste modo, é necessário um excesso de peróxido de hidrogênio, já que grande parte se auto decompõe em água e oxigênio, e assim, dificultando a utilização deste reagente como agente oxidante devido ao alto custo que implicaria a sua utilização. Visando determinar condições reacionais que minimizem o processo de auto decomposição do peróxido de hidrogênio como agente oxidante na produção de sulfato férrico, foi proposto no presente estudo a análise da eficiência da ação oxidante do peróxido de hidrogênio em meios reacionais fixados em diferentes faixas de temperatura em conjunto com diferentes quantidades dos componentes químicos envolvidos, para assim, otimizar a produção do coagulante sulfato férrico, dentro dos padrões comerciais e com menor custo de produção.

O método de produção do coagulante férrico, em todas as etapas, consistiu na seguinte sequência

de passos:

$1^{\circ}$. Pesagem de 83,419 gramas de sulfato ferroso heptahidratado em balança analítica. 
$2^{\circ}$. Em um béquer de $200 \mathrm{~mL}$, dissolução dos cristais de sulfato ferroso heptahidratado com água destilada, sob agitação com o auxílio de bastão e agitador magnéticos.

$3^{\circ}$. Adição lenta de ácido sulfúrico $(98 \%)$ ao meio reacional.

$4^{\circ}$. Estabilização da solução na temperatura de interesse, com auxílio do sistema montado em bancada, através da inserção de água e gelo no recipiente de plástico e do funcionamento do agitador mecânico de bancada, em baixa velocidade.

$5^{\circ}$. Adição gradual de peróxido de hidrogênio (50\%), utilizando uma bureta graduada.

Devido à carência de estudos que indicassem o comportamento dos componentes químicos no meio reacional em questão dentro das condições operacionais propostas na presente dissertação, foram necessários testes preliminares para a identificação das faixas de operação aplicáveis a cada um dos reagentes. Para isto, foi empregado os conceitos de planejamento de experimentos e otimização de processos, seguindo a estratégia sequencial para tomadas de decisões, onde a primeira consistiu na seleção das variáveis e seus níveis a serem estudados. Para esta finalidade, as quantidades de cada reagente adicionado ao sistema obedeceram aos seus respectivos níveis propostos em cada tratamento, conforme apresentados nas Tabelas 8 e 9. A quantidade de sulfato ferroso heptahidratado foi fixada, visando a obtenção de uma solução final de volume igual a $100 \mathrm{~mL}$ com concentração de $\mathrm{Fe}_{\text {total }}$ equivalente a solução do coagulante sulfato férrico comercial com 167,6 $\mathrm{g} \mathrm{Fe}^{3+} / \mathrm{L}$ escolhido como modelo (50). As quantidades estequiométricas calculadas para os reagentes foram: $8 \mathrm{~mL}$ de $\mathrm{H}_{2} \mathrm{SO}_{4}(98 \%), 8,43 \mathrm{~mL}$ de $\mathrm{H}_{2} \mathrm{O}_{2}(50 \%)$ e $34,2 \mathrm{~mL}$ de $\mathrm{H}_{2} \mathrm{O}$.

As adições do agente oxidante foram feitas de forma particionada, onde cada parte equivaleu a $50 \%$ da quantidade estequiométrica. Por exemplo, se o nível de porcentagem estequiométrica de peróxido de hidrogênio adicionado à solução fosse igual a $250 \%$, seriam executadas 6 adições de volumes equivalentes a $50 \%$ da porcentagem estequiométrica de peróxido de hidrogênio. Desta forma, foi possível o recolhimento e análise de amostras ao longo da reação que viabilizaram um maior controle do progresso da reação de oxidação. 


\subsection{2.}

\section{Caracterização do coagulante sulfato férrico produzido}

Em todos os tratamentos, após cada partição de $\mathrm{H}_{2} \mathrm{O}_{2}$ adicionado, isto é $50 \%$ de sua quantidade estequiométrica, com o auxílio de uma micropipeta retirava-se uma amostra de $200 \mu \mathrm{L}$ da solução reacional e a armazenava em um béquer de $10 \mathrm{~mL}$. Para os tratamentos realizados em temperaturas abaixo de 25 ${ }^{\circ} \mathrm{C}$, posicionava-se o béquer com a amostra em um banho com água a aproximadamente a $25^{\circ} \mathrm{C}$. Quando a temperatura da amostra entrava em equilíbrio com a temperatura do banho e não apresentava mais liberação de oxigênio gasoso, retirava-se uma alíquota de $100 \mu \mathrm{L}$ da amostra e a diluía em um balão volumétrico de $50 \mathrm{~mL}$, com água destilada. Em seguida, retirava-se $100 \mu \mathrm{L}$ da amostra diluída e repetia o processo de diluição em um segundo balão volumétrico de $50 \mathrm{~mL}$.

Vale salientar que a avaliação das leituras obtidas pelo colorímetro $\mathrm{HACH}$ DR900, foram previamente testadas utilizando técnicas de espectrometria por ICP-OES e espectrofotometria UV/Vis.

Um outro ponto a ser comentado é que, para possibilitar a análise e comparação dos resultados obtidos pelas análises quantitativas, devido às condições estudadas envolverem excessos de reagentes, as respostas obtidas de concentração foram corrigidas para um volume de solução final igual a $100 \mathrm{~mL}$.

\subsubsection{1. Quantificação de $\mathrm{Fe}^{2+}$}

Utilizando uma micropipeta de $5 \mathrm{~mL}$, transferiu-se $25 \mathrm{~mL}$ da amostra obtida pela segunda diluição para um tubo Falcon. Em seguida, adicionou-se o conteúdo de um sachê reagente, referente ao método 1,10-Fenantrolina. Agitou-se o tubo com movimentos de inversão, até a diluição de todo o conteúdo do reagente. Após 3 minutos, tempo necessário para a completa reação, a solução apresentava uma coloração avermelhada, quando a amostra continha ferro II.

Utilizando o colorímetro HACH DR 900, programado em 255 Iron, Ferrous, lia-se o branco, contendo apenas água destilada utilizada nas diluições, e em seguida lia-se a solução contendo o reagente. 


\subsubsection{2.}

\section{Quantificação de Fe $e_{\text {total }}$}

Em uma cubeta de $25 \mathrm{~mL}$, diluiu-se o conteúdo de um sachê reagente, referente ao método FerroVer ${ }^{\circledR}$, com movimentos circulares, em $10 \mathrm{~mL}$ da amostra obtida pela segunda diluição e transferida através de uma micropipeta de $5 \mathrm{~mL}$. Após a 3 minutos, tempo necessário para a completa reação, a solução apresentava uma coloração alaranjada, indicando a presença de ferro.

Utilizando o colorímetro HACH DR 900, programado em 286 Iron FerroVer, lia-se o branco, contendo apenas água destilada utilizada nas diluições, e em seguida lia-se a solução contendo o reagente.

\subsection{3. \\ Quantificação de peróxido de hidrogênio residual}

Foi utilizado o método reflectométrico para a quantificação de peróxido de hidrogênio residual nas amostras. Devido a necessidade de a solução em análise não conter nenhuma coloração, para não haver interferências na quantificação, foi necessário diluir uma alíquota de $25 \mathrm{~mL}$ da primeira diluição, utilizada na caracterização de ferro, em um balão volumétrico de $50 \mathrm{~mL}$. Em seguida a amostra era transferida a um béquer de $50 \mathrm{~mL}$ e as fitas testes eram submergidas na solução, por dois segundos. Após este tempo retirava-se o excesso de líquido na fita e efetuava-se a leitura no equipamento Reflectoquant ${ }^{\circledR}$.

O método de avaliação dos resultados deu-se pela inserção de fitas/indicadores do método colorimétrico MQuant ${ }^{\mathrm{TM}}$ na mesma solução diluída por um segundo. Decorrido este tempo retirava-se o excesso de líquido na fita e após um intervalo de tempo de 15 segundos, efetuava-se a leitura do resultado por comparação visual da coloração contida na fita/indicador imergida com a escala de cores indicada.

\subsection{4. Conceitos gerais aplicados em análises estatísticas e metodologia estatística para tomada de decisões}

A seguir apresenta-se alguns termos fundamentais envolvidos nas técnicas de planejamento e análise e as ferramentas estatísticas aplicadas nas tomadas de decisões. 


\section{Variáveis}

Em uma análise, as variáveis são determinadas propriedades, de uma amostra ou população, que podem ser mensuradas, controladas ou manipuladas. Estas podem expressar valores quantitativos ou qualitativos e podem exercer papéis diferentes em uma análise, sendo estes:

- Variáveis dependentes: é a resposta objetivo de um estudo a ser descoberta/explicada, sendo esta passível a variações pelas variáveis independentes. Em uma mesma análise pode-se mensurar/determinar uma ou mais respostas.

- Variáveis independentes: são características envolvidas em uma análise a serem manipuladas e/ou controladas. A manipulação/ controle desta variável em diferentes condições busca identificar a relação desta com a variável resposta.

\section{Níveis das variáveis independentes}

As variáveis independentes devem ser manipuladas dentro de uma faixa de valores, onde tal faixa é dividida em $\mathrm{n}$ partições que variam de acordo com o procedimento estatístico a ser utilizado. Cada partição configura um nível.

\section{Tratamentos}

Cada tratamento consiste em variáveis independentes configuradas em diferentes combinações de níveis.

\section{Coeficiente de determinação ou explicação $\left(\mathbf{R}^{2}\right)$}

Grandeza que expressa a qualidade do ajustamento da reta de regressão à nuvem de pontos experimentais mensurados.

$O R^{2}$ é calculado da seguinte forma:

$$
R^{2}=\sum_{i=1}^{n}\left(\widehat{y}_{i}-y_{i}\right)^{2} / \sum_{i=1}^{n}\left(y_{i}-\bar{y}\right)^{2}
$$

Onde n é o número de observações, $y_{i}$ é o valor observado, $\bar{y}$ é a média das observações e $\widehat{y}_{l}$ é o valor estimado de $y_{i}$ pelo modelo matemático. 


\section{Coeficiente de determinação ou explicação ajustado ( $R^{2}$ ajustado)}

Grandeza que expressa a qualidade do ajustamento da reta de regressão à nuvem de pontos experimentais mensurados, ajustada ao número de preditores inclusos no modelo (51) (52).

$$
R_{\text {ajustado }}^{2}=1-(n-1)\left(1-R^{2}\right) /(n-k-1)
$$

Onde k representa o número de variáveis explicativas.

Observe que a inclusão de mais variáveis com pouco poder explicativo

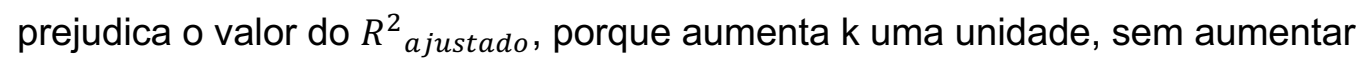
substancialmente o $R^{2}$.

\section{Estatisticamente significativo}

A significância estatística é uma medida para determinar o quanto os resultados obtidos são relevantes no estudo. Mais especificamente, o quanto os dados obtidos descrevem o comportamento/caracterizam a população, e, portanto, se estes ocorreriam ao acaso.

\section{p-Valor}

Seu valor representa a evidência para a rejeição da hipótese nula. Quanto menor esta grandeza, mais forte é a evidência da rejeição da hipótese nula, nos testes de hipóteses.

\section{Nível de significância ( $\alpha$ )}

É a probabilidade admitida para tomadas de decisões errôneas, isto é, quando se descarta a hipótese nula quando esta é verdadeira, nos testes de hipóteses.

\section{Teste de Hipóteses}

Este teste é definido como uma regra de decisão estatística que permite, com base em informações contidas nos dados amostrais (dados experimentais), concluir sobre parâmetros da população (conjunto formados por todos os fatores).

Afim de obtermos inferências sobre os parâmetros envolvidos que efetivamente afetam a conversão do $\mathrm{Fe}^{2+}$ em $\mathrm{Fe}^{3+}$, nos ensaios realizados para a presente tese, realizou-se o Teste de Hipóteses. A aplicação deste método 
utilizando os dados experimentais obtidos, permite estipular o modelo matemático o qual exprime o comportamento dos fatores do meio reacional em questão.

As hipóteses estatísticas, foram:

- Hipótese nula $\left(\mathrm{H}_{0}\right): \beta \mathrm{x}=0, \mathrm{x}=\{0, \mathrm{j}, \mathrm{ij}, \mathrm{jj}\}$

Onde avalia-se se há evidencias de algum coeficiente $\beta x$, linear ou quadrático, ser equivalente a zero e assim possa ser desprezado na construção da parametrização.

- Hipótese alternativa $\left(\mathrm{H}_{\mathrm{a}}\right): \beta \mathrm{x} \neq 0, \mathrm{x}=\{0, \mathrm{j}, \mathrm{ij}, \mathrm{jj}\}$

Realizando-se o teste bicaudal. Onde avalia-se se há evidencias de algum coeficiente $\beta x$, linear ou quadrático, ser diferente de zero e assim possa ser incluído na construção da parametrização.

\section{Análise de Variância (ANOVA)}

A ANOVA ou Análise de Variância foi realizada visando testar se de fato é possível considerar a regressão obtida, isto é, se o modelo possui capacidade preditiva, através da utilização do teste $F(52)$.

- Teste F

O teste $\mathrm{F}$ global é uma medida indicativa da significância do poder global exploratório, isto é, indica se o modelo matemático obtido como um todo é significante para a descrição da variável dependente.

A hipótese nula assume que o ajuste do modelo somente interceptado e o modelo matemático obtido são iguais. Portanto, a rejeição desta hipótese indica que há uma relação estatisticamente significante entre pelo menos uma das variáveis independentes e a variável dependente. 


\section{5 \\ Resultados e Discussão}

5.1.

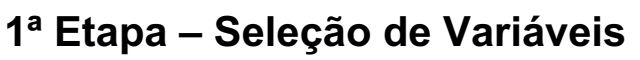

$\mathrm{Na}$ fase inicial do projeto experimental, foi feito um processo de triagem das variáveis independentes do processo. Foram realizados testes visando identificar as possíveis variáveis independentes e os níveis aplicáveis a estas, através da avaliação da eficiência do processo de oxidação pelo peróxido de hidrogênio e da estabilidade do produto final. Nesta primeira etapa, devido à então indisponibilidade dos reagentes para as análises quantitativas, a eficiência da redução foi avaliada por meio da percepção visual de precipitados residuais (cristais de sulfato ferroso) e da coloração da solução final frente a coloração característica do coagulante sulfato férrico em forma líquida. A estabilidade do coagulante produzido foi avaliada pela observação da formação ou não de precipitados com o decorrer do tempo, estabelecido em 1 mês após finalização do experimento.

\section{- $\quad$ Primeira triagem de variáveis}

Nesta primeira triagem, as variáveis estudadas foram a temperatura e os elementos envolvidos no meio reacional proposto, sendo estes, o peróxido de hidrogênio, a água e o ácido sulfúrico.

Devido ao pouco conhecimento sobre as faixas de operação das variáveis respectivas aos componentes químicos envolvidos no processo de oxidação, que viabilizariam conversões satisfatórias e a relação dessas variáveis no processo, foi posto em teste os níveis estequiométricos de cada reagente e excessos destes próximos dos aceitáveis e excessos acima dos aceitáveis, em termos econômicos com base em uma produção em escala industrial.

Em virtude da alta liberação de calor, provocada pelas reações envolvidas no estudo, em conjunto com as condições operacionais dos experimentos, impostas pelos equipamentos disponíveis, tornou-se impraticável conservar a 
temperatura do meio reacional em um valor específico e, portanto, adotou-se faixas de temperaturas, cada uma com uma variação máxima de $5^{\circ} \mathrm{C}$.

Outra consequência da então indisponibilidade dos kits durante a etapa de seleção de variáveis, foi a não efetuação de um planejamento DCCR ou um fatorial fracionado, como é sugerido em estudos para otimização de processos, e também não foi estudado um nível intermediário entre as faixas de temperaturas estipuladas, visto que não seria possível identificar pequenas variações na eficiência de redução. Diante de tais condições e sem o conhecimento prévio das faixas de operações aplicáveis para as condições desejadas, foi realizado um planejamento similar a um planejamento fatorial fracionado, para a obtenção de maiores conhecimentos sobre o processo e para a identificação das variáveis e seus respectivos níveis a serem estudados. A Tabela 8 exibe a os níveis estudados na primeira triagem das variáveis.

Tabela 8 - Níveis utilizados na primeira triagem das variáveis.

Variáveis

Porcentagem estequiométrica de

Peróxido de Hidrogênio $\left(\mathrm{H}_{2} \mathrm{O}_{2}\right)$

Porcentagem estequiométrica de

Ácido Sulfúrico $\left(\mathrm{H}_{2} \mathrm{SO}_{4}\right)$

Porcentagem estequiométrica de $\operatorname{Agua}\left(\mathrm{H}_{2} \mathrm{O}\right)$

Faixa de temperatura do processo $\left({ }^{\circ} \mathrm{C}\right)$
Código

Niveis

\begin{tabular}{|cccc} 
& -1 & 0 & +1 \\
$\mathrm{X} 1$ & $100 \%$ & $200 \%$ & $500 \%$ \\
$\mathrm{X} 2$ & $100 \%$ & $200 \%$ & $500 \%$ \\
$\mathrm{X} 3$ & $100 \%$ & $200 \%$ & $500 \%$ \\
$\mathrm{X} 4$ & $10-15$ & - & $25-30$
\end{tabular}

A Tabela 9 exibe os tratamentos feitos e os resultados das análises de avaliação da eficiência do processo de oxidação e da estabilidade do produto final, na primeira triagem das variáveis. 
Tabela 9 - Valores codificados e respostas da eficiência na redução e estabilidade na primeira triagem de variáveis.

\begin{tabular}{c|cccccc}
\multirow{2}{*}{ Tratamentos } & \multicolumn{4}{c}{ Niveis } & \multicolumn{1}{c}{$\begin{array}{c}\text { Eficiência na } \\
\text { oxidação }\end{array}$} & Estabilidade \\
\cline { 2 - 4 } 1 & $\mathbf{X 1}$ & $\mathbf{X 2}$ & $\mathbf{X 3}$ & $\mathbf{X 4}$ & Não & Não \\
2 & -1 & -1 & -1 & -1 & Não & Não \\
3 & -1 & -1 & -1 & 1 & Sim & Sim \\
4 & -1 & -1 & 1 & -1 & Sim & Sim \\
5 & -1 & -1 & 1 & 1 & Não & Não \\
6 & -1 & 1 & -1 & -1 & Não & Não \\
7 & -1 & 1 & -1 & 1 & Sim & Sim \\
8 & 1 & -1 & -1 & -1 & Sim & Sim \\
9 & 1 & -1 & -1 & 1 & Sim & Sim \\
10 & 0 & -1 & -1 & -1 & Sim & Sim \\
11 & 0 & -1 & -1 & 1 & Não & Não \\
12 & -1 & 0 & -1 & -1 & Não & Não
\end{tabular}

Nos ensaios onde todas as variáveis se encontravam em proporções estequiométricas, tratamentos 1 e 2, em ambas condições de temperatura, foi possível verificar a presença de precipitados ao final da reação e ao final de dois meses verificou-se a instabilidade da solução final produzida, devido a formação de um cristal verde ao fundo do tubo Falcon. Pode-se então concluir que não foi possível obter uma conversão satisfatória, quando as variáveis estudadas foram adicionadas em níveis estequiométricos, mesmo que para duas temperaturas diferentes.

Verificou-se que, entre todas as variáveis a única que não foi benéfica ao processo foi o ácido sulfúrico quando em excesso, pois, nas análises onde este reagente se encontrou com magnitude equivalente a $200 \%$ de sua quantidade estequiométrica, tratamentos 11 e 12 , foi possível identificar a presença de precipitados e, portanto, evidenciando que esta condição de excesso de ácido sulfúrico no meio não propicia condições favoráveis para a redução total do sulfato ferroso adicionado ao sistema e ao decorrer de um mês verificou-se a formação de um cristal verde ao fundo do tubo Falcon, cor característica dos cristais de sulfato ferroso, o que corroborou para afirmação inicialmente feita. Na presença 
de excesso de $400 \%$ de ácido sulfúrico, tratamentos 5 e 6 , em temperatura ambiente $\left(25^{\circ} \mathrm{C}-30^{\circ} \mathrm{C}\right)$, formou-se uma solução pastosa cinza-esverdeada, e em condição de baixa temperatura operacional a solução final caracterizava-se pela cor esverdeada e com alta turbidez. Ao final de um mês verificou-se a precipitação de um material particulado esverdeado ao fundo do tubo Falcon, novamente evidenciando que tal condição de excesso de ácido sulfúrico no meio não propicia condições favoráveis para a redução total do sulfato ferroso adicionado ao sistema.

A Figura 9 exibe o cristal verde formado, caracterizando a deposição de sulfato ferroso.

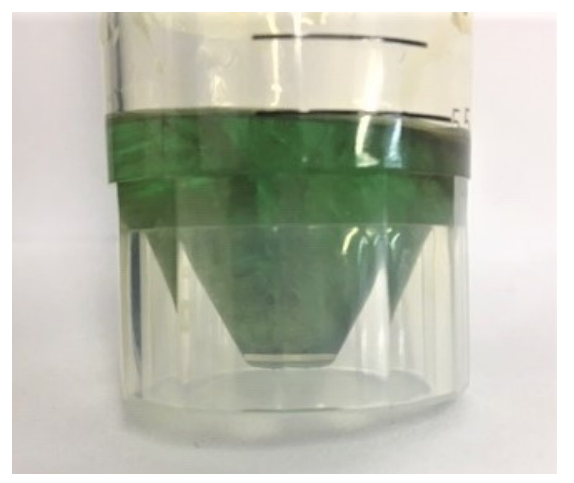

Figura 9 - Cristal de sulfato ferroso formado

- Segunda triagem de variáveis

Com base nas análises preliminares, a utilização do ácido sulfúrico como uma das variáveis a ser estudada como independente no processo foi descartada, visto que o excesso deste reagente não favoreceu a conversão do $\mathrm{Fe}^{2+} \mathrm{em} \mathrm{Fe}^{3+}$, sendo assim, a sua quantidade para a segunda triagem de variáveis foi fixada na quantidade estequiométrica. Vale frisar que uma grande quantidade deste reagente adicionado à reação poderia resultar em um indesejável excesso de acidez no produto final, portanto, utilização deste reagente em quantidade estequiométrica não influencia negativamente na obtenção de um coagulante férrico dentro dos requisitos previstos por lei.

Uma outra observação durante a primeira triagem, foram as conversões satisfatórias de $\mathrm{Fe}^{2+} \mathrm{em} \mathrm{Fe}^{3+}$, nos diferentes tratamentos em ambas as faixas de temperatura. Desta forma, visando avaliar como as baixas e controladas temperaturas influenciavam o processo, foram feitas análises avaliando a 
factibilidade da realização de um processo de oxidação satisfatório em uma faixa de temperatura mais baixa que a menor faixa anteriormente investigada.

Em busca de condições economicamente viáveis para a realização do processo em larga escala, foram feitos ensaios com adições em menores quantidades de agente oxidante e solvente, peróxido de hidrogênio e água respectivamente.

A Tabela 10 exibe a os novos níveis estudados na segunda triagem das variáveis.

Tabela 10 - Níveis utilizados na segunda triagem das variáveis

Fatores

Porcentagem estequiométrica de

Peróxido de Hidrogênio $\left(\mathrm{H}_{2} \mathrm{O}_{2}\right)$

Porcentagem estequiométrica de Água $\left(\mathrm{H}_{2} \mathrm{O}\right)$

Faixa de temperatura do processo $\left({ }^{\circ} \mathrm{C}\right)$
Código

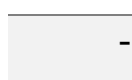

$\mathrm{X} 1$

$100 \%$

$\mathrm{X} 2$

$\mathrm{X} 3$

$-1$

Niveis

0

$+1$

$200 \% \quad 300 \%$

$100 \% \quad 200 \% \quad 300 \%$

$5-10 \quad 10-15 \quad 25-30$

A Tabela 11 exibe os resultados das análises de avaliação da eficiência do processo de oxidação através da adição do peróxido de hidrogênio e da estabilidade do produto final, na segunda triagem das variáveis.

Tabela 11 - Valores codificados e respostas da eficiência na redução e estabilidade na segunda triagem de variáveis

\begin{tabular}{|c|c|c|c|c|c|}
\hline \multirow{2}{*}{ Tratamentos } & \multicolumn{3}{|c|}{ Niveis } & \multirow{2}{*}{$\begin{array}{c}\text { Eficiência na } \\
\text { Oxidação }\end{array}$} & \multirow[t]{2}{*}{ Estabilidade } \\
\hline & $\mathrm{X} 1$ & $\mathrm{X} 2$ & X3 & & \\
\hline 1 & 0 & -1 & 1 & Sim & Sim \\
\hline 2 & -1 & 0 & 1 & Sim & Sim \\
\hline 3 & -1 & 1 & 1 & Sim & Sim \\
\hline 4 & 1 & -1 & 1 & Sim & Sim \\
\hline 5 & -1 & 1 & -1 & Sim & Sim \\
\hline 6 & -1 & 0 & -1 & Sim & Sim \\
\hline 7 & 0 & -1 & -1 & Sim & Sim \\
\hline 8 & 1 & -1 & -1 & Sim & Sim \\
\hline
\end{tabular}

Nesta segunda fase exploratória, em todos os ensaios realizados, as novas condições estipuladas para o sistema resultaram em respostas satisfatórias pelas 
análises visuais e de estabilidades das soluções finais, indicando uma aparente reação de oxidação completa. Portanto, baseando-se nos resultados obtidos na primeira e na segunda triagem das variáveis e seus níveis de operação, foi possível determinar os limites operacionais dos fatores a serem estudados na segunda etapa do planejamento experimental.

Vale ressaltar que após a disponibilização dos kits de análise de $\mathrm{Fe}^{2+}$ e $\mathrm{Fe}_{\text {total }}$ em conjunto com a medida do potencial de oxirredução, foram feitos testes para avaliar se o tempo de residência do peróxido de hidrogênio em solução afetava a eficiência da conversão de $\mathrm{Fe}^{2+}$ em $\mathrm{Fe}^{3+}$. Verificou-se a quantidade de $\mathrm{Fe}^{2+}$ em intervalos de tempo de 5, 10, 15 e 30 minutos, após cada adição de $50 \%$ da quantidade estequiométrica de peróxido. Em todas as análises a quantidade de $\mathrm{Fe}^{2+}$ e o potencial de oxirredução medido mantiveram-se estáveis, indicando que a reação é virtualmente instantânea e, portanto, não sendo necessário tempos superiores a 5 minutos para atingir a conversão máxima de $\mathrm{Fe}^{2+} \mathrm{em} \mathrm{Fe}^{3+}$ a cada partição adicionada de peróxido de hidrogênio. Desta forma, o tempo de cada ensaio foi influenciado pela capacidade de estabilização da temperatura dentro da faixa requerida, ao longo do processo de oxidação, com auxílio do sistema montado em bancado.

\section{- Elaboração do Procedimento Experimental}

Com a definição das variáveis independentes e seus respectivos níveis de estudo, foi possível determinar a estratégia e o planejamento a ser implementado no Procedimento Experimental. Uma vez que, as análises iniciais indicaram a possibilidade da existência de 3 variáveis independentes no processo, aponta-se a necessidade de utilizar um planejamento de Delineamento Composto Central Rotacional, com estratégia total de 17 pontos $\left(2^{3}+3\right.$ pontos centrais $+2^{*} 3$ pontos axiais).

O procedimento proposto necessita de seis níveis para cada um dos três fatores selecionados, determinados a partir dos resultados obtidos nos processos de triagem. Os fatores envolvidos no processo de experimentação e os níveis de ajuste apresentam-se na Tabela 12. 
Tabela 12 - Fatores, códigos e níveis do experimento realizado

\begin{tabular}{|c|c|c|c|c|c|c|}
\hline \multirow[t]{2}{*}{ Fatores } & \multirow[t]{2}{*}{ Código } & \multicolumn{5}{|c|}{ Niveis } \\
\hline & & 1,68 & -1 & 0 & +1 & $+1,68$ \\
\hline $\begin{array}{l}\text { Porcentagem estequiométrica } \\
\text { de Peróxido de Hidrogênio } \\
\left(\mathrm{H}_{2} \mathrm{O}_{2}\right)\end{array}$ & $\mathrm{X} 1$ & $100 \%$ & $150 \%$ & $200 \%$ & $250 \%$ & $300 \%$ \\
\hline $\begin{array}{l}\text { Porcentagem estequiométrica } \\
\text { de Água }\left(\mathrm{H}_{2} \mathrm{O}\right)\end{array}$ & $\mathrm{X} 2$ & $100 \%$ & $150 \%$ & $200 \%$ & $250 \%$ & $300 \%$ \\
\hline $\begin{array}{l}\text { Faixa de temperatura do } \\
\text { processo em }{ }^{\circ} \mathrm{C}\end{array}$ & $\mathrm{X} 3$ & $5-10$ & $10-15$ & $15-20$ & $20-25$ & $25-30$ \\
\hline
\end{tabular}

Vale ressaltar que o excesso de água adicionado ao sistema pelo reagente peróxido de hidrogênio não foi contabilizado na variável água, visto que este excesso representa uma fração mínima do volume total da solução, variando entre 0 e 0,06 .

\section{2. \\ Otimização do processo}

A matriz experimental e os resultados obtidos a partir do planejamento estão apresentados na Tabela 13.

Para permitir a modelagem matemática, foi necessário utilizar para os níveis da variável temperatura o valor médio de cada faixa de variação de temperatura. 
Tabela 13 - Matriz experimental e resultados obtidos

\begin{tabular}{|c|c|c|c|c|c|c|c|}
\hline \multirow{3}{*}{ Tratamentos } & \multicolumn{6}{|c|}{ Níveis } & \multirow{3}{*}{$\begin{array}{c}\text { Resposta } \\
\text { Conversão } \\
\mathrm{Fe}^{2+\rightarrow} \mathrm{Fe}^{3+} \\
(\%)\end{array}$} \\
\hline & \multicolumn{3}{|c|}{$\begin{array}{c}\text { Variáveis em unidades } \\
\text { codificadas }\end{array}$} & \multicolumn{3}{|c|}{$\begin{array}{c}\text { Variáveis em } \\
\text { unidades originais * }\end{array}$} & \\
\hline & $\mathrm{X} 1$ & $\mathrm{X} 2$ & X3 & $\begin{array}{c}\mathrm{H}_{2} \mathrm{O}_{2} \\
(\%)\end{array}$ & $\begin{array}{r}\mathrm{H}_{2} \mathrm{O} \\
(\%)\end{array}$ & $\begin{array}{l}\text { temp. } \\
\left({ }^{\circ} \mathrm{C}\right)\end{array}$ & \\
\hline 1 & -1 & -1 & -1 & 150 & 150 & 12,5 & 97,96 \\
\hline 2 & 1 & -1 & -1 & 250 & 150 & 12,5 & 98,15 \\
\hline 3 & -1 & 1 & -1 & 150 & 250 & 12,5 & 98,51 \\
\hline 4 & 1 & 1 & -1 & 250 & 250 & 12,5 & 98,51 \\
\hline 5 & -1 & -1 & 1 & 150 & 150 & 22,5 & 97,58 \\
\hline 6 & 1 & -1 & 1 & 250 & 150 & 22,5 & 100,00 \\
\hline 7 & -1 & 1 & 1 & 150 & 250 & 22,5 & 95,73 \\
\hline 8 & 1 & 1 & 1 & 250 & 250 & 22,5 & 95,64 \\
\hline 9 & $-1,68$ & 0 & 0 & 100 & 200 & 17,5 & 92,19 \\
\hline 10 & 1,68 & 0 & 0 & 300 & 200 & 17,5 & 99,49 \\
\hline 11 & 0 & $-1,68$ & 0 & 200 & 100 & 17,5 & 97,80 \\
\hline 12 & 0 & 1,68 & 0 & 200 & 300 & 17,5 & 95,22 \\
\hline 13 & 0 & 0 & $-1,68$ & 200 & 200 & 7,5 & 100,00 \\
\hline 14 & 0 & 0 & 1,68 & 200 & 200 & 27,5 & 97,21 \\
\hline 15 & 0 & 0 & 0 & 200 & 200 & 17,5 & 98,14 \\
\hline 16 & 0 & 0 & 0 & 200 & 200 & 17,5 & 98,18 \\
\hline 17 & 0 & 0 & 0 & 200 & 200 & 17,5 & 97,94 \\
\hline
\end{tabular}

( ${ }^{*} \mathrm{H}_{2} \mathrm{O}_{2}$ e $\mathrm{H}_{2} \mathrm{O}$ em \% referentes às suas respectivas quantidades estequiométricas

A análise matemática foi realizada com o auxílio do software estatístico Statistica versão 13 , da seguinte forma: (I) gerar o perfil para a estimação dos efeitos das variáveis; (II) identificar estatisticamente através do teste de hipóteses e diagrama de Pareto quais destas variáveis são significativas para a parametrização do modelo; (III) verificar a implicação da não inclusão dos coeficientes das variáveis identificadas como não significativas na parametrização, utilizando o teste de hipóteses, a Variação Explicada $\left(R^{2}\right)$ e a

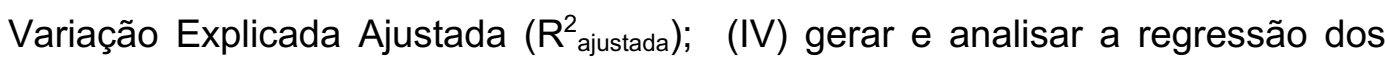
coeficientes para a parametrização; (V) realizar a ANOVA (Análise da Variância) para a verificação da qualidade de ajuste do modelo, utilizando o Teste F; (VI) gerar os perfis de superfície de resposta e curvas de contorno para a identificação do ponto ótimo; e (VII) validar experimentalmente os resultados matemáticos obtidos.

Todas as análises estatísticas foram realizadas considerando o nível de significância a igual a $10 \%$. 
A partir dos dados das variáveis independentes e das respostas obtidas pelos experimentos, apresentados na Tabela 13, obteve-se a estimação dos efeitos das variáveis, conforme apresentado na Tabela 14 abaixo.

Os perfis dos efeitos e dos coeficientes obtidos pelo software Statistica encontram-se no Anexo 9.2

Tabela 14 - Análise dos efeitos.

\begin{tabular}{|c|c|c|c|c|c|c|}
\hline \multirow[b]{2}{*}{ Fatores } & \multirow[b]{2}{*}{ Efeito } & \multirow[b]{2}{*}{ Erro Padrão } & \multirow[b]{2}{*}{ tcalc (7) } & \multirow[b]{2}{*}{ p - Valor } & \multicolumn{2}{|c|}{$\begin{array}{l}\text { Estimativas por } \\
\text { intervalo de } \\
\text { confiança }(90 \%)\end{array}$} \\
\hline & & & & & $\begin{array}{l}\text { Limite } \\
\text { Inferior }\end{array}$ & $\begin{array}{l}\text { Limite } \\
\text { Superior }\end{array}$ \\
\hline Média & 98,030 & 0,8354 & 117,35 & 0,0000 & 96,45 & 99,61 \\
\hline $\mathrm{H}_{2} \mathrm{O}_{2}(\mathrm{~L})$ & 2,166 & 0,7851 & 2,759 & 0,0282 & 0,678 & 3,653 \\
\hline $\mathrm{H}_{2} \mathrm{O}_{2}$ (Q) & $-1,216$ & 0,8649 & $-1,406$ & 0,2025 & $-2,855$ & 0,423 \\
\hline $\mathrm{H}_{2} \mathrm{O}(\mathrm{L})$ & $-1,413$ & 0,7851 & $-1,800$ & 0,1149 & $-2,900$ & 0,074 \\
\hline $\mathrm{H}_{2} \mathrm{O}_{2}(\mathbf{Q})$ & $-0,740$ & 0,8649 & $-0,855$ & 0,4207 & $-2,378$ & 0,899 \\
\hline Temperatura (L) & $-1,300$ & 0,7851 & $-1,656$ & 0,1417 & $-2,787$ & 0,187 \\
\hline Temperatura (Q) & 0,746 & 0,8649 & 0,862 & 0,4170 & $-0,893$ & 2,384 \\
\hline $\mathrm{H}_{2} \mathrm{O}_{2} \times \mathrm{H}_{2} \mathrm{O}$ & $-0,676$ & 1,025 & $-0,659$ & 0,5307 & $-2,618$ & 1,266 \\
\hline $\mathrm{H}_{2} \mathrm{O}_{2 \times}$ Temperatura & 0,534 & 1,025 & 0,521 & 0,6183 & $-1,408$ & 2,477 \\
\hline $\mathrm{H}_{2} \mathrm{O}_{x}$ Temperatura & $-1,782$ & 1,025 & $-1,738$ & 0,1258 & $-3,724$ & 0,160 \\
\hline
\end{tabular}

variação explicada $\left(R^{2}\right)=75,61 \%$, variação explicada ajustada $\left(R_{\text {ajustada }}^{2}\right)=44,25 \%$

Através da avaliação do p-Valor calculado e do nível de significância, determinou-se os parâmetros estatisticamente não significativos e assim a avaliação da não inclusão de seus coeficientes na parametrização. Admite-se através do método de hipóteses pelo $p$-Valor dos efeitos que os fatores que obtiveram $p$-Valor significantemente maiores que $\alpha=10 \%=0,1$ não apresentam nível de significância para o modelo, sendo estes: Porcentagem estequiométrica de Água Quadrática; Faixa de Temperatura do Processo Quadrática; Porcentagem estequiométrica de Peróxido de Hidrogênio Linear*Porcentagem estequiométrica de Água Linear; e Porcentagem estequiométrica de Peróxido de Hidrogênio Linear*Faixa de temperatura do processo Linear. Desta forma, não é possível rejeitar a hipótese de nulidade para os efeitos avaliados como não significativos.

A Figura 10 abaixo ilustra a análise gráfica de Pareto na qual é possível identificar visualmente a grandeza da significância dos efeitos, onde $t_{\text {tab }}=t_{(7 ; 10 \% / 2)}$ é representado pela reta vertical vermelha, a qual fornece um limite a partir do qual os efeitos podem ser considerados significativos. 


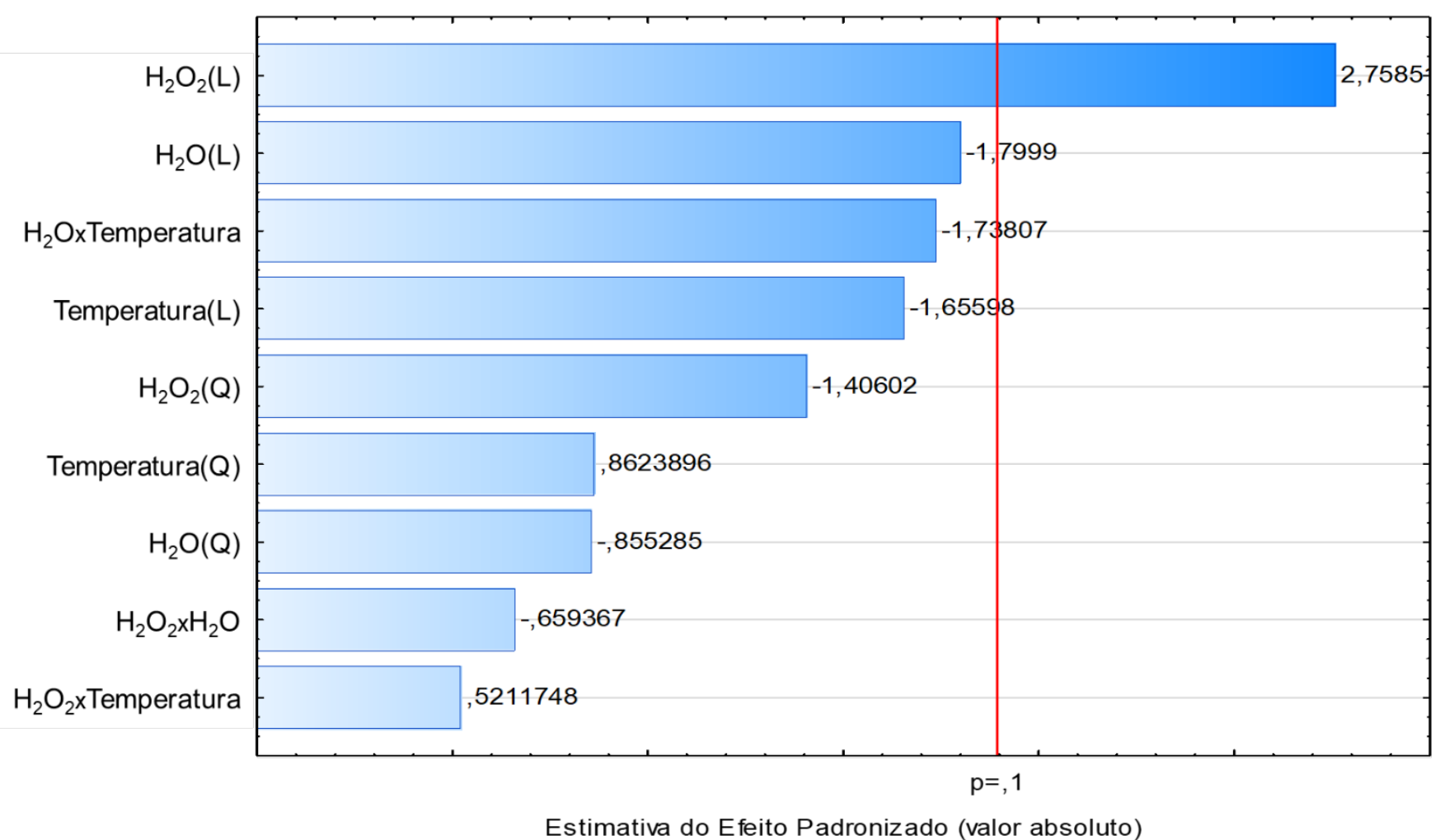

Figura 10 - Diagrama de Pareto.

A retirada dos fatores não significativos ocorreu da seguinte forma: (i) identificação e retirada do fator com maior p-Valor; (ii) geração de um novo perfil para os efeitos; e (iii) análise do $\mathrm{R}^{2}$ e $\mathrm{R}^{2}$ ajustado do novo perfil dos efeitos.

$\mathrm{O}$ procedimento de retirada um a um dos fatores menos significativos sucedeu-se até o momento onde foi verificado que a retirada destes não se apresentava benéfica à modelagem.

A Tabela 15 exibe os coeficientes de determinação $\left(R^{2}\right)$ e os coeficientes de determinação ajustados ( $\mathrm{R}^{2}$ ajustado $)$ obtidos antes e após cada retiradas dos fatores identificados como não significativos. Todos os perfis de respostas obtidos pelo Statistica apresentam-se no Anexo 9.2.1.

Tabela 15 - Coeficientes de determinação $R^{2}$ e $R^{2}$ ajustado.

Todos as variáveis inclusas

$\mathrm{R}^{2} \quad \mathrm{R}^{2}$ ajustado

Retirada do fator de interação $\mathrm{H}_{2} \mathrm{O}_{2} \times$ Temp.

$75,61 \%$ $44,25 \%$

Retirada do fator de interação $\mathrm{H}_{2} \mathrm{O}_{2} \times \mathrm{H}_{2} \mathrm{O}$

$74,66 \%$ $49,32 \%$

Retirada do fator $\mathrm{H}_{2} \mathrm{O}(\mathrm{Q})$

$73,15 \%$ $52,26 \%$

Retirada do fator Temperatura (Q) $70,60 \%$ $52,96 \%$

Retirada do fator $\mathrm{H}_{2} \mathrm{O}_{2}(\mathrm{Q})$ $65,86 \%$ $50,34 \%$ $57,90 \%$ $43,85 \%$ 
Ao realizar a estimação dos efeitos sem incorporação dos fatores identificados como não significativos, espera-se um decaimento natural do coeficiente de determinação $\left(R^{2}\right)$ devido à não inclusão de determinados fatores pois, quanto maior o número de preditores maior será o $\mathrm{R}^{2}$ do modelo. Porém, neste estudo a cada retirada de fatores observou-se um significativo decaimento do valor do coeficiente de determinação, como exibido na Tabela 15.

É possível deduzir que o decaimento expressivo do $R^{2}$ nas diferentes regressões feitas para o modelo é ocasionado pelo fato de que em todos os ensaios foi possível obter elevadas conversões, fazendo com que a proximidade das respostas dificultasse a modelagem dos dados. Apesar das diferentes condições experimentais não houve mudança significativa na resposta coletada, fazendo com que a retirada de qualquer coeficiente mesmo analisado como não estatisticamente significativo implicasse em notáveis mudanças na variação da resposta que é explicada pelo modelo matemático.

Desta forma, conclui-se que a faixa na qual as condições foram impostas ao processo, de temperatura, diluição e quantidade de peróxido de hidrogênio adicionado, proporcionaram altas conversões, não havendo significativas alterações na resposta colhida. Assim sendo, é possível deduzir que para observar maiores perturbações na resposta, seria necessário o estudo da conversão utilizando diferentes níveis dos estudados.

Analisou-se em conjunto os coeficientes de determinação ajustados $\left(R^{2}\right.$ ajustado), já que este coeficiente se apresenta como um melhor parâmetro de comparação para modelos envolvendo diferentes números de preditores. Observa-se uma pequena melhora no coeficiente $R_{\text {ajustado quando ocorre a }}^{2}$ primeira retirada dos três primeiros fatores identificados como não estatisticamente significativos, levando a conclusão de que de fato não se deve incluir o coeficiente quadrático referente a água no processo e os coeficientes de interação entre o peroxido de hidrogênio e a água e entre o peroxido de hidrogênio e a temperatura. O decaimento do $\mathrm{R}^{2}$ ajustado nos demais ajustes indica que o efeito quadrático referente a temperatura e ao peróxido de hidrogênio fornecem subsídios importantes para a formulação das respostas, e, portanto, a retirada deste afeta significativamente de forma negativa a parametrização do modelo.

Em seguida, calculou-se os coeficientes de regressão, apresentados na Tabela 16, com as variáveis analisadas como significativas, sendo elas: Porcentagem estequiométrica de Peróxido de Hidrogênio Linear - X1(L), Porcentagem estequiométrica de Peróxido de Hidrogênio Quadrática - X1(Q), Porcentagem estequiométrica de Água Linear - X2(L), Faixa de Temperatura do 
processo Linear - X3(L) e Faixa de Temperatura do processo Quadrática - X3(L) Porcentagem estequiométrica de Água Linear*Faixa de temperatura do processo Linear - X2X3.

Tabela 16 - Coeficientes de Regressão.

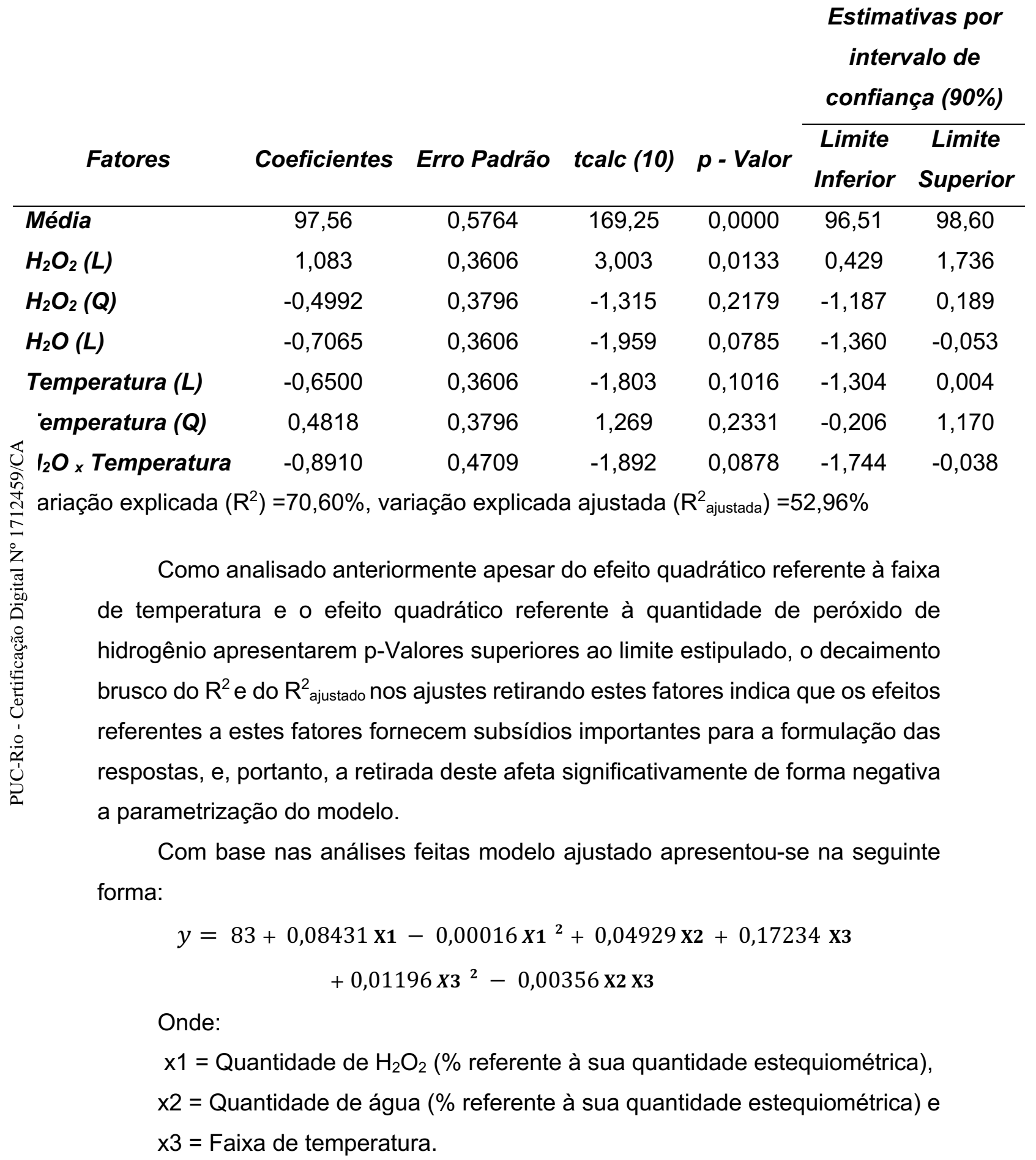

Com o nível de significância igual a $\alpha=10 \%$, como anteriormente já especificado, temos que o valor de $F_{\text {tab }}=F_{(6 ; 10 ; 10 \%)}=2,46$, onde 6 é equivalente 
aos graus de liberdade da regressão e 10 equivalente aos graus de liberdade dos resíduos. $\mathrm{O}$ teste $\mathrm{F}$ indica que o modelo possui capacidade preditiva quando $F_{\text {calc }} \geq F_{\text {tab. }}$

A Tabela 17 abaixo apresenta os dados obtidos pelo cálculo da ANOVA.

Tabela 17 - ANOVA.

\begin{tabular}{l|ccccc}
$\begin{array}{l}\text { Fonte de } \\
\text { variação }\end{array}$ & $\begin{array}{c}\text { Soma dos } \\
\text { quadrados }\end{array}$ & $\begin{array}{c}\text { Graus de } \\
\text { liberdade }\end{array}$ & $\begin{array}{c}\text { Quadrado } \\
\text { médio }\end{array}$ & $F_{\text {calc }}$ & $p$-Valor \\
\hline $\begin{array}{l}\text { Regressão } \\
\text { Resíduos }\end{array}$ & 45,19 & 6 & 8,752 & & \\
Res,14 & 10 & 1,569 & 5,0 & 0,000557 \\
Total & 60,33 & 16 & & & \\
$\left(R^{2}\right)=70,60 \%$ & $F_{(6 ; 10 ; 10 \%)}=2,46$ & & &
\end{tabular}

Observa-se a partir da Tabela 17 que o valor de $\mathrm{F}_{\text {calc }}=5,0$ para o modelo é maior que o $\mathrm{F}_{\operatorname{tab}(6 ; 10 ; 10 \%)}=2,46$, e p-Valor $(0,000557)$ abaixo do nível de significância estipulado para o presente estudo. Desta forma, pode-se afirmar que o modelo possui um bom ajuste aos resultados e, portanto, satisfaz os requisitos para a construção das superfícies de resposta e curvas de níveis.

Em seguida, para uma análise qualitativa, foi posto em gráficos os valores observados vs. valores preditos referente, obtido pelo software Statistica na Figura 11. 


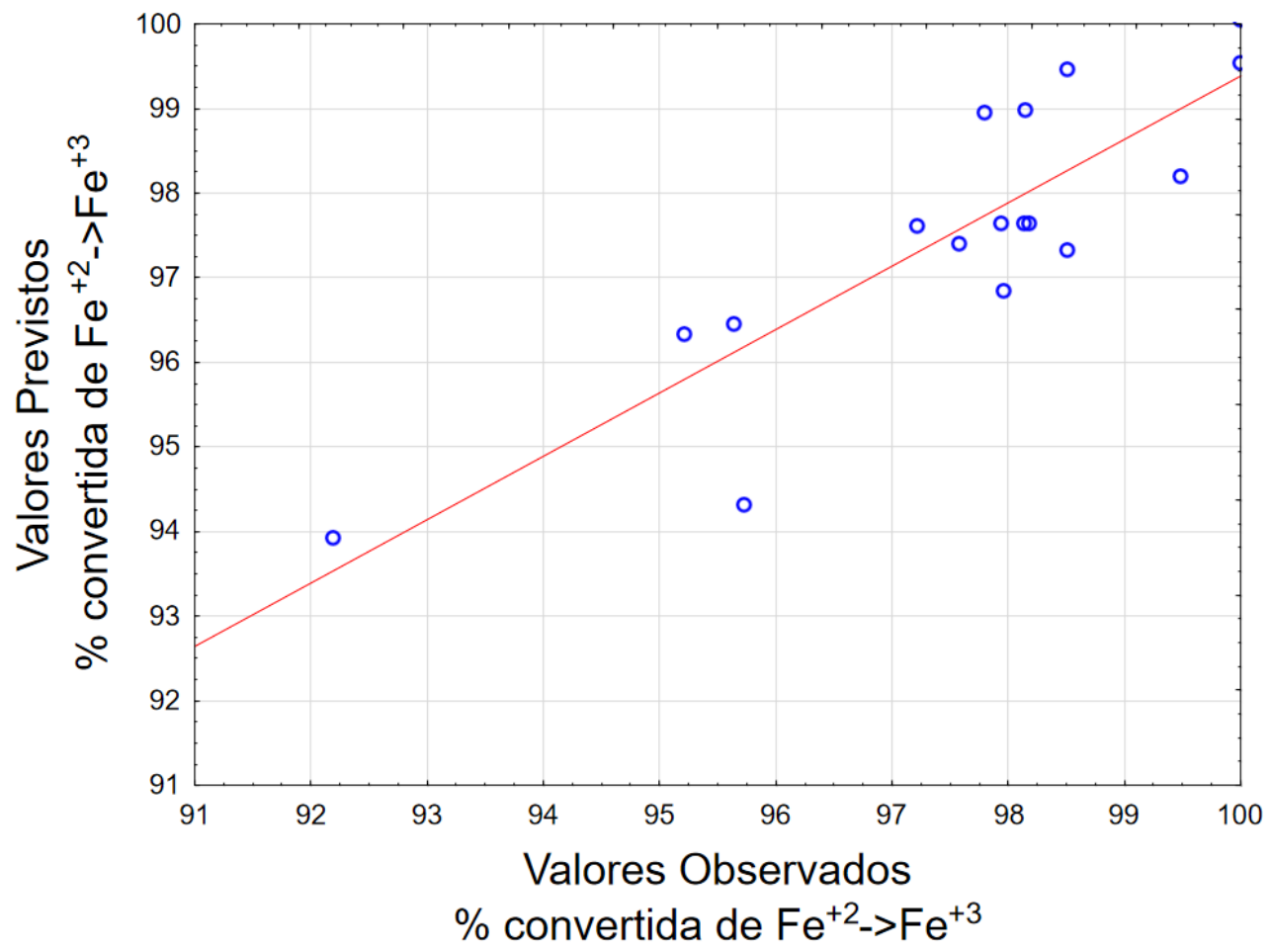

Figura 11 - Valores observados versus valores previsto da conversão de $\mathrm{Fe}^{2+} \mathrm{em} \mathrm{Fe}^{3+}$ obtido pelo software Statistica.

A Figura 11 descreve os valores observados experimentalmente versus os valores previstos pelo modelo associado a resposta de conversão de $\mathrm{Fe}^{2+} \mathrm{em} \mathrm{Fe}^{3+}$. Como esperado, devido a porcentagem de variação explicada não se apresentar

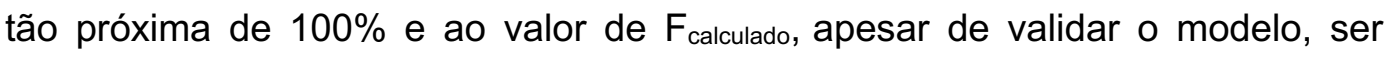
próximo do valor limite ( $\left.F_{\text {tabelado }}\right)$ indicando não ser altamente significativo, observase uma discordância entre os valores observados e do modelo parametrizado.

A descrição gráfica do modelo ajustado obtido através da superfície de resposta exibe a projeção de seus cortes sobre o plano dos fatores, gerando as curvas de contorno e simplificando a interpretação dos resultados para identificar a região de operação ótima, a ser especificada. Tais perfis de respostas tiveram para as variáveis fixas os valores dos seus respectivos pontos centrais. Estes perfis são exibidos pela Figura 12, Figura 13 e Figura 14. 

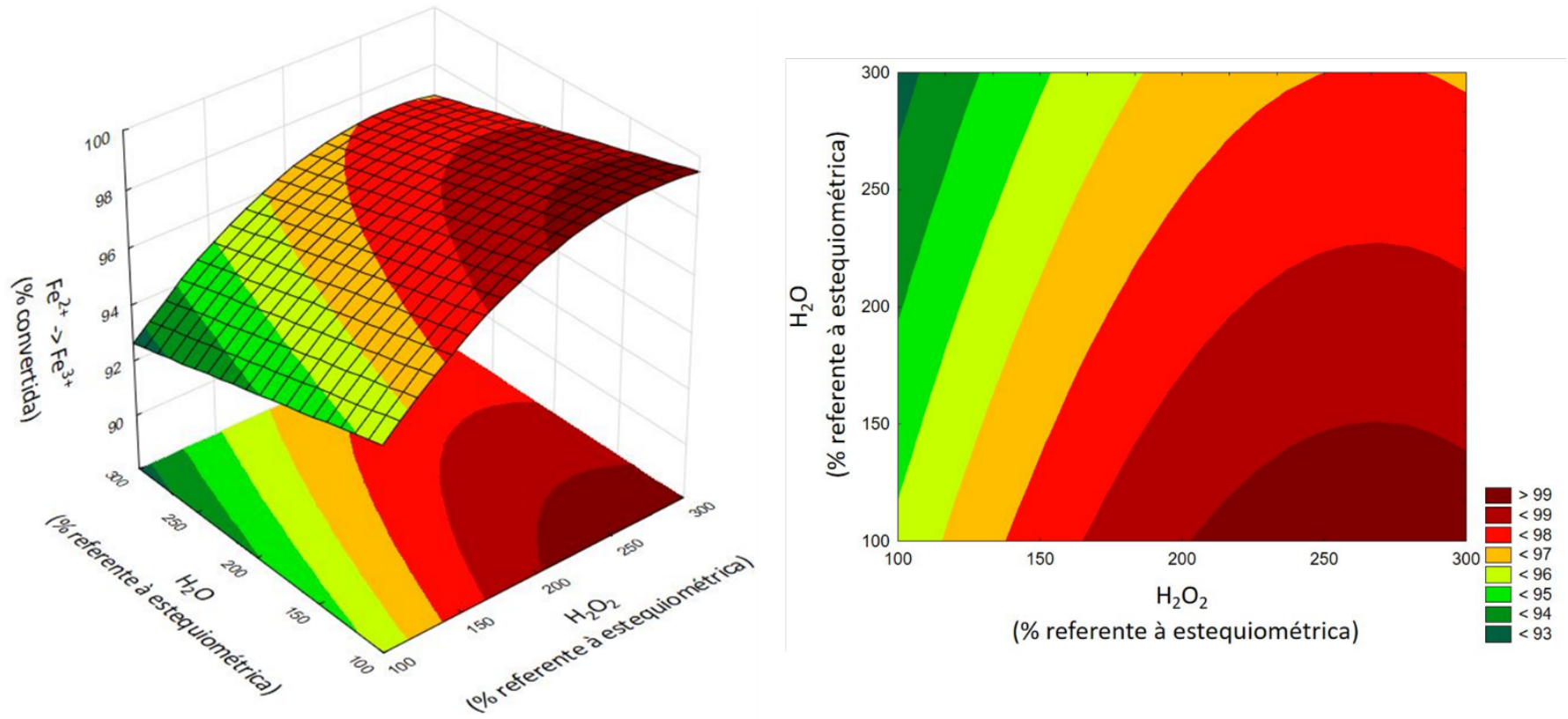

Figura 12 - Superfície de resposta e curvas de contorno para o parâmetro conversão de $\mathrm{Fe}^{+2}$ em $\mathrm{Fe}^{+3}$ em função ( đadição de peróxido de hidrogênio e água ao processo, na temperatura operacional igual a $17,5^{\circ} \mathrm{C}$.
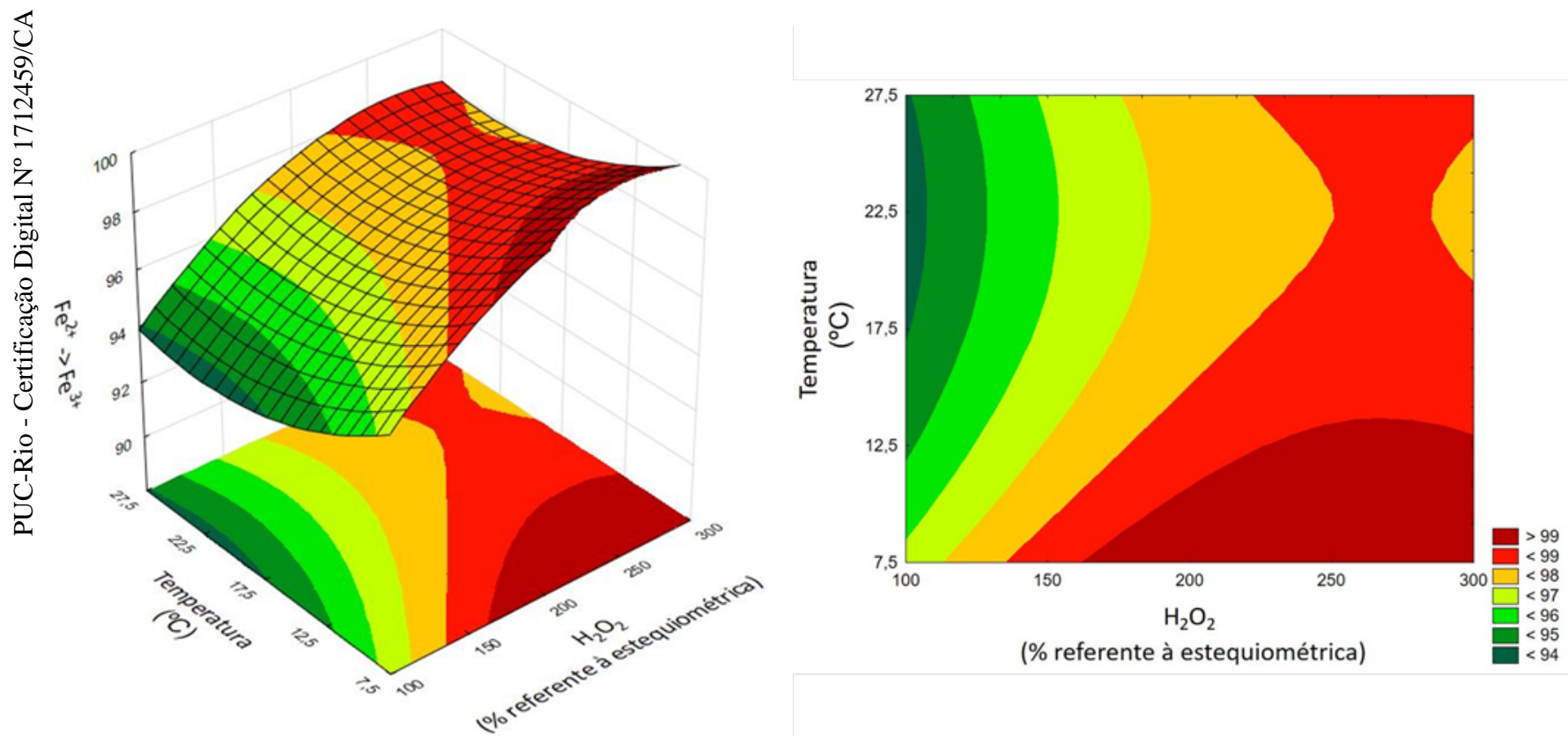

Figura 13 - Superfície de resposta e curvas de contorno para o parâmetro conversão de $\mathrm{Fe}^{+2}$ em $\mathrm{Fe}^{+3}$ em função da adição de peróxido de hidrogênio e faixa de temperatura operacional, com adição de $200 \%$ do valor estequiométrico de água ao processo. 

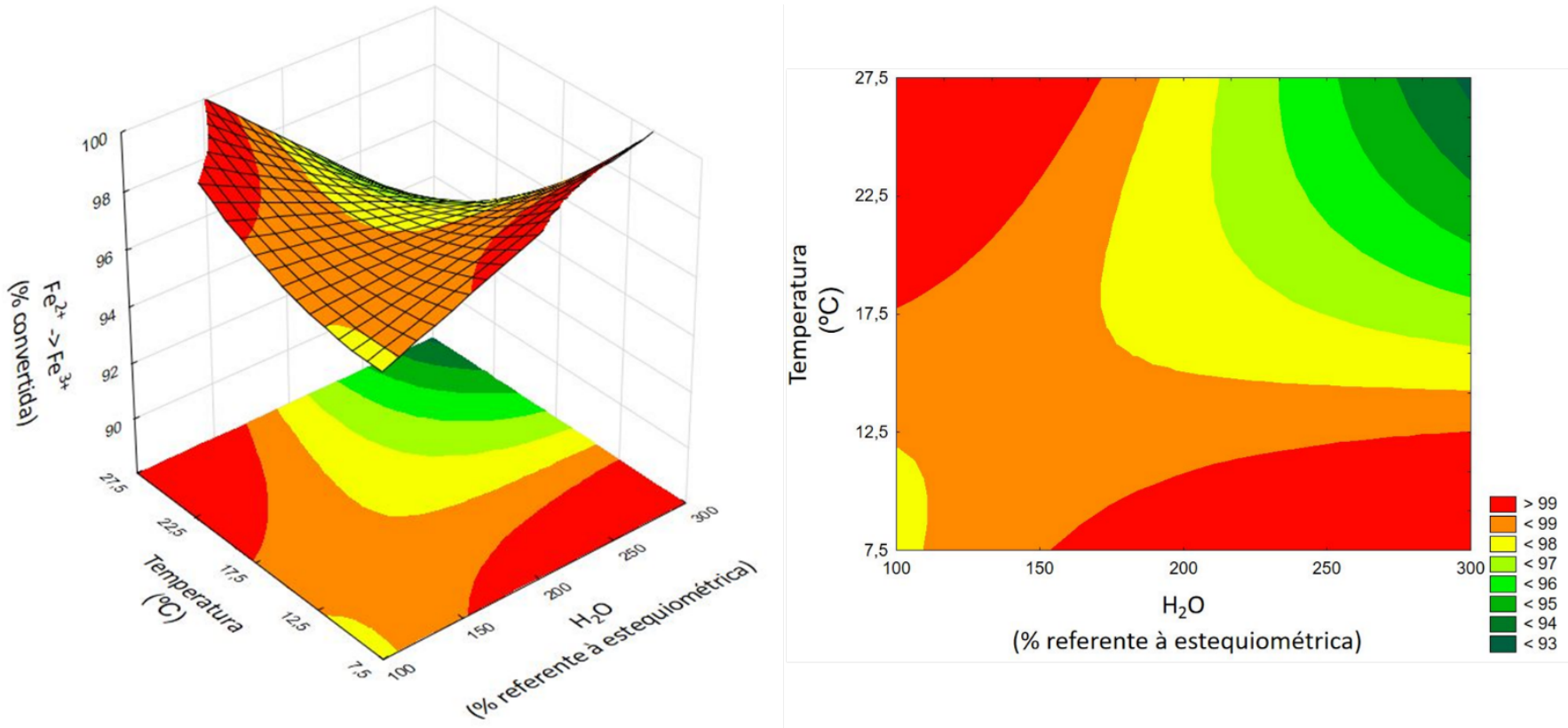

Figura 14 - Superfície de resposta e curvas de contorno para o parâmetro conversão de $\mathrm{Fe}^{+2}$ em $\mathrm{Fe}^{+3}$ em função da faixa de temperatura operacional e da adição de água ao processo, com adição de $200 \%$ do valor estequiométrico de peróxido de hidrogênio ao processo.

Para a etapa de determinação do ponto ótimo de operação e em seguida a etapa de validação experimental foi necessário determinar quais as condições operacionais do processo que resultariam em um produto final dentro das condições satisfatórias para um coagulante férrico comercial. As condições operacionais utilizadas como parâmetro foram:

I. Concentração de ferro férrico solúvel em água $\left(\mathrm{Fe}^{3+}\right)$ maior ou igual a $9,0 \%$.

II. Concentração de ferro ferroso solúvel em água $\left(\mathrm{Fe}^{2+}\right)$ menor que 1,5 $\%$, com base em $9,0 \%$ de ferro férrico.

III. Produto final apresentando estabilidade a longo prazo, isto é, não apresentando sinais de formação de produto sedimentado.

A estabilidade do produto final dos ensaios foi analisada após aproximadamente 2 meses a partir da data da sua confecção e as imagens das soluções finais encontram-se no Anexo 9.3.

A Tabela 18 apresenta os percentuais mássicos de $\mathrm{Fe}^{2+}$ e $\mathrm{Fe}^{3+}$ e as respostas das análises de estabilidade das amostras de cada ensaios. 
Tabela 18 - Percentuais mássicos de $\mathrm{Fe}^{2+}$ e $\mathrm{Fe}^{3+}$ e a análise de estabilidade dos coagulantes férricos produzidos em cada ensaio

\begin{tabular}{|c|c|c|c|c|c|c|c|}
\hline \multicolumn{3}{|c|}{ Amostras } & \multicolumn{2}{|c|}{$\mathrm{Fe}^{3+}$} & \multicolumn{3}{|c|}{$\mathrm{Fe}^{2+}$} \\
\hline Ensaio & $\begin{array}{c}\text { Densidade } \\
(\mathrm{g} / \mathrm{L})\end{array}$ & Estabilidade & $\begin{array}{l}{\left[\mathrm{Fe}^{3+}\right]} \\
(\mathrm{g} / \mathrm{L})\end{array}$ & $\begin{array}{l}\text { \% mássico } \\
\text { na amostra }\end{array}$ & $\begin{array}{c}\text { \% mássico } \\
\text { limite }\end{array}$ & $\begin{array}{l}{\left[\mathrm{Fe}^{2+}\right]} \\
(\mathrm{g} / \mathrm{L})\end{array}$ & $\begin{array}{l}\% \text { mássico } \\
\text { na amostra }\end{array}$ \\
\hline 1 & 1418,1 & estável & 156,65 & 11,05 & 1,84 & 11,08 & 0,78 \\
\hline 2 & 1393,3 & estável & 164,63 & 11,82 & 1,97 & 3,10 & 0,22 \\
\hline 3 & 1325,4 & estável & 164,00 & 12,37 & 2,06 & 3,56 & 0,27 \\
\hline 4 & 1322,2 & estável & 165,22 & 12,50 & 2,08 & 2,50 & 0,19 \\
\hline 5 & 1439,3 & estável & 156,65 & 10,88 & 1,81 & 11,09 & 0,77 \\
\hline 6 & 1412,1 & estável & 167,74 & 11,88 & 1,98 & 0,00 & 0,00 \\
\hline 7 & 1343,3 & estável & 154,84 & 11,53 & 1,92 & 12,80 & 0,95 \\
\hline 8 & 1323,3 & estável & 160,29 & 12,11 & 2,02 & 7,31 & 0,55 \\
\hline 9 & 1333,0 & estável & 154,77 & 11,61 & 1,94 & 13,11 & 0,98 \\
\hline 10 & 1350,4 & estável & 167,02 & 12,37 & 2,06 & 0,86 & 0,06 \\
\hline 11 & 1468,7 & estável & 163,43 & 11,13 & 1,85 & 4,34 & 0,30 \\
\hline 12 & 1301,6 & estável & 159,81 & 12,28 & 2,05 & 8,03 & 0,62 \\
\hline 13 & 1374,2 & estável & 166,53 & 12,12 & 2,02 & 0,00 & 0,00 \\
\hline 14 & 1377,5 & estável & 165,80 & 12,04 & 2,01 & 2,34 & 0,17 \\
\hline 15 & 1369,7 & estável & 164,65 & 12,02 & 2,00 & 3,13 & 0,23 \\
\hline 16 & 1368,5 & estável & 165,03 & 12,06 & 2,01 & 3,06 & 0,22 \\
\hline 17 & 1377,6 & estável & 164,47 & 11,94 & 1,99 & 3,45 & 0,25 \\
\hline
\end{tabular}

Pela Tabela 18, observa-se que todas as amostras atingiram tanto a estabilidade necessária quanto os percentuais mássicos de ferro ferroso e férrico requeridos.

Para a determinação das condições do processo a serem utilizadas na validação experimental, a partir dos dados da Tabela 18 calculou-se a conversão mínima necessária para cada condição de processo realizado, exibida na Tabela 19. 
Tabela 19 - Conversão mínima requerida para cada ensaio

\begin{tabular}{|c|c|}
\hline Ensaio & $\begin{array}{c}\text { \% de conversão mínima } \\
\text { de } \\
\mathrm{Fe}^{2+} \rightarrow \mathrm{Fe}^{3+}\end{array}$ \\
\hline 1 & 84,43 \\
\hline 2 & 83,64 \\
\hline 3 & 83,70 \\
\hline 4 & 83,58 \\
\hline 5 & 84,44 \\
\hline 6 & 83,33 \\
\hline 7 & 84,61 \\
\hline 8 & 84,06 \\
\hline 9 & 84,63 \\
\hline 10 & 83,42 \\
\hline 11 & 83,76 \\
\hline 12 & 84,13 \\
\hline 13 & 83,49 \\
\hline 14 & 83,57 \\
\hline 15 & 83,65 \\
\hline 16 & 83,62 \\
\hline 17 & 83,67 \\
\hline
\end{tabular}

Através da análise dos resultados, é possível observar que em média demanda-se uma conversão mínima de $83,84 \%$ do ferro ferroso presente em solução. Desta forma, torna-se necessário ao realizar a análise de superfície de resposta, identificar áreas que apresentem uma conversão de ferro ferroso em férrico, superior a $83,84 \%$.

Analisando a superfície de resposta, Figura 12, Figura 13 e Figura 14, observa-se que em todas as condições experimentais impostas para o processo estudado obteve-se conversões acima do limite necessário, com mínimo de conversão aproximado de 92\%. Logo, objetivou-se a determinação das condições de processo em que se obtêm simultaneamente a uma elevada conversão as melhores condições operacionais e de custo, portanto a minimização da quantidade adicionada de peróxido de hidrogênio (reagente de maior custo), controle de temperatura de operação com menor demanda de energia e condições operacionais que demandam menor tempo e maior segurança. 
A condição operacional escolhida é apresentada na Tabela 20.

Tabela 20 - Condições operacionais utilizadas no ensaio experimental para validação do modelo

\begin{tabular}{c|cc}
\multicolumn{1}{c}{ Variável } & $\begin{array}{c}\text { Condição } \\
\text { experimental }\end{array}$ & $\begin{array}{c}\text { Valor } \\
\text { codificado }\end{array}$ \\
\hline \% estequiométrica $\mathrm{H}_{2} \mathrm{O}_{2}$ & $150 \%$ & -1 \\
\% estequiométrica $\mathrm{H}_{2} \mathrm{O}$ & $200 \%$ & 0 \\
Temperatura & $17,5^{\circ} \mathrm{C}$ & 0
\end{tabular}

A Tabela 21 exibe o resultado predito pelo modelo matemático e a média dos resultados observados obtido pelo ensaio de validação experimental, efetuado em triplicata.

Tabela 21 - Resultados preditos e observados obtidos nas condições otimizadas do processo e erro percentual

$\begin{array}{cccc}\text { Variável resposta } & \begin{array}{c}\text { Resultado } \\ \text { predito }\end{array} & \begin{array}{c}\text { Resultado } \\ \text { experimental }\end{array} & \begin{array}{c}\text { Erro } \\ \text { percentual }\end{array} \\ \% \text { convertida } \mathrm{Fe}^{2+} \rightarrow \mathrm{Fe}^{3+} & 96,13 \% & 96,17 \% & 0,043 \%\end{array}$

A pequena diferença observada entre o resultado experimental e valor predito pelo modelo parametrizado, assegura que é possível considerar a nova metodologia para a obtenção do sulfato férrico, já que o resultado obtido no ensaio de validação foi satisfatório. Portanto, pode-se afirmar que, apesar do baixo coeficiente de explicação $\left(R^{2}\right)$ o planejamento fatorial promoveu a realização de condições experimentais onde foi possível otimizar a resposta do processo estudado, estabelecendo condições que garantiram as condições desejadas ao produto final.

\subsection{1. \\ Discussão físico-química das superfícies de resposta e curvas de contorno}

Através da análise das superfícies de resposta e curvas de contorno buscouse entender o comportamento das variáveis dentro das condições do processo estudado. 
- Quantidade de peróxido de hidrogênio versus quantidade de água em temperatura fixa de $17,5^{\circ} \mathrm{C}$.

A Figura 12 ilustra a superfície de resposta e curvas de contorno para o parâmetro conversão de $\mathrm{Fe}^{2+}$ em $\mathrm{Fe}^{3+}$ em função da adição de peróxido de hidrogênio e água ao processo e possui como valor fixo a temperatura de operação em $17,5^{\circ} \mathrm{C}$.

Nestas condições operacionais observa-se que quanto maior o excesso de água menor será o efeito da oxidação do peróxido de hidrogênio, mesmo na condição onde ocorre adições de grandes quantidades do agente oxidante. Este fenômeno pode ser explicado devido ao fato de que quanto mais diluído o meio menor é a probabilidade de colisão entre as espécies $\mathrm{Fe}^{2+}$ e $\mathrm{o}_{2} \mathrm{O}_{2}$, aumentando a probabilidade de que parte do peróxido de hidrogênio em solução entre em decomposição e não contribua para a conversão.

- Quantidade de peroxido de hidrogênio versus temperatura em quantidade de água fixa em $200 \%$ da sua quantidade estequiométrica.

A Figura 13 ilustra a superfície de resposta e curvas de contorno para o parâmetro conversão de $\mathrm{Fe}^{2+}$ em $\mathrm{Fe}^{3+}$ em função da adição de peróxido de hidrogênio e faixa de temperatura operacional, operando em adições de água em quantidade equivalente a $200 \%$ do seu valor estequiométrico.

Ao analisarmos o comportamento das variáveis, observa-se que é possível obter maiores conversões com a adição de menores quantidades de peróxido de hidrogênio ao operar em faixas de temperatura mais baixas. Nota-se que o aumento da temperatura até $22,5{ }^{\circ} \mathrm{C}$, nesta condição de diluição, reduz o percentual de $\mathrm{Fe}^{2+}$ convertido independentemente da adição de excesso de agente oxidante. Portanto, para menores adições de oxidante, nesta condição operacional de diluição, torna-se necessário um maior controle da temperatura.

Este comportamento pode ser explicado pela maior estabilidade do peróxido de hidrogênio em solução devido à baixa temperatura, isto é, este reagente oxidante não tem a sua auto decomposição incitada pela temperatura e, portanto, possui maior disponibilidade para atuar na conversão do $\mathrm{Fe}^{2+}$ em $\mathrm{Fe}^{3+}$.

Em ambos as figuras Figura 12 e Figura 13 é possível identificar um comportamento similar de queda da capacidade de conversão em operações com adição de grandes quantidades deste agente oxidante. Percebe-se que a adição de $\mathrm{H}_{2} \mathrm{O}_{2}$ é benéfica até aproximadamente adições com $270 \%$ da sua quantidade 
estequiométrica, já em quantidades maiores que esta observa-se uma queda na capacidade de conversão de $\mathrm{Fe}^{2+}$ em $\mathrm{Fe}^{3+}$. O comportamento destas superfícies de resposta indica que em baixas temperaturas há uma menor taxa de auto decomposição do peróxido de hidrogênio, conservando em solução grande parte do reagente que não entrou no processo de oxidação ou em decomposição. Operações em baixas temperaturas com adição de grandes quantidades de agente oxidante, geram um cenário de grande excesso de peróxido de hidrogênio em meio reacional em conjunto uma maior presença de $\mathrm{Fe}^{3+}$ de que $\mathrm{Fe}^{2+}$, visto que grande parte deste ferro (II) já havia sido convertido nas primeiras quantidades adicionadas de peróxido de hidrogênio. Este conjunto de fatores favorece a formação de $\mathrm{Fe}^{2+}$, como demonstrado pelas equações número 11 e 13.

Experimentalmente pode-se observar o fenômeno da conservação do peróxido de hidrogênio, quando operando em baixas temperaturas, ao visualizar a liberação gradual e lenta de oxigênio por todo o meio reacional com adição do agente oxidante abaixo da quantidade estequiométrica e, portanto, indicando que a reação paralela de decomposição havia sido desacelerada.

Também é possível observar na Figura 13 que acima de $23^{\circ} \mathrm{C}$ ocorre um aumento do percentual de $\mathrm{Fe}^{2+}$ convertido a partir da adição de $250 \%$ da quantidade estequiométrica de peróxido de hidrogênio. Este aumento da conversão indica que acima desta temperatura grande parte do peróxido de hidrogênio que não reagiu com $\mathrm{Fe}^{2+}$ se decompôs e, portanto, não se proporcionou um grande excesso de agente oxidante presente no meio reacional que induziria a conversão de $\mathrm{Fe}^{3+} \mathrm{em} \mathrm{Fe}^{2+}$.

Experimentalmente nos ensaios de $22,5^{\circ} \mathrm{C}$ e $27,5^{\circ} \mathrm{C}$, pode-se observar a decomposição do peróxido de hidrogênio assim que este entrava em contato com a superfície do meio reacional e identificou-se a presença de oxigênio gasoso sendo liberado no seio da solução apenas em situações acima de $200 \%$ da quantidade estequiométrica do agente oxidante.

- Quantidade de água versus temperatura em quantidade de peróxido de hidrogênio fixa em $200 \%$ da quantidade estequiométrica.

A Figura 14, que ilustra a superfície de resposta e curvas de contorno para o parâmetro conversão de $\mathrm{Fe}^{2+}$ em $\mathrm{Fe}^{3+}$ em função da faixa de temperatura operacional e da adição de água ao processo, exibe a relação entre a quantidade de água e a temperatura. 
Observa-se que operando em adições de peróxido de hidrogênio 200\% do seu valor estequiométrico, é possível atingir maiores taxas de conversão na faixa de temperatura entre $7,5^{\circ} \mathrm{C}$ e $12,5^{\circ} \mathrm{C}$ e em adição entre $155 \%$ e $300 \%$ da quantidade estequiométrica de água. Podemos deduzir que na faixa de temperatura entre $7,5^{\circ} \mathrm{C}$ e $12,5^{\circ} \mathrm{C}$ a auto decomposição do peróxido de hidrogênio é inibida e apesar de encontrar-se em um ambiente diluído a sua conservação em solução pela temperatura propicia a atuação deste reagente como oxidante.

Uma outra faixa de operação com altos índices de conversão para a mesma quantidade de peróxido de hidrogênio adicionada, na Figura 14, ocorre entre 17,6 ${ }^{\circ} \mathrm{C}$ e $27,5^{\circ} \mathrm{C}$ e em adição entre $100 \%$ e $170 \%$ do valor estequiométrico de água. Por se tratar de uma operação na qual há uma grande quantidade de peróxido de hidrogênio adicionada, podemos concluir que grande parte se decompõe em água e oxigênio durante a adição, como pode ser observado visualmente durante os experimentos, desta forma impedindo um excesso deste reagente em solução iniciasse a reação de Fenton-like, demonstrada nas equações 11 e 13, e a condição de baixa diluição propicia um maior contato direto entre o reagente oxidante e o $\mathrm{Fe}^{2+}$.

\section{3.}

\section{Análise da conversão de $\mathrm{Fe}^{2+}$ em $\mathrm{Fe}^{3+}$ em função da quantidade de peróxido de hidrogênio}

A Figura 15 apresenta a Conversão de $\mathrm{Fe}^{2+}$ em $\mathrm{Fe}^{3+}$ (\%) em função da adição de peróxido de hidrogênio. Os resultados permitiram avaliar qualitativamente a progressão do processo de oxidação nas diferentes condições experimentais. 


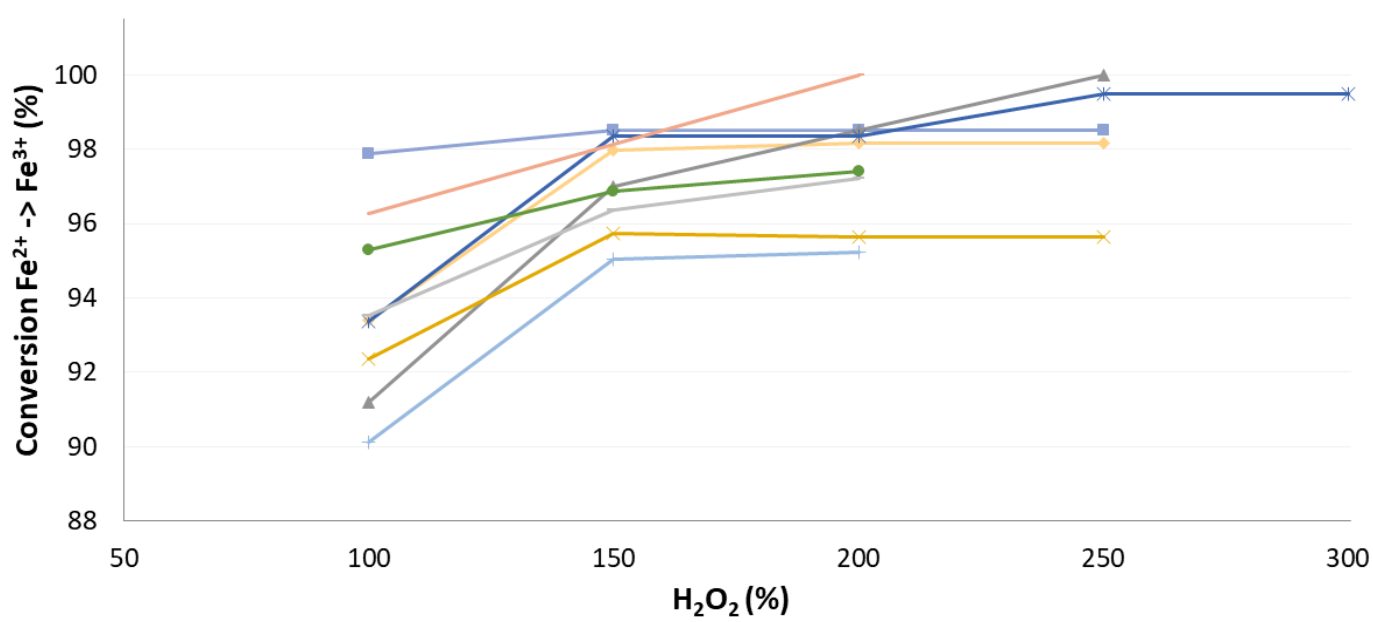

$\longrightarrow$ H2O: $150 \%$ Temperature: $12,50 \mathrm{C} \rightarrow-\mathrm{H} 2 \mathrm{O}: 250 \%$ Temperature: $12,5 \mathrm{oC} \longrightarrow \mathrm{H} 2 \mathrm{O}: 150 \%$ Temperature: $22,5 \mathrm{oC}$

$\longrightarrow$ H2O: $250 \%$ Temperature: $22,50 \mathrm{C} \rightarrow \mathrm{H} 2 \mathrm{O}: 200 \%$ Temperature: $17,5 \mathrm{oC} \rightarrow \mathrm{H} 2 \mathrm{O}: 100 \%$ Temperature: $17,5 \mathrm{oC}$

- H2O: $300 \%$ Temperature: $17,50 \mathrm{C} \longrightarrow \mathrm{H} 2 \mathrm{O}: 200 \%$ Temperature: $7,5 \mathrm{oC}-\mathrm{H} 2 \mathrm{O}: 200 \%$ Temperature: $27,5 \mathrm{oC}$

Figura 15 - \% Convertida de $\mathrm{Fe}^{+2}$ em $\mathrm{Fe}^{+3}$ versus adição de peróxido de hidrogênio no meio

${ }^{*} \mathrm{H}_{2} \mathrm{O}_{2}$ e $\mathrm{H}_{2} \mathrm{O}$ em \% referentes às suas respectivas quantidades estequiométricas.

É possível notar que a adição de $100 \%$ da quantidade estequiométrica de $\mathrm{H}_{2} \mathrm{O}_{2}$ em todas as condições operacionais promoveu conversões acima de $90 \%$ de $\mathrm{Fe}^{2+}$ em $\mathrm{Fe}^{3+}$.

Durante a realização do procedimento experimental para a produção de sulfato férrico, encontrou-se uma maior dificuldade para o controle da temperatura durante as duas primeiras adições, isto é, $50 \%$ e $100 \%$ da quantidade estequiométrica de $\mathrm{H}_{2} \mathrm{O}_{2}$, indicando que grande parte do $\mathrm{Fe}^{2+}$ em solução estava sendo oxidado nestas etapas, observação a qual corrobora com os dados observados na Figura 15.

Em todos os ensaios, observa-se que a partir da adição de $100 \%$ da quantidade estequiométrica de $\mathrm{H}_{2} \mathrm{O}_{2}$ os resultados se tornam extremamente próximos pois em todos os casos foi possível obter grandes percentuais de conversão. Novamente, é possível observar que os arranjos de condições impostas aos experimentos não foram suficientes para a produzir mudanças significativas entre as respostas de conversão do $\mathrm{Fe}^{2+} \mathrm{em} \mathrm{Fe}^{3+}$ nos ensaios.

Pode-se inferir que, possivelmente, a adição de um grande excesso de peróxido de hidrogênio e a proximidade das faixas de temperatura estudadas em conjunto com a variabilidade da mesma, dentro da faixa, tenham causado a proximidade das respostas observadas, dificultando a análise para a determinação dos fatores que de fato influenciaram o processo de conversão. 
Através do desvio padrão médio das respostas de conversão, calculado como $1,23 \%$, foi feito a representação gráfica da variabilidade dos resultados obtidos.

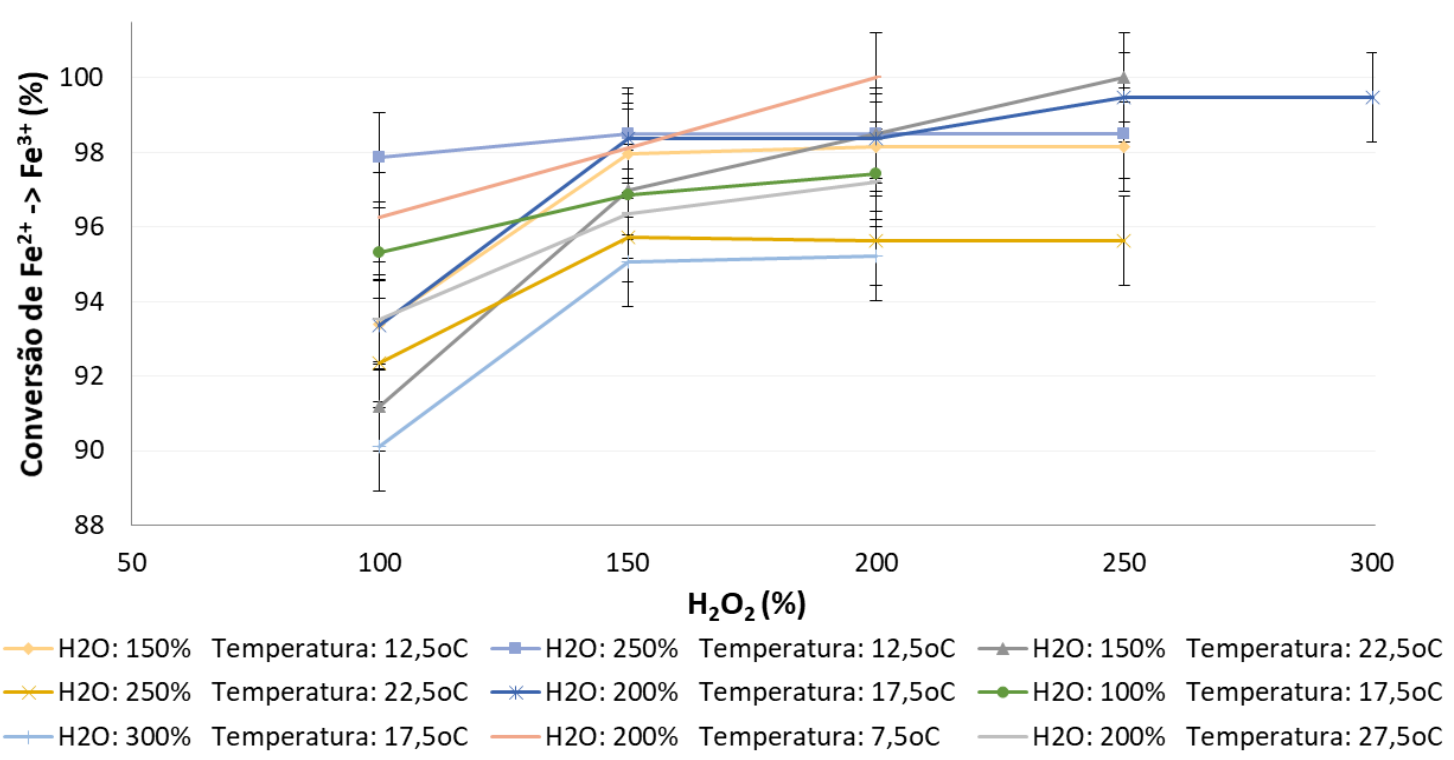

Figura 16 - Variabilidade da resposta de conversão

( $\left.{ }^{*}\right) \mathrm{H}_{2} \mathrm{O}_{2}$ e $\mathrm{H}_{2} \mathrm{O}$ em \% referentes às suas respectivas quantidades estequiométricas

Analisando a Figura 16 conclui-se que devido aos erros intrínsecos a técnica de experimentação e análise e, também, devido à grande proximidade das respostas obtidas, não é possível considerar que grande parte destas respostas se diferem.

Com base na Figura 16 e nas análises de resultados até o momento feitas, é possível deduzir que a técnica de experimentação em conjunto com a inviabilidade da estabilização da temperatura em um valor fixo durante o processo de oxidação e as diluições necessárias para a técnica de análise, possam ser os principais fatores que acarretaram na dificuldade encontrada durante a determinação dos efeitos significativos na análise estatística e o não tão alto $R^{2}$ obtido.

Vale frisar que apesar da possibilidade de a resposta variar em $+/-1,23 \%$, ainda assim todos os coagulantes obtidos apresentaram conversões acima de $88 \%$ e, portanto, contendo $\mathrm{Fe}^{3+}$ dentro do requerido comercialmente.

Com a finalidade de observar os diferentes perfis de conversão de $\mathrm{Fe}^{2+} \mathrm{em}$ $\mathrm{Fe}^{3+}$ em função da temperatura e da diluição, com todos os dados coletados durante a experimentação ao longo da adição de peróxido de hidrogênio, foram feitas as seguintes análises: análise do perfil de conversão pelos ensaios 
referentes aos pontos axiais das variáveis temperatura e água em conjunto com os pontos centrais e análises do perfil de conversão pelo agrupamento dos dados em mesma temperatura e em diferentes diluições e a análise do perfil de conversão pelo agrupamento dos dados em diluições iguais e em diferentes temperaturas . A Figura 17, a Figura 18, a Figura 19 e a Figura 20 exibem os conjuntos de gráficos.

- Análise da influência da temperatura no perfil de conversão de $\mathrm{Fe}^{2+}$ em $\mathrm{Fe}^{3+}$ na condição operacional de diluição equivalente a $200 \%$ da quantidade estequiométrica água.

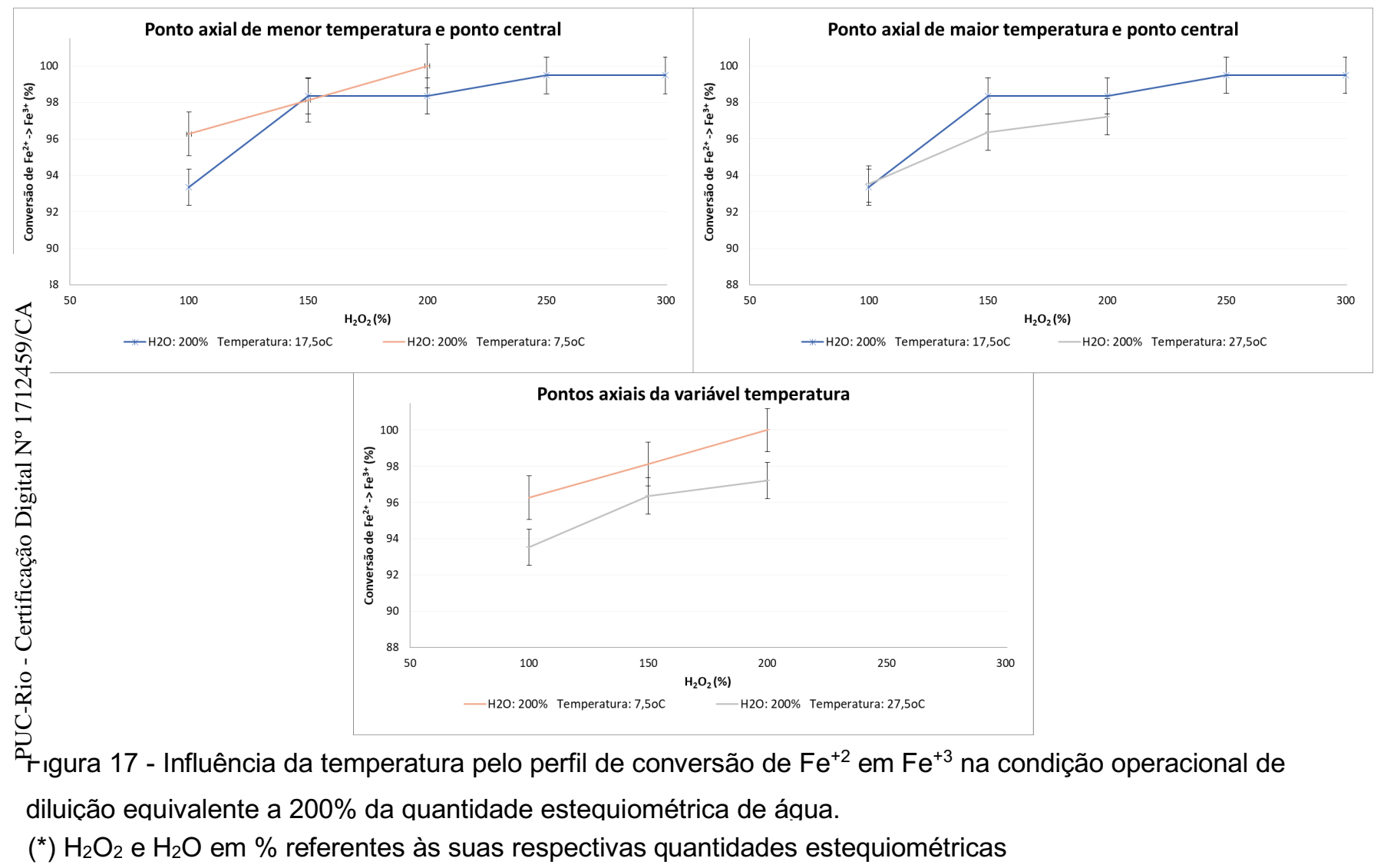

Analisando os gráficos contidos na Figura 17, em condição de diluição equivalente a água em $200 \%$ de sua quantidade estequiométrica, observa-se que com a quantidade estequiométrica de peróxido de hidrogênio adicionada na menor temperatura de operação $\left(7,5^{\circ} \mathrm{C}\right)$ promove-se uma maior conversão de $\mathrm{Fe}^{2+} \mathrm{em}$ $\mathrm{Fe}^{3+}$, comparado às conversões obtidas nas demais temperaturas.

$\mathrm{Na}$ condição de adição de $150 \%$ da quantidade estequiométrica de peróxido de hidrogênio, observa-se que não há uma diferença significativa na conversão de $\mathrm{Fe}^{2+}$ em $\mathrm{Fe}^{3+}$ entre as temperaturas de $7,5^{\circ} \mathrm{C}$ e $17,5^{\circ} \mathrm{C}$. Já a conversão de $\mathrm{Fe}^{2+}$ em $\mathrm{Fe}^{3+}$ obtida a $27,5{ }^{\circ} \mathrm{C}$, quando adicionado de $150 \%$ da quantidade 
estequiométrica de peróxido de hidrogênio, apresenta-se significativamente menor que as conversões $\mathrm{Fe}^{2+}$ em Fe ${ }^{3+}$ obtidas nas temperaturas de $7,5^{\circ} \mathrm{C}$ e 17,5 ${ }^{\circ} \mathrm{C}$.

A adição de $200 \%$ da quantidade estequiométrica de peróxido de hidrogênio demonstrou-se benéfica para o aumento da conversão a $7,5^{\circ} \mathrm{C}$. Já na temperatura de $17,5^{\circ} \mathrm{C}$ a conversão manteve-se estável, equivalendo-se ao resultado obtido a $27,5^{\circ} \mathrm{C}$.

Com base nas análises feitas acima, percebe-se que a baixa temperatura promove de fato a conservação do peróxido de hidrogênio em solução, devido à inibição de sua auto decomposição térmica, traduzido pelo beneficiamento da conversão nas menores temperaturas. Portanto, é possível promover conversões satisfatórias necessitando menores quantidades de peróxido de hidrogênio indicando um potencial ganho econômico. Também é possível inferir que a auto decomposição é inibida de forma parcial pela baixa temperatura, devido ao aumento da conversão pela adição de agente oxidante.

As análises para a quantificação do peróxido de hidrogênio residual identificaram que: a $7,5^{\circ} \mathrm{C}$ e adição de $200 \%$ da quantidade estequiométrica de peróxido de hidrogênio $3,07 \%$ de peróxido de hidrogênio não foram consumidos ao final da reação; a $17,5^{\circ} \mathrm{C}$ e adição de $250 \%$ da quantidade estequiométrica de peróxido de hidrogênio $3,16 \%$ do peróxido de hidrogênio adicionado não reagiu e manteve-se na solução; e a $27,5{ }^{\circ} \mathrm{C}$ e adição de $200 \%$ da quantidade estequiométrica de peróxido de hidrogênio não foi identificado peróxido de hidrogênio residual ao fim da reação. Portanto como visto nas análises, foi possível através da inibição da auto decomposição do peróxido de hidrogênio atingir maiores conversões de $\mathrm{Fe}^{2+}$ em $\mathrm{Fe}^{3+}$ com uma menor quantidade de peróxido de hidrogênio adicionada. 
- Análise da influência da diluição no perfil de conversão de $\mathrm{Fe}^{2+}$ em $\mathrm{Fe}^{3+}$ na condição operacional de temperatura equivalente a $17,5^{\circ} \mathrm{C}$.
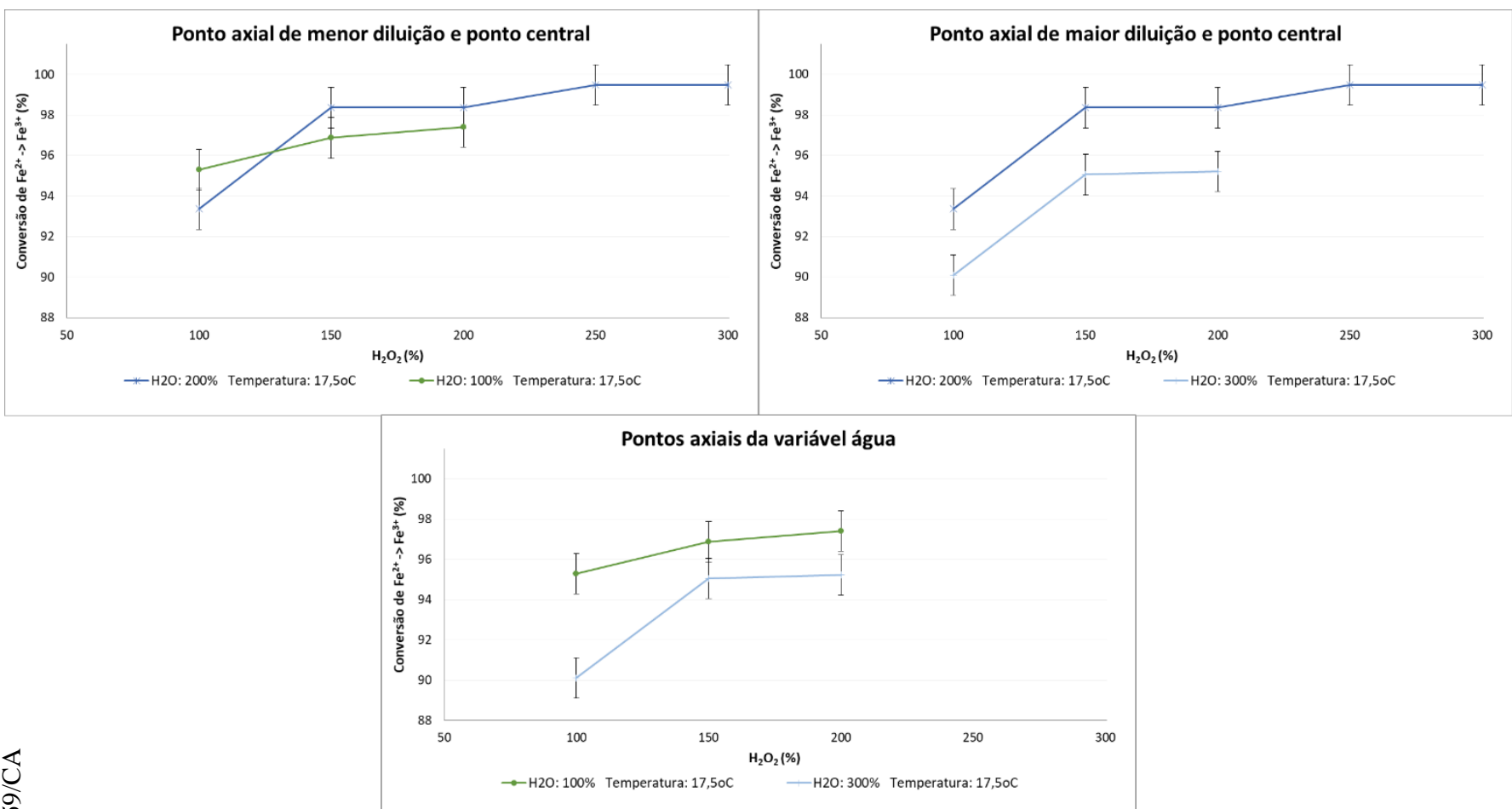

=igura 18 - Influência da diluição no perfil de conversão de $\mathrm{Fe}^{+2}$ em Fe $\mathrm{Fe}^{+3}$ na condição operacional de emperatura equivalente a $17,5^{\circ} \mathrm{C}$

*) $\mathrm{H}_{2} \mathrm{O}_{2}$ e $\mathrm{H}_{2} \mathrm{O}$ em \% referentes às suas respectivas quantidades estequiométricas

Analisando os gráficos contidos na Figura 18, observa-se que com a quantidade estequiométrica de peróxido hidrogênio adicionada a menor condição de diluição, equivalente à quantidade estequiométrica de água adicionada ao sistema, promoveu uma maior conversão de $\mathrm{Fe}^{2+}$ em $\mathrm{Fe}^{3+}$, comparada as conversões obtidas nas condições de adição de maiores diluições.

Na condição de adição de $150 \%$ da quantidade estequiométrica de peróxido de hidrogênio, observa-se que não há uma diferença significativa na conversão de $\mathrm{Fe}^{2+}$ em $\mathrm{Fe}^{3+}$ entre as diluições contendo a quantidade estequiométrica e $200 \%$ da quantidade estequiométrica de água, diferindo da baixa conversão obtida com $300 \%$ da quantidade estequiométrica de água.

A adição de $200 \%$ da quantidade estequiométrica de peróxido de hidrogênio não se demonstrou altamente benéfica para nenhuma das condições de diluição, gerando um leve crescimento apenas na condição onde havia a quantidade estequiométrica de água.

O conjunto das análises feitas acima indicam que as condições de operação em temperatura de $17,5{ }^{\circ} \mathrm{C}$ e diluição na condição estequiométrica são 
suficientemente capazes de promover altas conversões, levando a suposição que nestas condições há a promoção da inibição da auto decomposição térmica.

A diluição com $200 \%$ da quantidade estequiométrica de água não demonstrou contribuir significativamente para o processo. A diluição com 300\% da quantidade estequiométrica de água demonstrou ser prejudicial para o processo, indicando que a temperatura de $17,5^{\circ} \mathrm{C}$, como visto na análise anterior, não promove a total inibição da auto decomposição térmica e sim parcial. A baixa conversão na mais alta diluição também indicou que a água atua como dispersor tanto da temperatura quanto da matéria. O meio reacional altamente diluído dificulta o encontro do ferro com o peróxido de hidrogênio, aumentando a probabilidade de auto decomposição do mesmo.

As análises para a quantificação do peróxido de hidrogênio residual identificaram que: com a quantidade estequiométrica de água e adição de $200 \%$ da quantidade estequiométrica de peróxido de hidrogênio 0,07\% de peróxido de hidrogênio não foram consumidos ao final da reação; com a adição de $200 \%$ da quantidade estequiométrica de água e adição de $300 \%$ da quantidade estequiométrica de peróxido de hidrogênio $3,16 \%$ do peróxido de hidrogênio adicionado não foram consumidos ao final da reação; e com a adição de $300 \%$ da quantidade estequiométrica de água e $200 \%$ da quantidade estequiométrica de peróxido de hidrogênio não foi identificado peróxido de hidrogênio residual ao fim da reação. Portanto como visto nas análises, o grande excesso de água não foi benéfico para a inibição da auto decomposição do peróxido de hidrogênio nesta temperatura.

- Análise da influência da diluição e da temperatura na conversão $\mathrm{Fe}^{2+} \mathrm{em}$ $\mathrm{Fe}^{3+}$
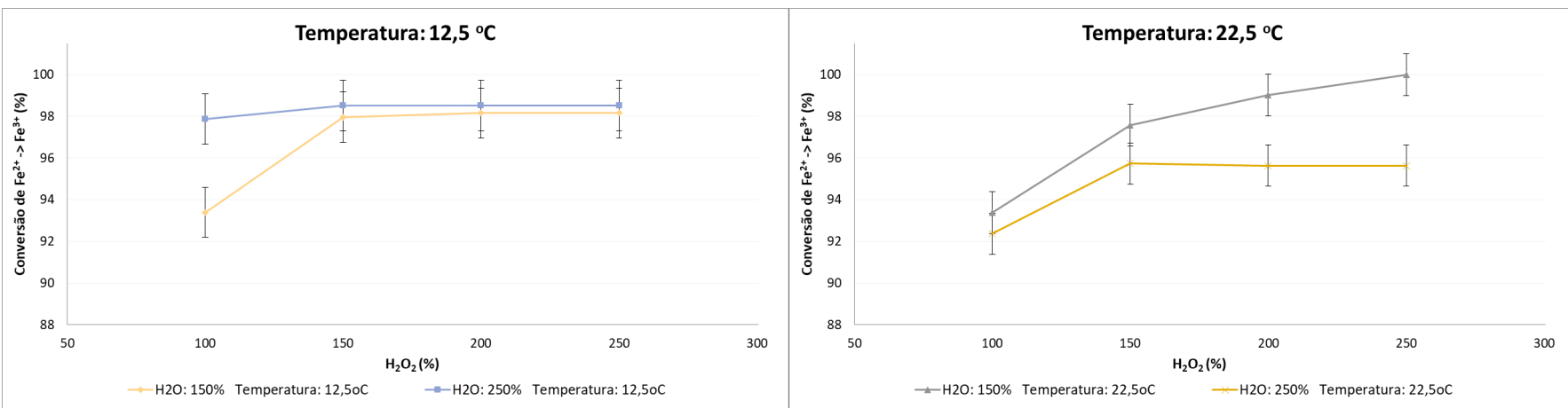

Figura 19 - Perfil de conversão de $\mathrm{Fe}^{+2}$ em Fe ${ }^{+3}$ na condição operacional em igual temperatura $\left(12,5^{\circ} \mathrm{C}\right.$ e $\left.22,5^{\circ} \mathrm{C}\right)$ e em diferentes diluições ( $150 \%$ e $250 \%$ de água)

${ }^{*}{ }^{*} \mathrm{H}_{2} \mathrm{O}_{2}$ e $\mathrm{H}_{2} \mathrm{O}$ em \% referentes às suas respectivas quantidades estequiométricas 
Analisando os gráficos contidos na Figura 19, observa-se que o comportamento de conversão na condição operacional de temperatura igual a $12,5^{\circ} \mathrm{C}$ é o oposto do comportamento obtido a $22,5^{\circ} \mathrm{C}$.

$\mathrm{Na}$ condição operacional de temperatura igual a $12,5^{\circ} \mathrm{C}$, observa-se que com a quantidade estequiométrica de peróxido de hidrogênio adicionada na condição de diluição igual a $250 \%$ da quantidade estequiométrica de água, promoveu-se uma maior conversão de $\mathrm{Fe}^{2+}$ em $\mathrm{Fe}^{3+}$ comparada a conversões obtida na condição com $150 \%$ da quantidade estequiométrica de água. Nas adições seguintes de excesso de peróxido de hidrogênio, observa-se que os percentuais convertidos de $\mathrm{Fe}^{2+}$ em $\mathrm{Fe}^{3+}$ tornam-se equivalentes. A análises para a quantificação do peróxido de hidrogênio identificaram que quando a diluição ocorreu com $250 \%$ da quantidade estequiométrica de água $1,72 \%$ do peróxido de hidrogênio adicionado não reagiu e manteve-se na solução. Operando com apenas $150 \%$ da quantidade estequiométrica de água não foi possível identificar peróxido de hidrogênio residual. Portanto, pode-se concluir que na condição operacional de $12,5{ }^{\circ} \mathrm{C}$ a água em excesso presente em solução proporcionou condições que favoreceram a conservação do peróxido de hidrogênio em solução e assim uma melhor conversão com uma menor quantidade de peróxido de hidrogênio adicionado.

Operando a $22,5^{\circ} \mathrm{C}$, observa-se que a conversão na condição de diluição com $150 \%$ da quantidade estequiométrica de água, mantém-se superior à de maior diluição independentemente da quantidade de agente oxidante adicionado. Este comportamento indica que operando nesta condição de temperatura, 22,5 ${ }^{\circ} \mathrm{C}$, a maior condição de diluição demonstrou ser prejudicial para o processo. Como visto na análise anterior, a temperatura do meio promoveu de forma parcial a inibição do processo de auto decomposição térmica e a o meio diluído agiu como dispersor da matéria, dificultando o encontro de ferro com o peróxido de hidrogênio e assim aumentando a probabilidade de auto decomposição do mesmo. A análises para a quantificação do peróxido de hidrogênio residual não identificaram a presença de peróxido de hidrogênio nas soluções ao fim da reação. 


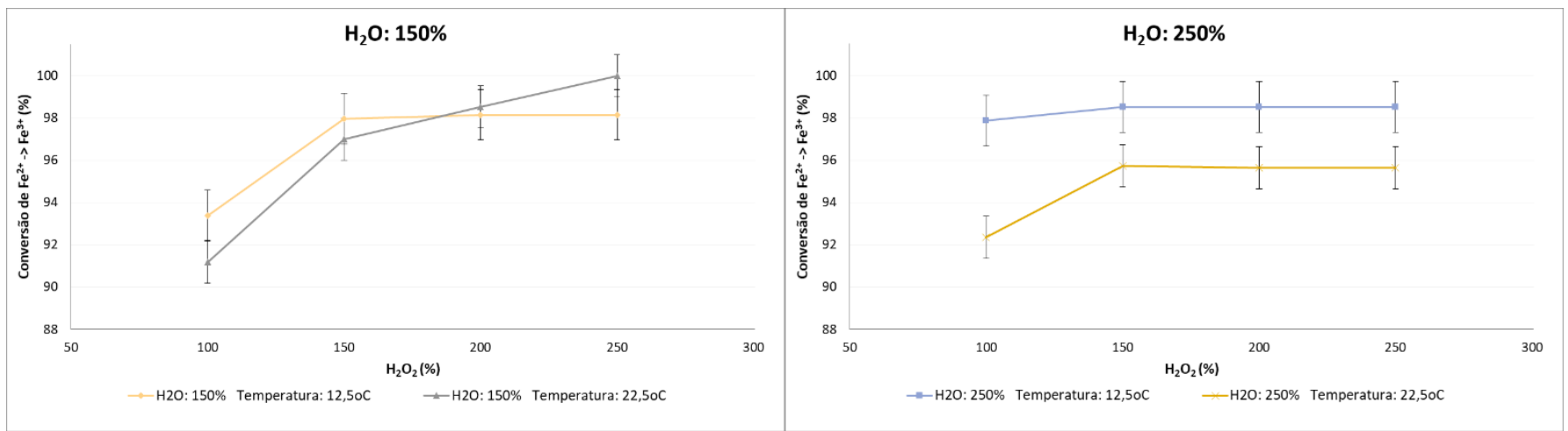

Figura 20 - Perfil de conversão de $\mathrm{Fe}^{+2}$ em Fe ${ }^{+3}$ na condição operacional de igual diluição ( $150 \%$ e $250 \%$ de água) em diferentes temperaturas de operação $\left(12,5^{\circ} \mathrm{C}\right.$ e $\left.22,5^{\circ} \mathrm{C}\right)$

( ${ }^{*} \mathrm{H}_{2} \mathrm{O}_{2}$ e $\mathrm{H}_{2} \mathrm{O}$ em \% referentes às suas respectivas quantidades estequiométricas

Analisando o gráficos contido na Figura 20, onde a diluição equivale a $150 \%$ da quantidade estequiométrica de água, observa-se que operando com esta quantidade de água não é vantajoso resfriar a solução a $12,5^{\circ} \mathrm{C}$, visto que não foram produzidos ganhos significativos para a conversão comparado a operação a $22,5{ }^{\circ} \mathrm{C}$. Em ambas as condições, não foi possível identificar peróxido de hidrogênio residual.

O perfil de convesão na Figura 20 para diluições contendo $250 \%$ da quantidade estequiométrica de água corrobora para as análises anteriores onde observou-se que a condição operacional de grande diluição em altas temperaturas promove um meio para a decomposição térmica do peróxido de hidrogênio, prejudicando a sua aplicação como agente oxidante. Na condição de temperatura igual a $12,5^{\circ} \mathrm{C}$ foi identificado que $1,72 \%$ de peróxido de hidrogênio não reagiu e na temperatura de $22,5{ }^{\circ} \mathrm{C}$ não foi identificado a presença de peróxido de hidrogênio residual.

\section{4.}

\section{Análise da conversão de $\mathrm{Fe}^{2+}$ em $\mathrm{Fe}^{3+}$ e do potencial de redução em função da quantidade de peróxido de hidrogênio}

A Figura 21 apresenta os gráficos de cada meio reacional, diferenciando-os pela quantidade de $\mathrm{H}_{2} \mathrm{O}$ adicionada e pela temperatura imposta. Este conjunto de gráficos exprime o comportamento do potencial de redução (Eh) do meio reacional e da conversão, ambos em função da quantidade de peróxido de hidrogênio adicionado ao meio. 
Os potenciais de redução foram corrigidos pela adição de $194 \mathrm{mV}$ ao valor observado.

A análise da Figura 21 expõe que há uma relação de concordância entre o aumento do potencial redução do meio e o percentual de $\mathrm{Fe}^{2+}$ convertido e, portanto, a promoção de um meio contendo em maior quantidade a espécie $\mathrm{Fe}^{3+}$.

É possível observar que em todos os perfis de conversão de $\mathrm{Fe}^{2+}$ em $\mathrm{Fe}^{3+}$, exibidos na Figura 21, a partir do ponto onde atinge-se o valor máximo medido do potencial eletroquímico da solução ocorre a estabilização ou um pequeno aumento do percentual convertido. Em quase todos os ensaios nota-se que com a adição de $150 \%$ da quantidade estequiométrica de $\mathrm{H}_{2} \mathrm{O}_{2}$ atinge-se o valor máximo medido para o potencial eletroquímico das soluções. Apenas para o ensaio na condição de $150 \%$ da quantidade estequiométrica de água e temperatura de operação igual a $12,5^{\circ} \mathrm{C}$, Figura 21 letra (b), atinge-se o valor máximo medido para o potencial eletroquímico das soluções com a adição de $100 \%$ da quantidade estequiométrica de $\mathrm{H}_{2} \mathrm{O}_{2}$.

O comportamento observado, onde o pico de maior potencial de redução coincide com o momento no qual obtém-se percentuais de conversão estáveis ou que sofrem pouca alteração de aumento, é esperado visto que na faixa de $\mathrm{pH}$ do meio reacional a qual todos os diferentes ensaios se encontravam, quanto maior o potencial observado maior é a concentração de $\mathrm{Fe}^{3+}$. O diagrama de Pourbaix que relaciona a proporção de espécies será demonstrado mais à frente.

Outro fenômeno é observado após a identificação do pico de maior potencial de redução. É possível notar que em todos os ensaios, apesar das diferentes condições de temperatura e diluição impostas ao meio reacional, após a obtenção do valor máximo de potencial eletroquímico ocorre uma leve queda no potencial de redução ocasionado pelas adições seguintes de $\mathrm{H}_{2} \mathrm{O}_{2}$. 


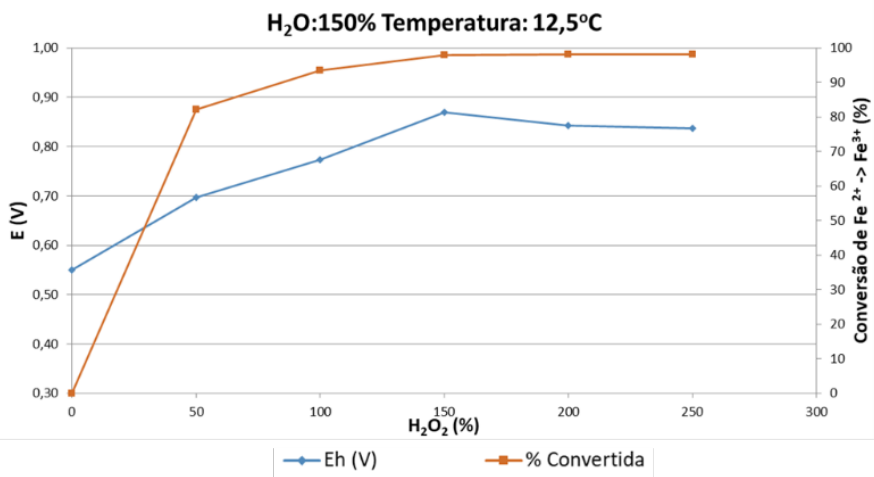

(a)

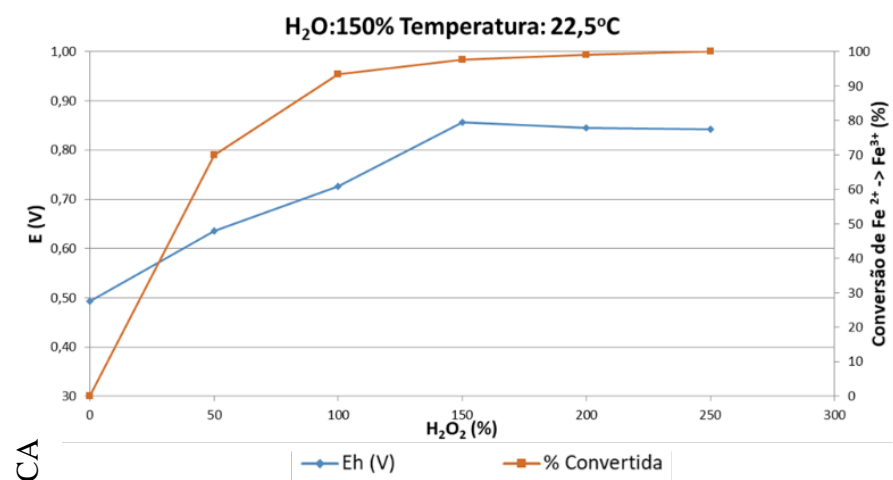

(c)

$\mathrm{H}_{2} \mathrm{O}: 100 \%$ Temperatura: $17,5^{\circ} \mathrm{C}$

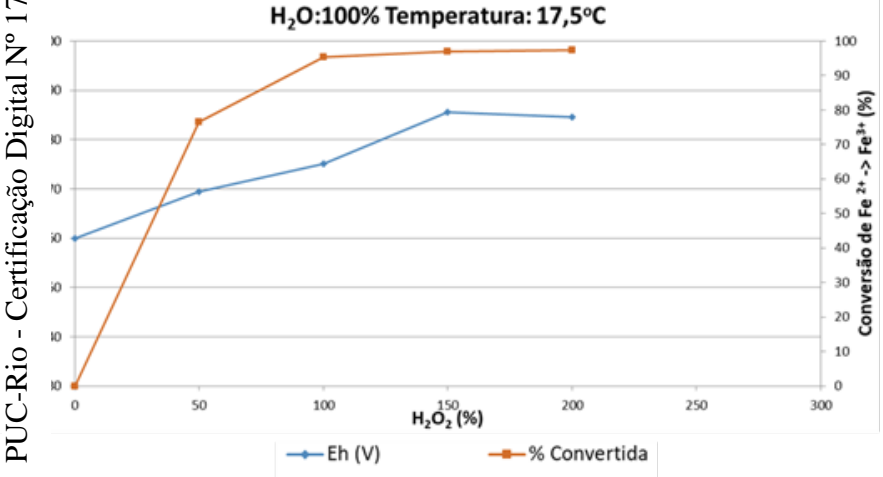

(e )

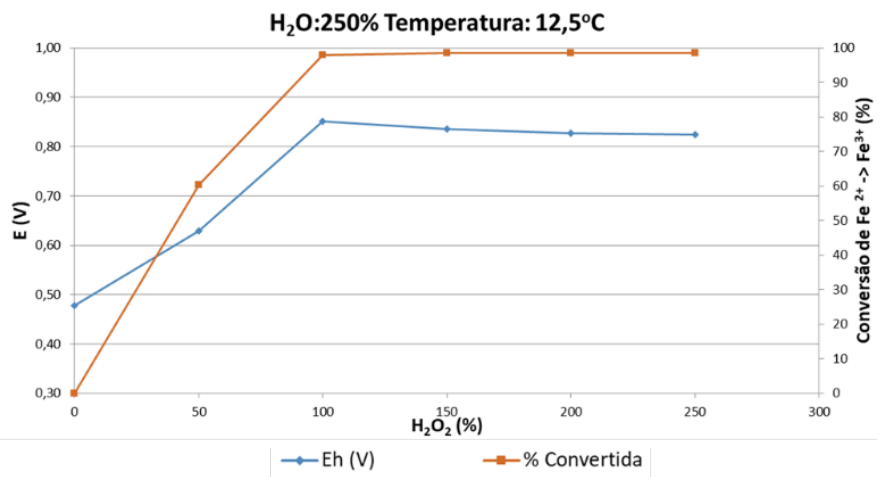

(b)

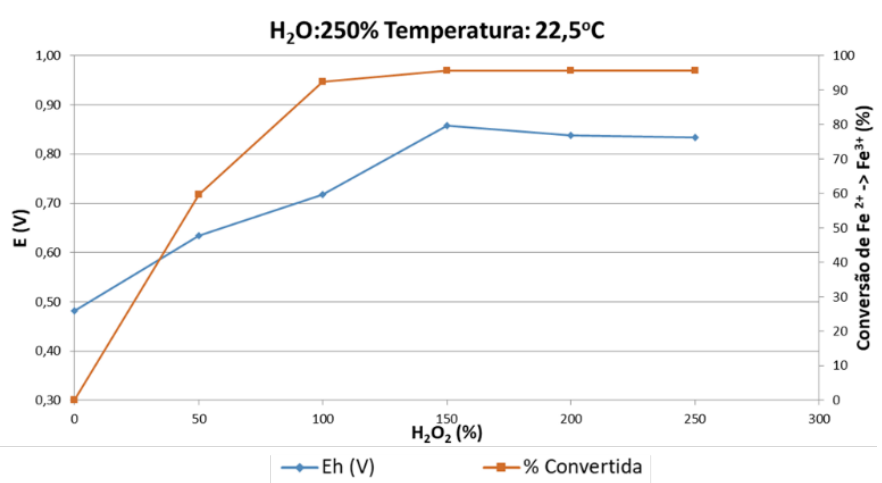

(d)

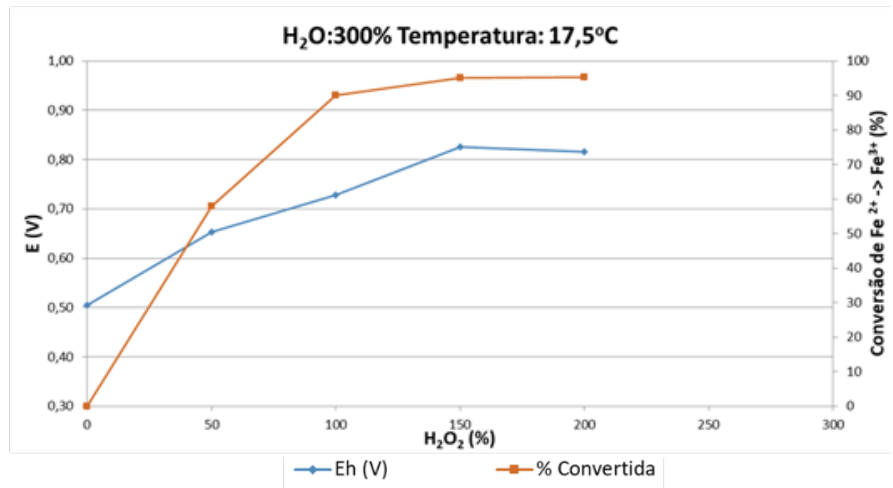

(f) 


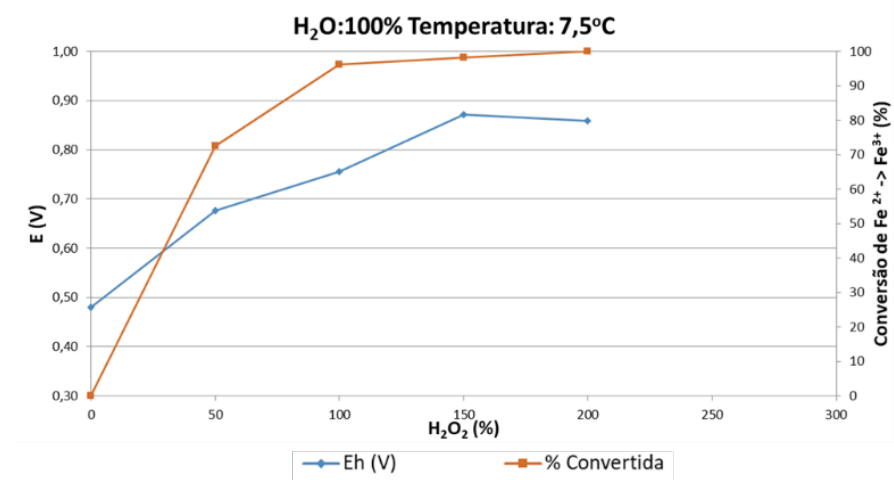

( g )

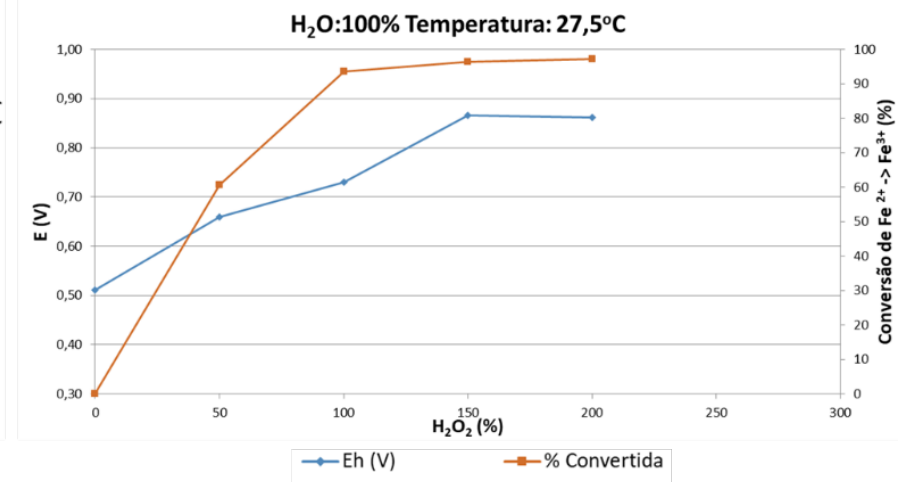

( h )

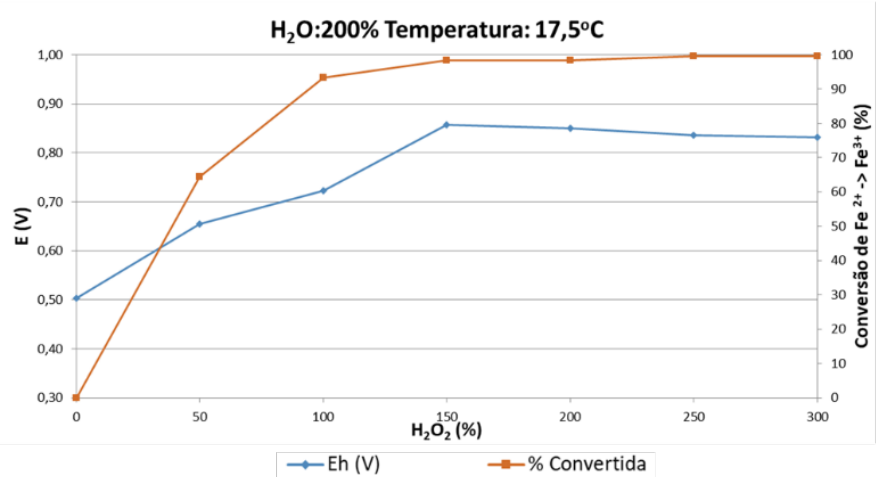

(i )

gura 21 - Conversão de $\mathrm{Fe}^{+2}$ em Fe $\mathrm{Fe}^{+3}$ e potencial de redução em função da quantidade adicionada de peróxido 3 hidrogênio nas diferentes condições experimentais

$\mathrm{H}_{2} \mathrm{O}_{2}$ e $\mathrm{H}_{2} \mathrm{O}$ em \% referentes às suas respectivas quantidades estequiométricas

\section{5 .}

Análise do perfil de potencial de oxirredução (Eh) e diagrama de Pourbaix

O diagrama de Pourbaix representa graficamente a relação entre o potencial eletroquímico de equilíbrio (Eh) considerando as possíveis diferentes espécies aquosas e precipitadas de um determinado metal, em função do pH da solução.

Visando a analisar as espécies em equilíbrio presentes no sistema estudado, utilizou-se o software Medusa para gerar um diagrama de Pourbaix dentro das condições do sistema reacional estudado no presente trabalho, apresentado na Figura 22. 
$\left[\mathrm{Fe}^{3+}\right]_{\mathrm{TOT}}=3.00 \mathrm{M} \quad\left[\mathrm{SO}_{4}{ }^{2-}\right]_{\mathrm{TOT}}=4.50 \mathrm{M}$

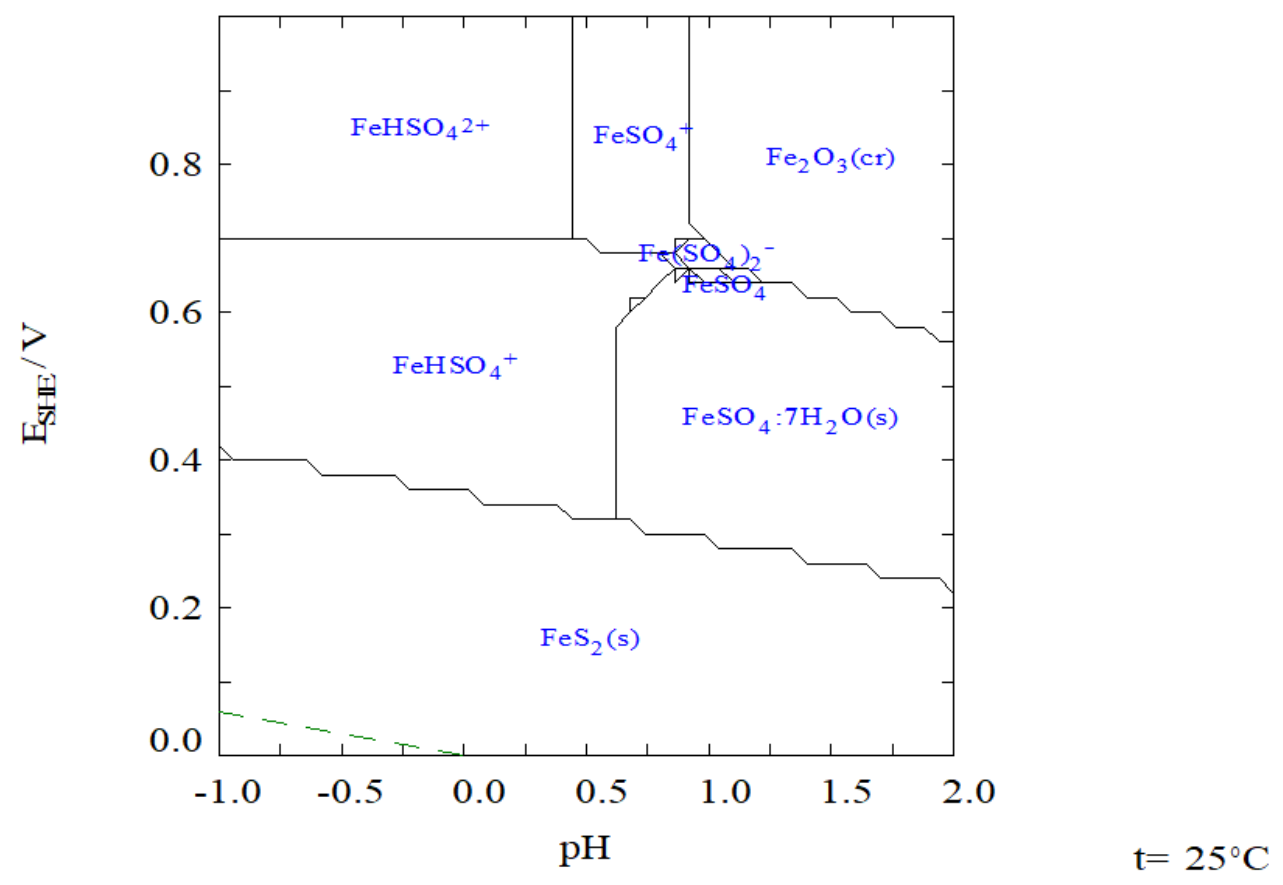

Figura 22 - Diagrama de Pourbaix para a família de espécies de Fe e S em água.

De acordo com o diagrama apresentado pela Figura 22 , na faixa de $\mathrm{pH}$ entre -1 e 1 com potencial de oxidação iguais ou maiores que $0,7 \mathrm{~V}$, tem-se predominantemente o $\mathrm{Fe}^{3+}$. Como apresentado no Anexo 9.4, o pH do meio estudado em todos os ensaios ao final dos experimentos ficou abaixo de 0,6.

A Figura 23 representa graficamente os dados coletados nos ensaios de $\mathrm{Eh}(\mathrm{v})$ versus a conversão, possibilitando a identificação visual de em qual a faixa de potenciais de redução ocorreram as maiores conversões. 


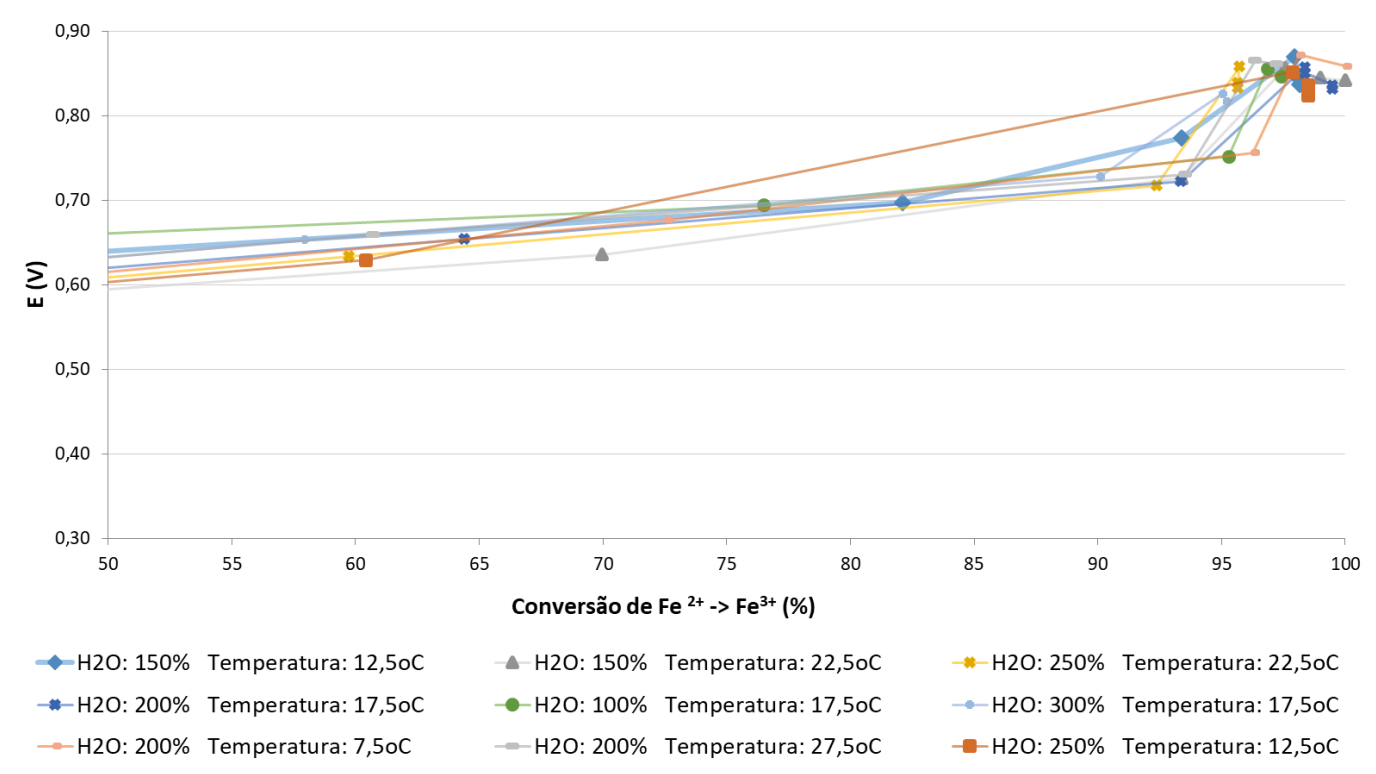

Figura $23-E_{h}(V)$ versus conversão em cada ensaio

${ }^{*} \mathrm{H}_{2} \mathrm{O}_{2}$ e $\mathrm{H}_{2} \mathrm{O}$ em \% referentes às suas respectivas quantidades estequiométricas

É possível observar, utilizando a Figura 23 , que conversões acima de $90 \%$ de $\mathrm{Fe}^{2+}$ em $\mathrm{Fe}^{3+}$ apresentaram potenciais de redução acima de 0,70 volts.

Portando, utilizando as observações obtidas pela análise da Figura 22 em conjunto com a Figura 23, podemos concluir que os dados obtidos indicavam corretamente uma maior presença de $\mathrm{Fe}^{3+}$ nos coagulantes produzidos e, portanto, que de fato o processo de oxidação possibilitou a conversões de grande parte do $\mathrm{Fe}^{2+}$ presente em solução. 


\section{6 \\ Conclusões}

- Foi possível otimizar o processo de produção de coagulante férrico a partir dos cristais de sulfato ferroso heptahidratado utilizando peróxido de hidrogênio como oxidante. Os critérios para a determinação do ponto ótimo, tendo como objetivo a produção de um coagulante dentro das normas regulamentadas foram: menor demanda de energia para o controle da temperatura, condições operacionais que propiciam uma elevada conversão de $\mathrm{Fe}^{2+}$ em $\mathrm{Fe}^{3+}$ em menor tempo para a reação, maior segurança para a aplicação deste processo em uma escala industrial e minimização da quantidade requerida de peróxido de hidrogênio (reagente de

maior

custo).

- A análise estatística conduziu ao estabelecimento de um modelo empírico de Conversão de $\mathrm{Fe}^{2+}$ em $\mathrm{Fe}^{3+}$ (\%) em função das variáveis independentes: $x 1=$ Quantidade de $\mathrm{H}_{2} \mathrm{O}_{2}$ (\% referente à sua quantidade estequiométrica); x2 = Quantidade de água (\% referente à sua quantidade estequiométrica); x3 = Faixa de temperatura, com a equação:

$$
\begin{gathered}
y=83+0,08431 \mathbf{x} 1-0,00016 \times \mathbf{1}^{2}+0,04929 \mathbf{x} 2+0,17234 \mathbf{x 3} \\
+0,01196 \mathbf{X 3}^{2}-0,00356 \mathbf{X} \mathbf{2} \mathbf{3}
\end{gathered}
$$

- As condições operacionais ótimas reveladas foram: $150 \%$ da quantidade estequiométrica de peróxido de hidrogênio (50\% de excesso), $200 \%$ da quantidade estequiométrica de água (100\% de excesso), quantidade estequiométrica de ácido sulfúrico e temperatura de $17,5^{\circ} \mathrm{C}$. Foi possível obter uma conversão de 96,17\% de $\mathrm{Fe}^{2+}$ em $\mathrm{Fe}^{3+}$, dentro das normas técnicas recomendadas para o produto como coagulante.

- As elevadas conversões com menores quantidades adicionadas de peróxido de hidrogênio quando em temperatura reacional baixa ( entre 7,5 ${ }^{\circ} \mathrm{C}$ e $17,5^{\circ} \mathrm{C}$ ) em conjunto com as análises feitas para a determinação de 
peróxido de hidrogênio residual e as observações visuais, corroboram para a suposição inicialmente feita, de que a baixa e controlada temperatura do processo contribuiriam para a difusão do peróxido de hidrogênio por todo o meio reacional e assim para o seu melhor aproveitamento na sua ação como oxidante, através do retardamento da sua auto decomposição térmica.

- Diferente da Patente US 4.707.349 na qual a o processo de adição de peróxido de hidrogênio ocorre a $50{ }^{\circ} \mathrm{C}$, em quantidade indeterminada e perdura por aproximadamente 3 horas, devido ao risco de explosão causado pela alta temperatura do meio reacional em conjunto com a exotermicidade do processo de oxidação, o processo de adição de peróxido de hidrogênio estudado no presente estudo em temperaturas abaixo de $30{ }^{\circ} \mathrm{C}$ demonstrou-se virtualmente instantâneo, requerendo menores quantidades de peróxido de oxigênio e seguro para aplicações industriais.

- O potencial de oxirredução mostrou-se um parâmetro útil para o controle do processo de conversão. Conversões acima de $90 \%$ de $\mathrm{Fe}^{2+}$ em $\mathrm{Fe}^{3+}$ apresentaram potenciais de redução correspondentes acima de 0,70 volts. 


\section{7 \\ Sugestões para trabalhos futuros}

- Empregar um equipamento capaz de permitir um controle de temperatura mais preciso durante o processo reacional e/ou estudar níveis de temperatura com menor proximidade entre as faixas (diferença entre níveis superior

a 5

$\left.{ }^{\circ} \mathrm{C}\right)$.

- Estudar a influência de temperaturas superiores a $27,5^{\circ} \mathrm{C}$ no processo de conversão de $\mathrm{Fe}^{2+}$ em $\mathrm{Fe}^{3+}$, com o objetivo de aumentar a sensibilidade do comportamento de conversão em função da temperatura.

- Utilização de técnicas de análise que requeiram menores diluições.

- Realizar análise econômica do processo em condições de temperatura controlada.

- Realizar um estudo termodinâmico e cinético das reações envolvidas no processo de conversão de $\mathrm{Fe}^{2+}$ em $\mathrm{Fe}^{3+}$, através da adição de peróxido de hidrogênio em meio contendo ácido sulfúrico.

- Construção de uma planta piloto do processo de conversão de $\mathrm{Fe}^{2+}$ em $\mathrm{Fe}^{3+}$, através da adição de peróxido de hidrogênio e em temperatura controlada, para avaliação da aplicação do processo em escala industrial. 
8

\section{Referências bibliográfica}

1. WORLD HEALTH ORGANIZATION. Guidelines for drinking-water quality. World Health Organization, 2004.

2. WORLD HEALTH ORGANIZATION et al. Progress on household drinking water, sanitation and hygiene 2000-2017: special focus on inequalities. New York: United Nations Children's Fund (UNICEF) and World Health Organization (WHO), 2019.

3. CORCORAN, E... Sick water?: the central role of wastewater management in sustainable development: a rapid response assessment. UNEP/Earthprint, 2010.

4. BRASIL. MINISTÉRIO DA SAÚDE. FUNDAÇÃO NACIONAL DE SAÚDE.. Manual de controle da qualidade da água para técnicos que trabalham em ETAS. 2014.

5. MACKENZIE, L. D.. Tratamento de águas para abastecimento e residuárias: princípios e práticas. 1 ed, Rio de Janeiro: Elsevier, 2017.

6. SECKLER, S.. Tratamento de Água: Concepção, Projeto e Operação de Estações de Tratamento - Um Guia Prático para Alunos e Profissionais. Elsevier Brasil, 2017.

7. DE SOUZA, W. A.. Tratamento de Água. Natal : CEFET - RN, 2007.

8. BRASIL. CONSELHO NACIONAL DO MEIO AMBIENTE (CONAMA). Resolução CONAMA n 430/2011. Diário Oficial da União, 2011.

9. BRASIL. MINISTÉRIO DA SAÚDE. Portaria $\mathbf{n}^{\circ}$ 2.914, de 12 de dezembro de 2011. Diário Oficial da União, n. 239, 2011.

10. BRATBY, J.. Coagulation and flocculation with an emphasis on water and wastewater treatment. Coydon: Uplands Press Ltd., 1980.

11. ZETA-METER, INC.. Everything you want to know about Coagulation \& Flocculation. 4. ed. Staunton, 1993.

12. BINNIE, C.; KIMBER, M.; SMETHURST, G.. Basic Water Treatment. 3.ed. Royal Society of Chemistry, 2002.

13. RICHTER, C. A.. Água Métodos e Tecnologia de Tratamentos. Blucher, 2009. 
14. SAWYER, C. N.; MCCARTY, PERRY L.. Chemistry For Environmental Engineering And Science. New York: McGraw-Hill Companies,Inc., 2003.

15. MASSCHELEIDEN, W .J.. Unit Processes In Drinking Water Treatment. New York : Marcel Dekker, 1992..

16. JÚNIOR, L.; ABREU, F. O. M. S.. Produtos naturais utilizados como coagulantes e floculantes para tratamento de águas: uma revisão sobre benefícios e potencialidades. Revista Virtual de Química, v. 10, n. 3, 2018.

17. MENEZES, J. C. S. S. Produção de Coagulantes Férricos na Mineração de Carvão. Tese de doutorado. Universidade Federal do Rio Grande do Sul, 2009

18. ABIQUIM. Manual de Gestão Eficiente de Recursos Hídricos. São Paulo, 2016.

19. TZOUPANOS, N. D.; ZOUBOULIS, A. I.. Coagulation-flocculation processes in water/wastewater treatment: the application of new generation of chemical reagents. 6th IASME/WSEAS International Conference on Heat Transfer, Thermal Engineering and Environment (HTE'08). pp. 309-317. Rhodes, 2008.

20. PAVANELLI, G.. Eficiência de diferentes tipos de coagulantes na coagulação, floculação e sedimentação de água com cor ou turbidez elevada. 2001. Tese de Doutorado. Universidade de São Paulo.

21. GEBBIE, P.. An operator's guide to water treatment coagulants. 31st Annual QId Water Industry Workshop-Operations Skills, University Central Queensland, Rockhampton, Australia. 2006. p. 4-6.

22. ROSA, A. H.; FRACETO, L. F.; MOSCHINI-CARLOS, V.. Meio Ambiente e Sustentabilidade. Porto Alegre: Bookman Companhia Editora Ltda., 2012.

23. LEWIS SR, R. J.; LEWIS, R. A.; HAWLEY, G. G.. Hawley's condensed chemical dictionary. John Wiley \& Sons, 2016.

24. GREENE, S. A.; POHANISH, R. P.. Sittig's Handbook of Pesticides and Agricultural Chemicals. William Andrew, 2005.

25. QuimiTecnica. Sulfato férrico. Disponível em: < https://www.quimitecnica.com/produto/sulfato-ferrico>. Acesso em: 20 fev. 2018. 
26. CHEREMISINOFF, N. P.; DAVLETSHIN, A... Hydraulic fracturing operations: handbook of environmental management practices. John Wiley \& Sons, 2015.

27. AMERICAN WATER WORKS ASSOCIATION et al. Standard for Ferric Sulfate. American Water Works Association, Denver, 1998

28. HORNE, R. L.. Process for the manufacturing of ferric sulfate. US Patent n. 8,658,124, Estados Unidos da América, 25 de fev, 2014.

29. HJERSTED, N. B. Process of preparing a preferred ferric sulfate solution, and product. U.S. Patent n. 4,707,349, Estados Unidos da América, 17 nov. 1987.

30. RAO, S. R. et al.. Acid mine drainage as a coagulant. Minerals Engineering, v. 5, n. 9, p. 1011-1020, 1992.

31. SILVA, R. A.. Recuperação hidrometalúrgica de metais da drenagem ácida de minas por precipitação seletiva. Tese de doutorado. Universidade Federal do Rio Grande do Sul, 2010.

32. VILLETTI, P. I. C.. Produção de coagulante férrico a partir da lixiviação de concentrado de pirita da mineração de carvão via cristalização/solubilização de sulfato ferroso: estudo comparativo entre rejeitos de duas jazidas. Tese de doutorado. Universidade Federal do Rio Grande do Sul, 2017.

33. ROCKETDYNE. Hydrogen Peroxide Handbook. California : Air Force Rocket Propulsion Laboratory, 1967.

34. GOOR, G.. Hydrogen peroxide: manufacture and industrial use for production of organic chemicals. Catalytic Oxidations with Hydrogen Peroxide as Oxidant. Springer, Dordrecht, 1992. p. 13-43.

35. MATTOS, I. L., et al.. Peróxido de hidrogênio: importância e determinação. 373-380, Química nova, p. 373-380, 2003.

36. ARKEMA. Hydrogen Peroxide. Disponível em: <www.arkemagroup.com>. Acesso em: 20 de fev. 2019.

37. YAZICI, E. Y.; DEVECI, H. Factors affecting decomposition of hydrogen peroxide. XIIth International Mineral Processing Symposium, Cappadocia, Turkey. p. 6-10, 2010.

38. PĘDZIWIATR, P., et al.. Decomposition of hydrogen peroxide: kinetics and review of chosen catalysts. Acta Innovations, n. 26, p. 45-52, 2018.

39. DUNFORD, H. B.. Oxidations of iron (II)/(III) by hydrogen peroxide: from aquo to enzyme. Coordination Chemistry Reviews, v. 233, p. 311 318, 2002. 
40. KLAIS, O.. Hydrogen peroxide decomposition in the presence of organic material: a case study. Thermochimica acta, v. 225, n. 2, p. 213222, 1993.

41. HAAS, T. W.. Kinetics of the uncatalyzed, alkaline decomposition of hydrogen peroxide. 1960.

42. PHONG, M. T.; AIRES, C. B.. Experimental and theoretical analysis of a critical chemical reaction: decomposition of hydrogen peroxide. Science \& Technology Development, 30, 2008.

43. BUXTON, G. V. et al.. Critical review of rate constants for reactions of hydrated electrons, hydrogen atoms and hydroxyl radicals $\left(\cdot \mathrm{OH} / \mathrm{O}^{-}\right)$ in aqueous solution. Journal of Physical and Chemical Reference Data, v. 17, n. 2, p. 513-886, 1988.

44. NOGUEIRA, R. F. P. et al. Fundamentos e aplicações ambientais dos processos Fenton e foto-Fenton. Química nova, p. 400-408, 2007.

45. LE TRUONG, G.; DE LAAT, J.; LEGUBE, B.. Effects of chloride and sulfate on the rate of oxidation of ferrous ion by $\mathrm{H} 2 \mathrm{O} 2$. Water research, v. 38, n. 9, p. 2384-2394, 2004.

46. ROSS, A. B.; NETA, P.. Rate constants for reactions of inorganic radicals in aqueous solution. Washington D. C: US Department of Commerce, National Bureau of Standards, 1979.

47. RODRIGUES, M. I.; IEMMA, A. F.. Planejamento de experimentos e otimização de processos. 3. ed. Campinas: Cárita Editora Espirita, 2014.

48. MONTGOMERY, D. C.. Design and Analysis of Experiments. 8. ed. John Wiley \& Sons, Inc., 2013.

49. AMERICAN PUBLIC HEALTH ASSOCIATION et al.. Standard methods for the examination of water and wastewater. American Public Health Association., 1915.

50. CSM PRODUTOS QUÍMICOS. Sulfato férrico. Disponível em: <http://csmpq.com.br/produtos/sulfato-ferrico-liquido-42>. Acesso em: 20 jun. 2018.

51. THOMAS, R. L.. Introductory econometrics. London: Longman, 1993.

52. FLEMING, M. C.; NELLIS, J. G.. Principles of applied statistics: an integrated approach using MINITAB and Excel. Cengage Learning EMEA, 2000.

53. LIN, S.; GUROL; M. D.. Catalytic decomposition of hydrogen peroxide on iron oxide: kinetics, mechanism, and implications. Environmental Science \& Technology, v. 32, n. 10, p. 1417-1423, 1998. 
9

Anexos

9.1.

Reações envolvidas na decomposição catalisada por metais

Observação: Em condições normais de operação, o fenômeno da recombinação do radical hidroxila pode ser ignorado devido à baixa concentração deste radical, aproximadamente $10^{-1} \mathrm{M}(27)$ (53).

$$
\begin{aligned}
& \mathrm{M}^{2+}+\mathrm{H}_{2} \mathrm{O}_{2} \rightarrow \mathrm{M}^{3+}+\mathrm{OH}^{-}+\cdot \mathrm{OH} \\
& \mathrm{M}^{2+}+\cdot \mathrm{OH} \rightarrow \mathrm{M}^{3+}+\mathrm{OH}^{-} \\
& \cdot \mathrm{OH}+\mathrm{H}_{2} \mathrm{O}_{2} \rightarrow \mathrm{H}_{2} \mathrm{O}+\cdot \mathrm{OOH} \\
& \cdot \mathrm{OOH}+\mathrm{H}_{2} \mathrm{O}_{2} \rightarrow \mathrm{H}_{2} \mathrm{O}+\mathrm{O}_{2}+\cdot \mathrm{OH} \\
& M^{3+}+\mathrm{H}_{2} \mathrm{O}_{2} \rightarrow \mathrm{M}^{2+}+\cdot \mathrm{OOH}+\mathrm{H}^{+} \\
& \cdot \mathrm{OOH}+\mathrm{H}_{2} \mathrm{O}_{2} \rightarrow \mathrm{O}_{2}^{-}+\mathrm{H}^{+} \\
& \mathrm{M}^{3+}+\mathrm{HO}_{2}{ }^{-} \rightarrow \mathrm{M}^{2+}+\cdot \mathrm{OOH} \\
& M^{3+}+\mathrm{H}_{2} \mathrm{O}_{2} \leftrightarrow M\left(\mathrm{HO}_{2}\right)^{2+}+\mathrm{H}^{+} \\
& M\left(\mathrm{HO}_{2}\right)^{2+} \rightarrow \mathrm{M}^{2+}+\cdot \mathrm{OOH} \\
& \mathrm{H}_{2} \mathrm{O}_{2}+\cdot \mathrm{O}_{2}^{-} \rightarrow \cdot \mathrm{OH}+\mathrm{OH}^{-}+\mathrm{O}_{2} \\
& \cdot \mathrm{OH}+\cdot \mathrm{OH} \rightarrow \mathrm{H}_{2} \mathrm{O}_{2} \\
& \cdot \mathrm{OH}+\mathrm{H}_{2} \mathrm{O}_{2} \rightarrow \cdot \mathrm{OOH}+\mathrm{H}_{2} \mathrm{O} \\
& \mathrm{M}^{2+}+\cdot \mathrm{OOH}+\mathrm{H}^{+} \rightarrow \mathrm{M}^{3+}+\mathrm{H}_{2} \mathrm{O}_{2} \\
& \mathrm{M}^{3+}+\cdot \mathrm{OOH} \rightarrow \mathrm{H}^{+}+\mathrm{M}^{2+}+\mathrm{H}_{2} \mathrm{O}_{2}
\end{aligned}
$$




\section{2.}

Respostas obtidas pelo software Statistica

\subsection{1.}

Estimação dos Efeitos, incluindo todas as variáveis estudadas

\begin{tabular}{|c|c|c|c|c|c|c|c|c|c|c|}
\hline Factor & Effect & Std.Err. & $t(7)$ & $p$ & $\begin{array}{c}-90, \% \\
\text { Cnf.Limt }\end{array}$ & $\begin{array}{c}+90, \% \\
\text { Cnf.Limt }\end{array}$ & Coeff. & $\begin{array}{l}\text { Std.Err. } \\
\text { Coeff. }\end{array}$ & $\begin{array}{c}-90, \% \\
\text { Cnf.Limt }\end{array}$ & $\begin{array}{c}+90, \% \\
\text { Cnf.Limt }\end{array}$ \\
\hline Mean/Interc. & 98.02967 & 0,835369 & 117,3489 & 0,000000 & 96,44699 & 99,61234 & 98,02967 & 0,835369 & 96,44699 & 99,61234 \\
\hline (1) $\mathrm{H}_{2} \mathrm{O}_{2}(\mathrm{~L})$ & 2,16558 & 0,785052 & 2,7585 & 0,028156 & 0,67824 & 3,65292 & 1,08279 & 0,392526 & 0,33912 & 1,82646 \\
\hline $\mathrm{H}_{2} \mathrm{O}_{2}(\mathrm{Q})$ & $-1,21603$ & 0,864874 & $-1,4060$ & 0,202522 & $-2,85460$ & 0,42254 & $-0,60801$ & 0,432437 & $-1,42730$ & 0,21127 \\
\hline (2) $\mathrm{H}_{2} \mathrm{O}(\mathrm{L})$ & $-1,41301$ & 0,785052 & $-1,7999$ & 0,114902 & $-2,90035$ & 0,07433 & $-0,70651$ & 0,392526 & $-1,45018$ & 0,03717 \\
\hline $\mathrm{H}_{2} \mathrm{O}(\mathrm{Q})$ & $-0,73971$ & 0,864874 & $-0,8553$ & 0,420700 & $-2,37829$ & 0,89886 & $-0,36986$ & 0,432437 & $-1,18914$ & 0,44943 \\
\hline (3)Temperatura(L) & $-1,30003$ & 0,785052 & $-1,6560$ & 0,141697 & $-2,78737$ & 0,18731 & $-0,65001$ & 0,392526 & $-1,39369$ & 0,09366 \\
\hline Temperatura(Q) & 0,74586 & 0,864874 & 0,8624 & 0,417036 & $-0,89271$ & 2,38443 & 0,37293 & 0,432437 & $-0,44636$ & 1,19221 \\
\hline $1 \mathrm{~L}$ by $2 \mathrm{~L}$ & $-0,67603$ & 1,025267 & $-0,6594$ & 0,530746 & $-2,61848$ & 1,26642 & $-0,33801$ & 0,512633 & $-1,30924$ & 0,63321 \\
\hline $1 \mathrm{~L}$ by $3 \mathrm{~L}$ & & & & & $-1,40811$ & 2,47679 & & 0,512633 & $-0,70405$ & 1,23840 \\
\hline $2 \mathrm{~L}$ by $3 \mathrm{~L}$ & $-1,78198$ & 1,025267 & $-1,7381$ & 0,125763 & $-3,72443$ & 0,16047 & $-0,89099$ & 0,512633 & $-1,86222$ & 0,08023 \\
\hline
\end{tabular}

Figura 24 - Perfil dos efeitos todos os fatores

\begin{tabular}{|c|c|c|c|c|c|c|c|c|c|c|}
\hline Factor & Effect & Std.Err. & $t(8)$ & $p$ & $\begin{array}{c}-90, \% \\
\text { Cnf.Limt }\end{array}$ & $\begin{array}{c}+90, \% \\
\text { Cnf.Limt }\end{array}$ & Coeff. & $\begin{array}{l}\text { Std.Err. } \\
\text { Coeff. }\end{array}$ & $\begin{array}{c}-90, \% \\
\text { Cnf.Limt }\end{array}$ & $\begin{array}{c}+90, \% \\
\text { Cnf.Limt }\end{array}$ \\
\hline Mean/Interc. & 98,02967 & 0,796433 & 123,0859 & 0,000000 & 96,54866 & 99,51067 & 98,02967 & 0,796433 & 96,54866 & 99,51067 \\
\hline (1) $\mathrm{H}_{2} \mathrm{O}_{2}(\mathrm{~L})$ & 2,16558 & 0,748461 & 2,8934 & 0,020095 & 0,77378 & 3,55738 & 1,08279 & 0,374230 & 0,38689 & 1,77869 \\
\hline $\mathrm{H}_{2} \mathrm{O}_{2}(\mathrm{Q})$ & 1,21603 & 0,824562 & $-1,4748$ & , 178511 & $-2,74934$ & 0,31729 & $-0,60801$ & 0,412281 & $-1,37467$ & 0,15864 \\
\hline (2) $\mathrm{H}_{2} \mathrm{O}(\mathrm{L})$ & $-1,41301$ & 0,748461 & $-1,8879$ & 0,095736 & $-2,80481$ & $-0,02121$ & $-0,70651$ & 0,374230 & $-1,40241$ & $-0,01061$ \\
\hline $\mathrm{H}_{2} \mathrm{O}(\mathrm{Q})$ & $-0,73971$ & 0,824562 & $-0,8971$ & 0,395860 & $-2,27303$ & 0,79360 & $-0,36986$ & 0,412281 & $-1,13651$ & 0,39680 \\
\hline (3)Temp & & 748461 & & & $-2,69183$ & 0,09177 & 5001 & 0,374230 & $-1,34591$ & 0,04589 \\
\hline Temperat & & 824562 & & & $-0,78746$ & 2,27917 & & 0,412281 & $-0,39373$ & 1,13959 \\
\hline $1 \mathrm{~L}$ by $2 \mathrm{~L}$ & $-0,67603$ & 0,977479 & $-0,6916$ & 0,508757 & $-2,49370$ & 1,14164 & $-0,33801$ & 0,488740 & $-1,24685$ & 0,57082 \\
\hline $2 \mathrm{~L}$ by $3 \mathrm{~L}$ & $-1,78198$ & 0,977479 & $-1,8230$ & 0,105759 & $-3,59965$ & 0,03569 & $-0,89099$ & 0,488740 & $-1,79983$ & 0,01784 \\
\hline
\end{tabular}

Figura 25 - Perfil dos efeitos com retirada do fator de interação H2O2(L)xTemp. (L)

\begin{tabular}{|c|c|c|c|c|c|c|c|c|c|c|}
\hline Factor & Effect & Std.Err. & $t(9)$ & $p$ & $\begin{array}{c}-90, \% \\
\text { Cnf.Limt }\end{array}$ & $\begin{array}{l}+90, \% \\
\text { Cnf.Limt }\end{array}$ & Coeff. & $\begin{array}{l}\text { Std.Err. } \\
\text { Coeff. }\end{array}$ & $\begin{array}{c}-90, \% \\
\text { Cnf.Limt }\end{array}$ & $\begin{array}{c}+90, \% \\
\text { Cnf.Limt }\end{array}$ \\
\hline Mean/Interc. & 98,02967 & 0,773006 & 126,8162 & 0,000000 & 96,61266 & 99,44667 & 98,02967 & 0,773006 & 96,61266 & 99,44667 \\
\hline (1) $\mathrm{H}_{2} \mathrm{O}_{2}(\mathrm{~L})$ & 2,16558 & 0,726445 & 2,9811 & 0,015423 & 0,83393 & 3,49724 & 1,08279 & 0,363222 & 0,41696 & 1,74862 \\
\hline $\mathrm{H}_{2} \mathrm{O}_{2}(\mathrm{Q})$ & $-1,21603$ & 0,800308 & $-1,5194$ & 0,162968 & $-2,68308$ & 0,25103 & $-0,60801$ & 0,400154 & $-1,34154$ & 0,12551 \\
\hline (2) $\mathrm{H}_{2} \mathrm{O}(\mathrm{L})$ & $-1,41301$ & 0,726445 & $-1,9451$ & 0,083621 & $-2,74467$ & $-0,08136$ & $-0,70651$ & 0,363222 & $-1,37233$ & $-0,04068$ \\
\hline $\mathrm{H}_{2} \mathrm{O}(\mathrm{Q})$ & $-0,73971$ & 0,800308 & $-0,9243$ & 0,379452 & $-2,20677$ & 0,72734 & $-0,36986$ & 0,400154 & $-1,10338$ & 0,36367 \\
\hline (3)Temperatura(L) & $-1,30003$ & 0,726445 & $-1,7896$ & 0,107143 & $-2,63168$ & 0,03163 & $-0,65001$ & 0,363222 & $-1,31584$ & 0,01581 \\
\hline Temperatura $(\mathrm{Q})$ & 0,74586 & 0,800308 & 0,9320 & 0,375679 & $-0,72120$ & 2,21291 & 0,37293 & 0,400154 & $-0,36060$ & 1,10646 \\
\hline $2 \mathrm{~L}$ by $3 \mathrm{~L}$ & $-1,78198$ & 0,948727 & $-1,8783$ & 0,093060 & $-3,52111$ & $-0,04286$ & $-0,89099$ & 0,474363 & $-1,76055$ & $-0,02143$ \\
\hline
\end{tabular}

Figura 26 - Perfil dos efeitos com retirada do fator de interação H2O2(L)xH2O(L)

\begin{tabular}{|c|c|c|c|c|c|c|c|c|c|c|}
\hline Factor & Effect & Std.Err. & $t(10)$ & $\mathrm{p}$ & $\begin{array}{c}-90 \% \% \\
\text { Cnf.Limt }\end{array}$ & $\begin{array}{c}+90, \% \\
\text { Cnf.Limt }\end{array}$ & Coeff. & $\begin{array}{l}\text { Std. Err. } \\
\text { Coeff. }\end{array}$ & $\begin{array}{c}-90, \% \\
\text { Cnf.Limt }\end{array}$ & $\begin{array}{c}+90, \% \\
\text { Cnf.Limt }\end{array}$ \\
\hline Mean/Interc. & 97.55804 & 0,576426 & 169,2464 & 0,000000 & 96,51330 & 98,60279 & 97,55804 & 0,576426 & 96,51330 & 98,60279 \\
\hline (1) $\mathrm{H}_{2} \mathrm{O}_{2}(\mathrm{~L})$ & 2,16558 & 0,721133 & 3,0030 & 0,013275 & 0,85855 & 3,47261 & 1,08279 & 0,360567 & 0,42928 & 1,73630 \\
\hline $\mathrm{H}_{2} \mathrm{O}_{2}(\mathrm{Q})$ & $-0,99829$ & 0,759261 & $-1,3148$ & 0,217922 & $-2,37442$ & 0,37784 & $-0,49915$ & 0,379630 & $-1,18721$ & 0,18892 \\
\hline (2) $\mathrm{H}_{2} \mathrm{O}(\mathrm{L})$ & $-1,41301$ & 0,721133 & $-1,9594$ & 0,078510 & $-2,72004$ & $-0,10599$ & $-0,70651$ & 0,360567 & $-1,36002$ & $-0,05299$ \\
\hline (3)Temperatura(L) & $-1,30003$ & 0,721133 & $-1,8028$ & 0,101595 & $-2,60705$ & 0,00700 & $-0,65001$ & 0,360567 & $-1,30353$ & 0,00350 \\
\hline Temperatura(Q) & 0,96359 & 0,759261 & 1,2691 & 0,233142 & $-0,41254$ & 2,33972 & 0,48180 & 0,379630 & $-0,20627$ & 1,16986 \\
\hline $2 \mathrm{~L}$ by $3 \mathrm{~L}$ & $-1,78198$ & 0,941790 & $-1,8921$ & 0,087754 & $-3,48894$ & $-0,07503$ & $-0,89099$ & 0,470895 & $-1,74447$ & $-0,03751$ \\
\hline
\end{tabular}

Figura 27 - Perfil dos efeitos com retirada do fator $\mathrm{H} 2 \mathrm{O}(\mathrm{Q})$ 


\begin{tabular}{|c|c|c|c|c|c|c|c|c|c|c|}
\hline Factor & Effect & Std. Err. & $\mathrm{t}(11)$ & $p$ & $\begin{array}{c}-90, \% \\
\text { Cnf.Limt }\end{array}$ & $\begin{array}{c}+90, \% \\
\text { Cnf.Limt } \\
\end{array}$ & Coeff. & $\begin{array}{l}\text { Std.Err. } \\
\text { Coeff. }\end{array}$ & $\begin{array}{c}-90, \% \\
\text { Cnf.Limt }\end{array}$ & $\begin{array}{c}+90, \% \\
\text { Cnf.Limt }\end{array}$ \\
\hline Mean/Interc. & 98.03269 & 0,450637 & 217,5427 & 0,000000 & 97,22340 & 98,84198 & 98,03269 & 0,450637 & 97,22340 & 98,84198 \\
\hline (1) $\mathrm{H}_{2} \mathrm{O}_{2}(\mathrm{~L})$ & 2,16558 & 0,740880 & 2,9230 & 0,013863 & 0,83505 & 3,49611 & 1,08279 & 0,370440 & 0,41752 & 1,74806 \\
\hline $\mathrm{H}_{2} \mathrm{O}_{2}(\mathrm{Q})$ & $-1,21742$ & 0,759613 & $-1,6027$ & 0,137307 & $-2,58160$ & 0,14675 & $-0,60871$ & 0,379807 & $-1,29080$ & 0,07338 \\
\hline$(2) \mathrm{H}_{2} \mathrm{O}(\mathrm{L})$ & $-1,41301$ & 0,740880 & $-1,9072$ & 0,082932 & $-2,74355$ & $-0,08248$ & $-0,70651$ & 0,370440 & $-1,37177$ & $-0,04124$ \\
\hline (3)Temperatura(L) & $-1,30003$ & 0,740880 & $-1,7547$ & 0,107084 & $-2,63056$ & 0,03051 & $-0,65001$ & 0,370440 & $-1,31528$ & 0,01525 \\
\hline $2 \mathrm{~L}$ by $3 \mathrm{~L}$ & $-1,78198$ & 0,967579 & $-1,8417$ & 0,092621 & $-3,51964$ & $-0,04432$ & $-0,89099$ & 0,483789 & $-1,75982$ & $-0,02216$ \\
\hline
\end{tabular}

Figura 28 - Perfil dos efeitos com retirada do fator Temperatura (Q)

\begin{tabular}{|c|c|c|c|c|c|c|c|c|c|c|}
\hline Factor & Effect & Std.Err. & $\mathrm{t}(12)$ & $p$ & $\begin{array}{c}-90, \% \\
\text { Cnf.Limt } \\
\end{array}$ & $\begin{array}{c}+90, \% \\
\text { Cnf.Limt }\end{array}$ & Coeff. & $\begin{array}{l}\text { Std.Err. } \\
\text { Coeff. }\end{array}$ & $\begin{array}{c}-90, \% \\
\text { Cnf.Limt }\end{array}$ & $\begin{array}{c}+90, \% \\
\text { Cnf.Limt }\end{array}$ \\
\hline Mean/Interc. & 97.54412 & 0,352902 & 276,4058 & 0,000000 & 96,91515 & 98,17309 & 97,54412 & 0,352902 & 96,91515 & 98,17309 \\
\hline (1) $\mathrm{H}_{2} \mathrm{O}_{2}(\mathrm{~L})$ & 2,16558 & 0,787816 & 2,7488 & 0,017640 & 0,76147 & 3,56970 & 1,08279 & 0,393908 & 0,38073 & 1,78485 \\
\hline (2) $\mathrm{H}_{2} \mathrm{O}(\mathrm{L})$ & $-1,41301$ & 0,787816 & $-1,7936$ & 0,098099 & $-2,81713$ & $-0,00890$ & $-0,70651$ & 0,393908 & $-1,40856$ & $-0,00445$ \\
\hline (3)Temperatura(L) & $-1,30003$ & 0,787816 & $-1,6502$ & 0,124819 & $-2,70414$ & 0,10409 & $-0,65001$ & 0,393908 & $-1,35207$ & 0,05204 \\
\hline $2 \mathrm{~L}$ by $3 \mathrm{~L}$ & $-1,78198$ & 1,028877 & $-1,7320$ & 0,108879 & $-3,61574$ & 0,05177 & $-0,89099$ & 0,514438 & $-1,80787$ & 0,02589 \\
\hline
\end{tabular}

Figura 29 - Perfil dos efeitos com retirada do fator $\mathrm{H} 2 \mathrm{O} 2(\mathrm{Q})$

\subsection{2.}

Regressão dos coeficientes - Variáveis não codificadas.

\begin{tabular}{|c|c|c|c|c|c|c|}
\hline actor & $\begin{array}{c}\text { Regressn } \\
\text { Coeff. }\end{array}$ & Std.Err. & $t(10)$ & $p$ & $\begin{array}{c}-90, \% \\
\text { Cnf.Limt }\end{array}$ & $\begin{array}{c}+90, \% \\
\text { Cnf.Limt }\end{array}$ \\
\hline Mean/Interc. & 83,00298 & 8,433651 & 9,84188 & 0,000002 & 67,71732 & 98,28865 \\
\hline (1) $\mathrm{H}_{2} \mathrm{O}_{2}(\mathrm{~L})$ & 0,08431 & 0,041557 & 2,02874 & 0,069952 & 0,00899 & 0,15963 \\
\hline $\mathrm{H}_{2} \mathrm{O}_{2}(\mathrm{Q})$ & $-0,00016$ & 0,000103 & $-1,53099$ & 0,156771 & $-0,00034$ & 0,00003 \\
\hline (2) $\mathrm{H}_{2} \mathrm{O}(\mathrm{L})$ & 04929 & 0,031066 & 1,58649 & 0,143 & $-0,00702$ & 0,10559 \\
\hline (3)Temperatura( & & & & & $-0,74150$ & 1,08618 \\
\hline & & & & & & \\
\hline $2 \mathrm{~L}$ by $3 \mathrm{~L}$ & $-0,00356$ & 0,001740 & $-2,04822$ & 0,067709 & $-0,00672$ & $-0,00041$ \\
\hline
\end{tabular}

Figura 30 - Perfil de regressão com os fatores significativos

\section{3.}

Fotos das soluções para verificação da estabilidade do produto.

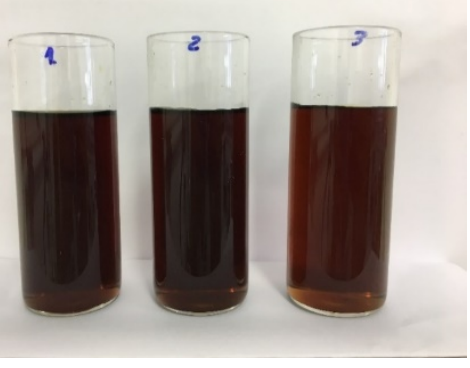

Figura 33 - Soluções coagulante referentes aos ensaios 1,2 e 3 .

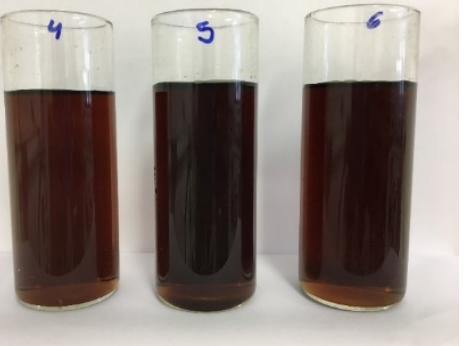

Figura 33 - Soluções coagulante Figura 33 - Soluções coagulante referentes aos ensaios 4, 5 e 6 . referentes aos ensaios 7,8 e 9 . 


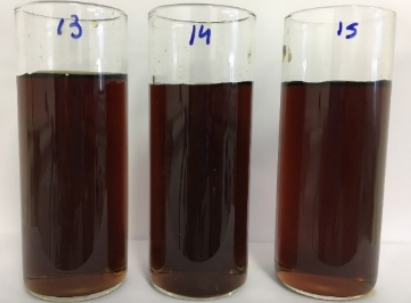

Figura 36 - Soluções coagulante referentes aos ensaios 13,14 e 15

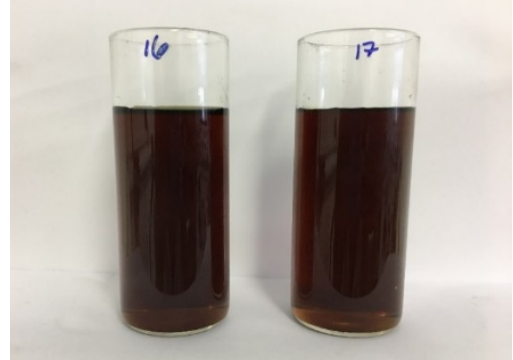

Figura 36 - Soluções coagulante referentes aos ensaios 16 e 17

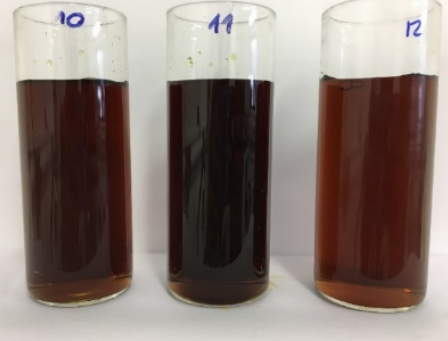

Figura 36 - Soluções coagulante referentes aos ensaios 10,11 e 12

\section{4.}

\section{pH final médio de cada ensaio.}

Tabela 22 - pH médio do coagulante ao final de cada ensaio

\begin{tabular}{cc} 
Ensaio & $\begin{array}{c}\text { pH do coagulante } \\
\text { produzido }\end{array}$ \\
1 & 0,027 \\
2 & 0,16 \\
3 & 0,43 \\
4 & 0,57 \\
5 & 0,15 \\
6 & 0,23 \\
7 & 0,35 \\
8 & 0,43 \\
9 & 0,31 \\
10 & 0,40 \\
11 & 0,36 \\
12 & 0,25 \\
13 & 0,34 \\
14 & 0,32 \\
$15 / 16 / 17$ & 0,36 \\
& \\
\hline
\end{tabular}

